\title{
Regional Strategy for Implementing the Code of Practice for Forest Harvesting in Asia-Pacific
}

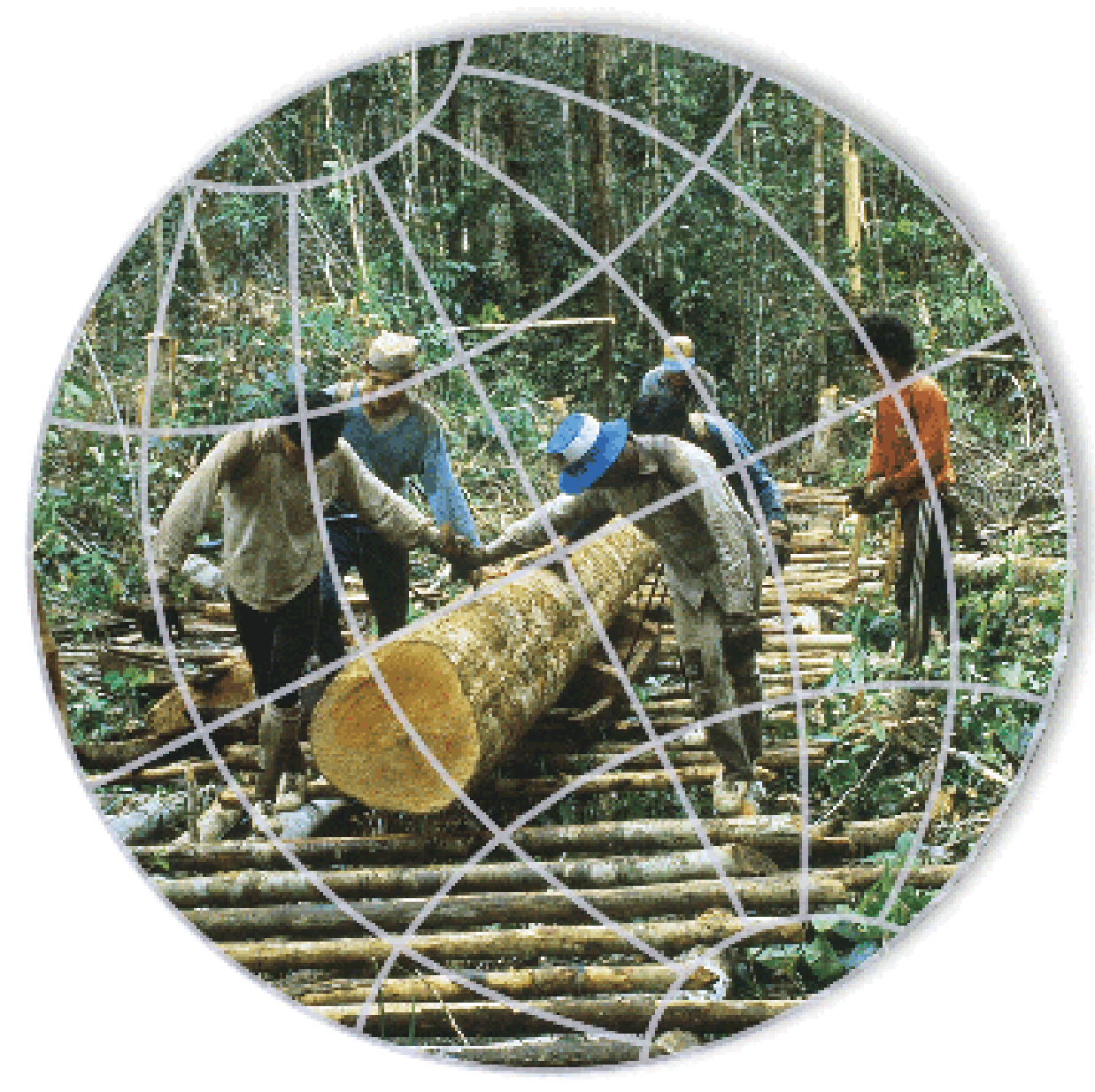




\section{Regional Strategy for Implementing the Code of Practice for Forest Harvesting in Asia-Pacific}

July 2000

ASIA-PACIFIC FORESTRY COMMISSION 
- Cover photo by John Turnbull

\section{Published by}

Center for International Forestry Research (CIFOR)

Mailing address: P.O. Box 6596 JKPWB, Jakarta 10065, Indonesia

Tel.: +62 (251) 622622; Fax: +62 (251) 622100

E-mail: cifor@cgiar.org

Website: http://www.cifor.cgiar.org 


\section{Table of Contents}

Foreword

Acknowledgements

Abbreviations and Definitions vii

Summary 1

1. Introduction 2

1.1 Development of a Regional Code of Practice for Forest Harvesting in Asia-Pacific

1.2 Preparation of the Regional Strategy for Implementing the Code of Practice for Forest Harvesting in Asia-Pacific

2. Need for a Regional Strategy for Implementing the Code of Practice for Forest Harvesting in Asia-Pacific

2.1 Background

2.2 Harvesting Practices

2.3 Need for a Regional Strategy 5

2.4 Asia-Pacific Sub-Regions 6

3. Current Status of Production Forest Management in Asia-Pacific 8

4. Regional Strategy Implementation 10

4.1 Goals and Objectives 10

4.2 Institutional Framework 11

4.2.1 National Codes of Practice 12

4.2.2 Awareness and Training 12

4.2.3 Implementation Guidelines for Codes of Practice 13

4.3 Opportunities 14

4.4 Strategic Plan 14

5. Responsibilities and Timing 26

6. Strategy Outcomes 30

Appendix 1. Asia-Pacific Forestry Commission member countries 31 


\section{Figures}

Figure 1.1. Asia-Pacific Forestry Commission Member Countries 2

Figure 2.1. Global Forest Area by Region 4

Figure 2.2. Production of Tropical Hardwood Logs from South-East Asia and Africa, selected years 1965 to 2010

Figure 2.3. The Asia-Pacific Sub-Regions 6

Figure 2.4. Nominal Groupings of the APFC Member Countries for the Purposes of the Regional Strategy $\quad 7$

Figure 4.1. Organisational Levels and Key Training Target Groups 11

\section{Tables}

Table 3.1. Implementation of Key Elements of Sustainable Forest Management in Asia-Pacific: Country Status

Table 5.1. Responsibilities and Timing for the Implementation of the Regional Strategy 


\section{Foreword}

This Regional Strategy for Implementing the Code of Practice for Forest Harvesting in Asia-Pacific (Regional Strategy) has been developed for use by the Asia-Pacific Forestry Commission (APFC) as a basis for the implementation of the Code of Practice for Forest Harvesting in Asia-Pacific (Code). The Regional Strategy provides details on how to improve forest-harvesting practices, with reduced environmental and social impacts for the Asia-Pacific region.

The Regional Strategy provides continued expression of APFC's commitment to sustainable forest management (SFM). The Regional Strategy is also intended to assist all APFC countries by providing a model for implementing codes of practice that they can adopt, with appropriate modifications to reflect national circumstances.

Most countries of the Asia-Pacific region, through their forestry and/or environmental legislation and policies, have provided strong support for sustainable forest management. The ability of the countries in Asia-Pacific to implement sustainable forest management will be enhanced by implementation of this Regional Strategy. The contents of the Regional Strategy comprise aspects of awareness raising, education and training, development of national codes of practice, and complementary measures for assessing adherence to the Code when applied in the region's forests. 


\section{Acknowledgements}

A number of the member countries of the Asia-Pacific Forestry Commission (APFC) provided staff and financial inputs to ensure the development of this Regional Strategy for Implementing the Code of Practice for Forest Harvesting in Asia-Pacific. Special acknowledgement is made of contributions by the Ministry of Forestry and Estate Crops in Indonesia that served as Task Manager of the APFC ad hoc Working Group on Sustainable Forest Management and hosted the workshop that assisted in the development of this Regional Strategy.

The contributions of the following organisations are also gratefully acknowledged:

- The Australian Government which:

- through the Department of the Environment and Heritage and the Department of Agriculture, Fisheries and Forestry - Australia, provided funding for drafting the Regional Strategy;

- through AusAID, provided funds for the Department of the Environment and the Department of Agriculture, Fisheries and Forestry - Australia to sponsor the pilot Train the Trainer workshop in May 1999. Representing these departments were Brian O'Neill and John Martinez who undertook the role of contract administration and project coordination.

- Grahame Applegate and Dan Raymond from Jaakko Pöyry Consulting (Asia-Pacific) for consulting services.

- Center for International Forestry Research (CIFOR) for technical, logistical support and for publishing the Regional Implementation Strategy.

- Food and Agriculture Organization (FAO) for logistical support and financial assistance to workshop participants and the Secretariat.

- Government of Japan, through the Japan International Forestry Promotion and Cooperation Center (JIFPRO), for funding the September 1998 workshop and the Task Manager's Secretariat.

- US Forest Service for financial assistance

Many other organisations and individuals contributed to this document and their contribution is greatly appreciated. 


\section{Abbreviations and Definitions}

APFC

AusAID

CIFOR

Code

code

COLP

FAO

forest

(FAO definition)

ha

ITTO

JIFPRO

$\mathrm{m}^{3}$

$\mathrm{m}^{3} / \mathrm{a}$

NGO

PFE

PNG

RIL

SFM
Asia-Pacific Forestry Commission

Australian Agency for International Development

Center for International Forestry Research

Code of Practice for Forest Harvesting in Asia-Pacific

Generic term for any code of practice other than the Code of Practice for Forest Harvesting in Asia-Pacific

Code of Logging Practice

Food and Agriculture Organization

Land with tree crown cover (stand density) of more than about $20 \%$ of the area.

Continuous forest with trees usually growing to more than about $7 \mathrm{~m}$ in height and able to produce wood.

hectare

International Tropical Timber Organization

Japan International Forestry Promotion and Cooperation Center

cubic metres

cubic metres per annum

Non-Governmental Organisation

Permanent Forest Estate

Papua New Guinea

Reduced Impact Logging Guidelines

Sustainable Forest Management 


\section{Regional Strategy for Implementing the Code of Practice for Forest Harvesting in Asia-Pacific}

\section{Summary}

This document provides suggestions for an overall strategic framework to achieve implementation of the Code of Practice for Forest Harvesting in Asia-Pacific. Once implemented the Code will optimise the benefits offered by the region's natural production forests and contribute to their sustainable management for the continuing benefit of the community as a whole.

The goals and objectives of this Regional Strategy are expressed as eight strategies for implementation.

1. Encourage appropriate public and political support for implementation of the Code.

2. Develop awareness and support for the Code at the regional and national policymaking levels by stakeholders.

3. Development of a forest sector that is educated and trained in Code implementation.

4. Encourage the development and implementation of national codes based on the Asia-Pacific Code.

5. Establishment of demonstration and training forests.

6. Implementation of monitoring and auditing systems.

7. Collation of past and present research results allowing development of appropriate research activities and directions in support of sustainable forest management.

8. Further development and implementation of sustainable forest management practices in Asia-Pacific.

A time frame for implementation of the Regional Implementation Strategy has also been detailed. This includes target groups who may be able to take responsibility for components of the implementation program over the projected 10-year time horizon. 


\section{Introduction}

The Asia-Pacific Forestry Commission (APFC) comprises 29 countries from the Asia-Pacific region. Appendix 1 provides a list of those countries. Figure 1.1 shows a location map of the member countries.

Figure 1.1 Asia-Pacific Forestry Commission Member Countries

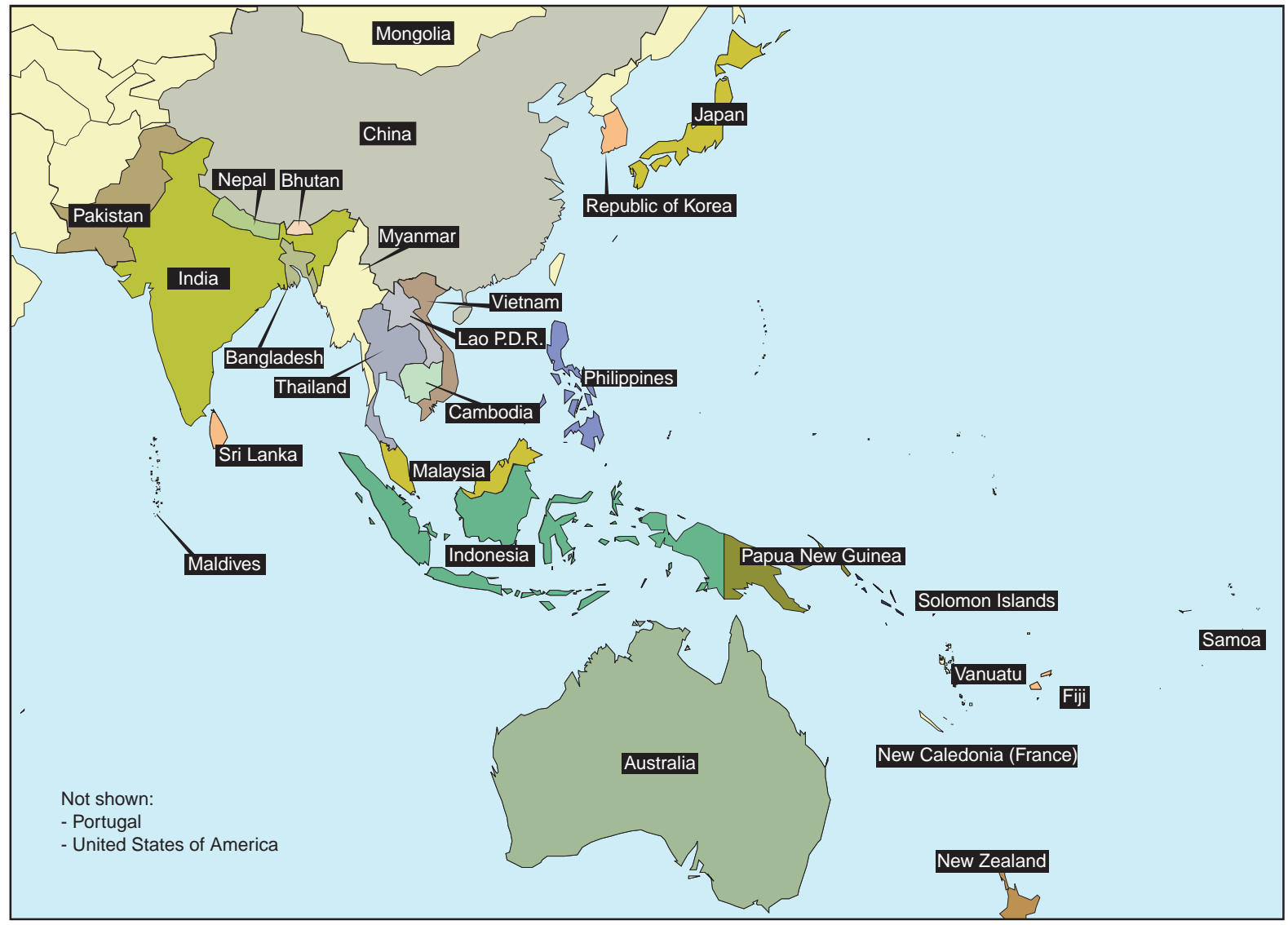

\subsection{Development of a Regional Code of Practice for Forest Harvesting in Asia-Pacific}

The preparation of the Code of Practice for Forest Harvesting in Asia-Pacific (Code) commenced in March 1997 with the first meeting of the APFC ad hoc Working Group on Sustainable Forest Management in Bogor, Indonesia. Participants from APFC member countries agreed on a framework for the Code, including its purpose, scope, coverage and implementation approaches. Development of the AsiaPacific Code began with an extensive review of existing codes throughout Asia-Pacific and other regions around the world. Country visits were then made to Myanmar, Bangladesh and Indonesia where inputs for the Code were obtained. A draft Code was prepared and provided to APFC members prior to a second meeting of the APFC ad hoc Working Group on Sustainable Forest Management in November 1997. The second meeting was attended by 50 representatives from 20 APFC member countries, international organisations, non-governmental organisations (NGOs) and forest industry organisations. The delegates at the meeting reviewed the draft in light of their own national consultations and provided 
further written comments to enable the Code to be tabled for approval at the Seventeenth Session of the APFC held in Indonesia in February 1998.

\subsection{Preparation of the Regional Strategy for Implementing the Code of Practice for Forest Harvesting in Asia-Pacific}

During the Seventeenth Session of the Asia-Pacific Forest Commission, delegates extended and expanded the mandate of the APFC ad hoc Working Group on Sustainable Forest Management to include preparation of a strategy to implement the Code of Practice for Forest Harvesting in Asia-Pacific.

A three-day planning workshop for the APFC ad hoc Working Group on Sustainable Forest Management was convened in September 1998 in Bogor, Indonesia. Participants representing a number of APFC member countries, donors and support organisations attended this meeting. The Working Group provided inputs for the Regional Strategy for Implementing the Code of Practice for Forest Harvesting in AsiaPacific. These inputs were used by Jaakko Pöyry Consulting (Asia-Pacific) for developing a draft of the Regional Strategy under a contract to the Government of Australia (Department of Environment and Department of Agriculture, Fisheries and Forestry - Australia).

The Regional Strategy is designed to outline short and long-term approaches for implementing the Code of Practice for Forest Harvesting in Asia-Pacific with elaboration of sub-regional/country groupings. This draft was distributed to the ad hoc Working Group focal points of the member countries in late 1999 with finalisation of the document after comments in early 2000. 


\section{Need for a Regional Strategy for Implementing the Code of Practice for Forest Harvesting in Asia-Pacific}

\subsection{Background}

The forest area of Asia-Pacific comprises 16\% of the total world forest area of 3.4 billion hectares (Figure 2.1). Asia comprises about $13 \%$ of the world total and Oceania (Pacific) has 3\% of global forest area (Jaakko Pöyry 1997 and FAO 1999).

Figure 2.1 Global Forest Area by Region

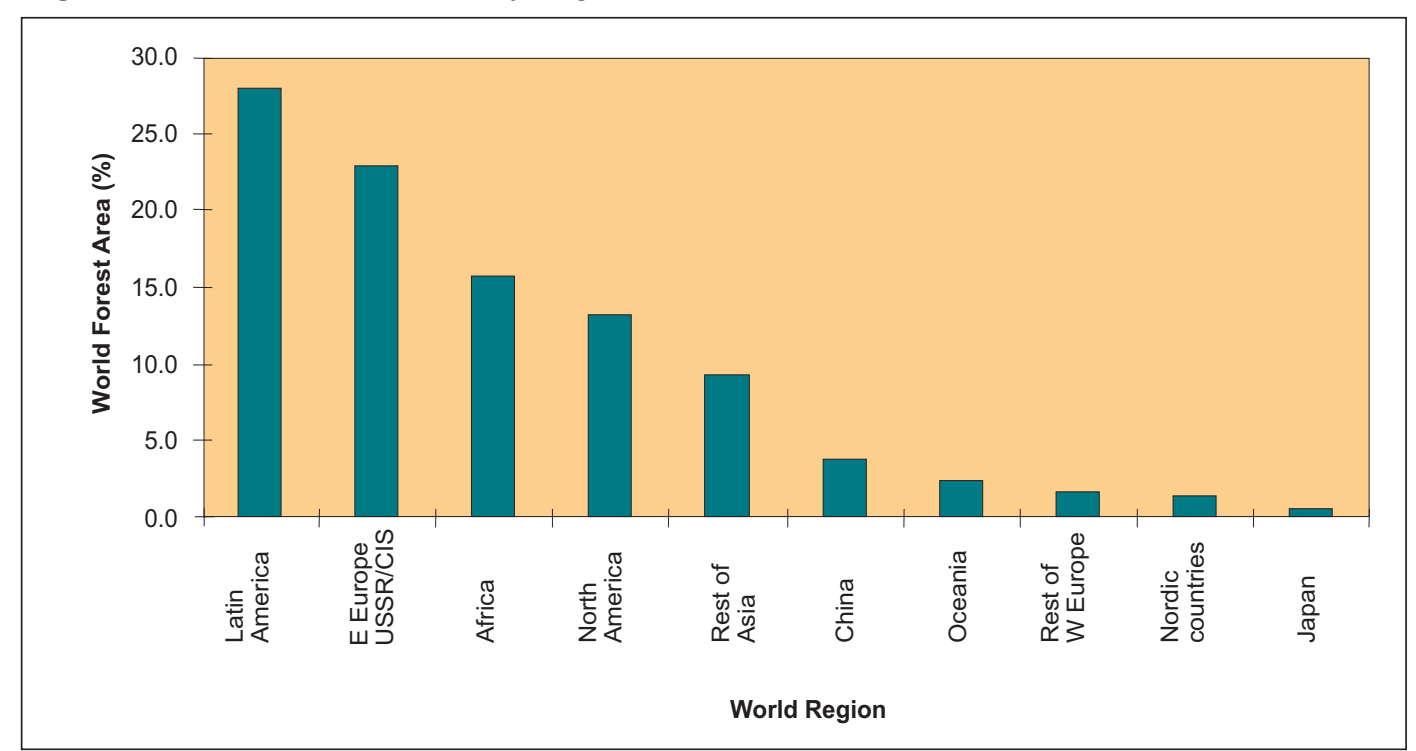

Sources: Jaakko Pöyry 1997 and FAO 1999

Log production continued to grow in Asia-Pacific throughout the 1980s at an annual rate of about 1 million $\mathrm{m}^{3} / \mathrm{a}$ until it peaked in 1989 at 160 million $\mathrm{m}^{3} / \mathrm{a}$. About half of this production was from the tropical hardwood forests of South-East Asia.

The main supply of tropical hardwoods from the Asia-Pacific Region comes from the mixed tropical rainforests in South-East Asia, dominated by the family Dipterocarpaceae. These dipterocarp forests extend in a broad arc from southern Thailand through Sumatra, Peninsular Malaysia, Borneo (Kalimantan, Sarawak, and Sabah) to the Philippines. Seven species of the family occur in Papua New Guinea.

The sawnwood and plywood industries in Japan, Indonesia and Malaysia are major users of tropical hardwood logs and therefore currently rely on these forests. However, with the declining resource, other non-dipterocarp hardwood species are being substituted for plywood production. These include Pometia spp., Calophyllum spp. and Dillenia spp. from Pacific Island countries. There is also an increasing trend toward substitution of tropical hardwoods with softwood timber from plantations of Australia/New Zealand and from the native boreal forests of Russia.

The main areas supplying natural tropical forest logs in Asia-Pacific over the next 15 years will be Kalimantan and Papua in Indonesia and Sarawak in Malaysia; and to a much lesser degree, Papua New Guinea with minor amounts from the Solomon Islands. At the same time, the extensive areas of both hardwood and softwood plantation being established in countries across Asia-Pacific will increase 
production and begin to fill the predicted wood deficit in the region. Large areas of plantation grown expressly to produce sawlogs are already coming on stream in New Zealand and Australia (approximately 3.7 million hectares).

Figure 2.2 provides a comparison of the production of tropical hardwood logs from the major producing countries of South-East Asia and Africa. The tropical countries of Africa are included as much of the volume goes into processing plants in Asia and then on to Japan.

Figure 2.2 Production of Tropical Hardwood Logs from South-East Asia and Africa, selected years 1965 to 2010

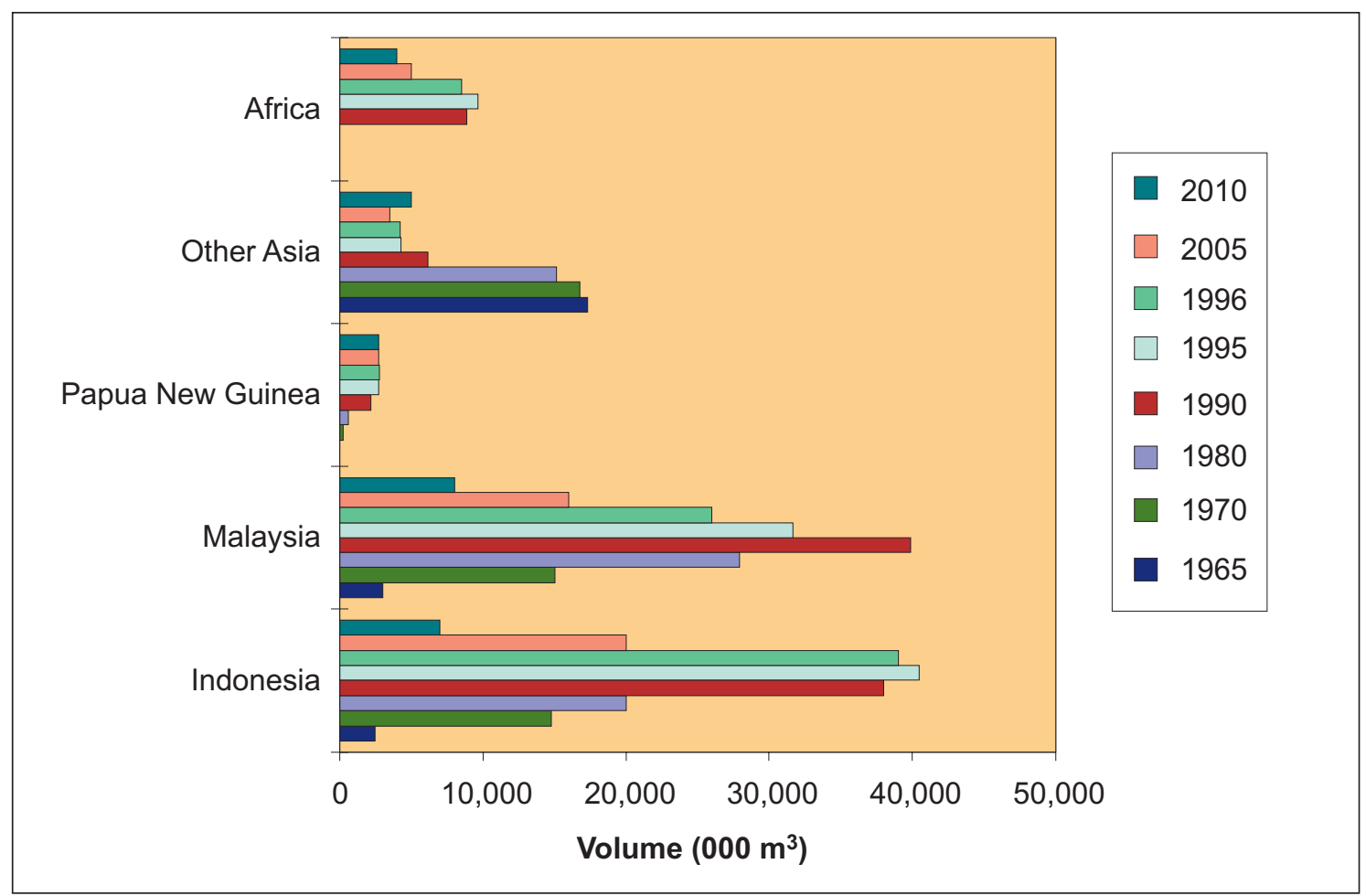

Source: FAO 1997

\subsection{Harvesting Practices}

Most natural forest harvesting operations in Asia-Pacific are carried out using conventional groundbased harvesting techniques. Generally this involves a chainsaw operator carrying out felling and then cross cutting either in the forest or on the landing. A crawler tractor or skidder then extracts trees or logs to a landing for measurement and loading before being carted to the log buyer. While there are variations, such as mechanised falling, animal extraction, hand extraction/loading etc, most operations are of this form. The Code of Practice for Forest Harvesting in Asia-Pacific is therefore targeted at this form of operation, although the principles and practices detailed apply generally to all harvesting operations.

\subsection{Need for a Regional Strategy}

The large volumes of timber being harvested from Asia-Pacific are a significant component of the economies of many countries in the region. These countries rely heavily on this resource and are 
dependent on the ecological and social sustainability of their forests in the long term. Like many tropical forests throughout the world, the region's forests have the potential to provide raw material and other tangible and non-tangible benefits in perpetuity, providing certain changes are made to harvesting practices. A major step in the process of providing for these changes was the preparation of the Code of Practice for Forest Harvesting in Asia-Pacific. The next fundamental component of the process is to prepare a Regional Strategy for implementing the Code for the sustainable management of the remaining production forests.

\subsection{Asia-Pacific Sub-Regions}

The Asia-Pacific region can be divided into sub-regions based on geographic location. This incorporates similarities in forest types, ethnic groups and land tenure systems. The separation into sub-regions also facilitates the development of a Regional Strategy for the implementation of the Code. This subregionalisation allows the grouping of countries with similar forest types and land tenure systems with advantages for developing lower-cost training and awareness programs. Figure 2.3 shows a nominal breakdown of the Asia-Pacific region into four sub-regions: South Asia, South-East Asia, East Asia and the Pacific.

Figure 2.3 The Asia-Pacific Sub-Regions

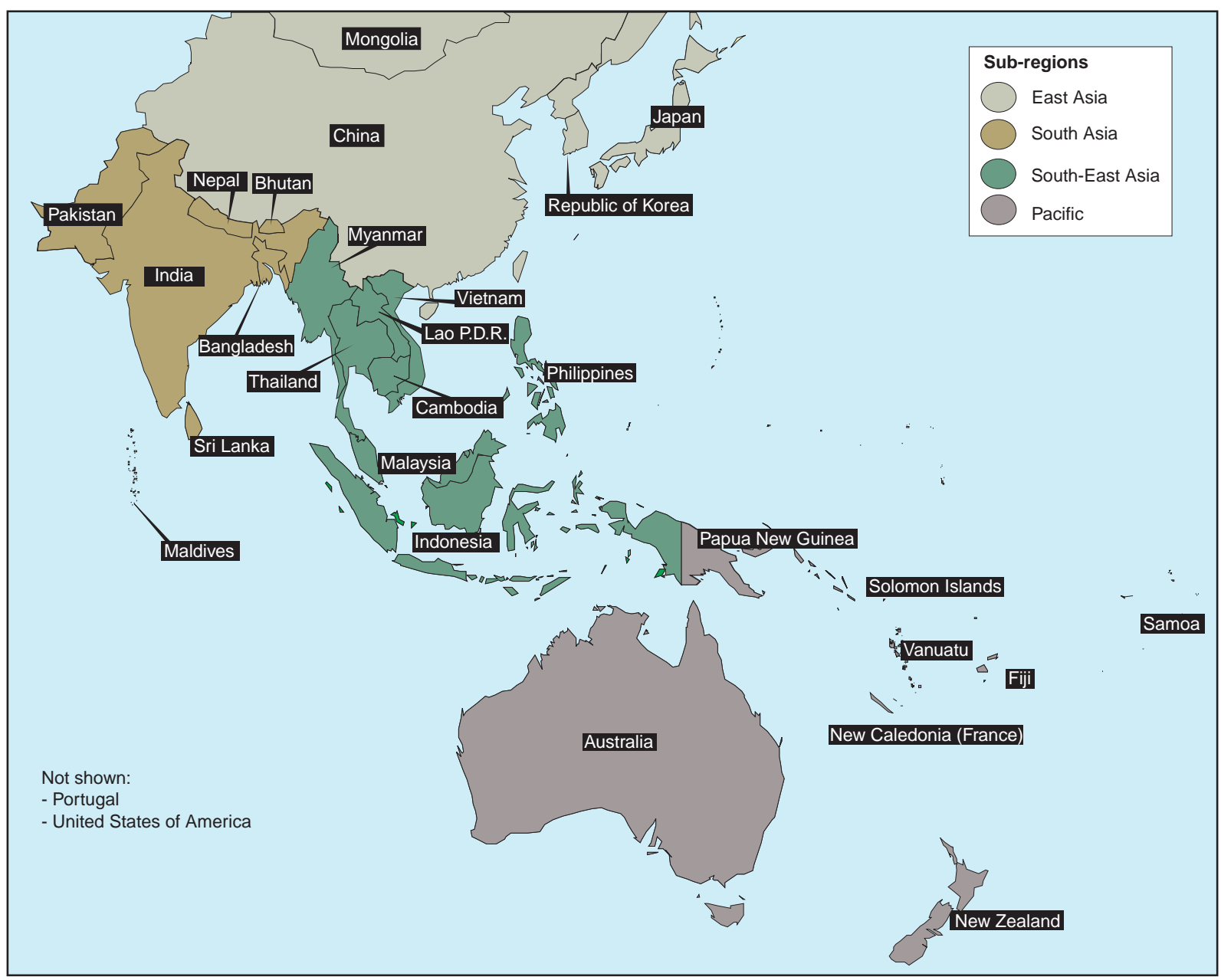


Figure 2.4 includes the nominal groupings of the Asia-Pacific member countries and indicates some of the policy inputs to Code development. It also highlights that the Pacific countries have already developed a 'Code of Conduct for Logging Indigenous Forests in Selected South Pacific Countries'. This document is similar to the Code of Practice for Forest Harvesting in Asia-Pacific, and has provided the template for Pacific countries to develop their own national codes. While Australia and New Zealand are listed in this grouping, the Pacific code was originally designed for tropical hardwood forest and therefore is not fully applicable to either of these countries, or other APFC member countries with non-tropical forests. Both countries have developed and implemented their own codes of practice that are relevant to their forest types and silvicultural regimes.

Figure 2.4 Nominal Groupings of the APFC Member Countries for the Purposes of the Regional Strategy

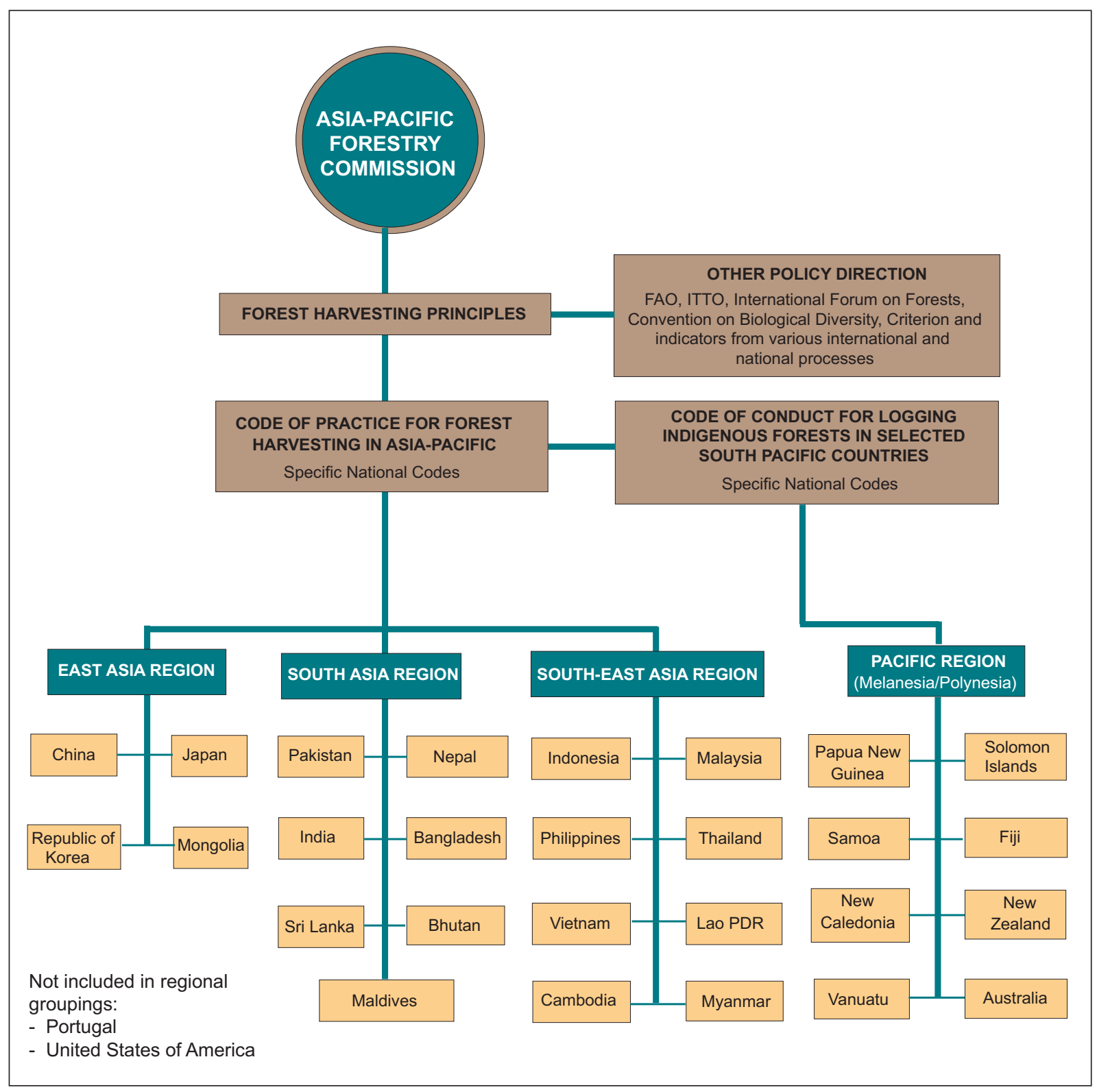




\section{Current Status of Production Forest Management in Asia-Pacific}

APFC countries independently develop and implement a range of forest management practices (Table 3.1). In many cases, countries have a series of guidelines or systems that act in the same way as Codes of Practice, Reduced Impact Harvesting Guidelines etc, or are in the process of developing these management systems. Table 3.1 also provides information on the status of specific elements of sustainable forest management of APFC countries. A demonstration forest refers to a model forest developed specifically for research into improved practices, training and demonstration purposes according to a country's best management practices.

The status of Silvicultural Prescriptions have not been included in Table 3.1. A number of countries in the region have been reviewing their current silvicultural practices and the effect that implementation of these prescriptions have had on the residual stands and actual growth rates. It is recognised that many of the silvicultural prescriptions refer to legislated diameter cutting limits for all species in broad forest types. They are seldom prescriptions developed from research activities designed to assess the biological capacity of the different forests or on an understanding of the ecology of the species to be harvested, or of those to remain in the residual stand. A number of countries in the Pacific, have recognised the need to review their silvicultural practices and have made progress towards revision.

The intended focus of this Regional Strategy is on countries within Asia-Pacific. For this reason Portugal, France, the United Kingdom and the United States of America are not included in Table 3.1. 


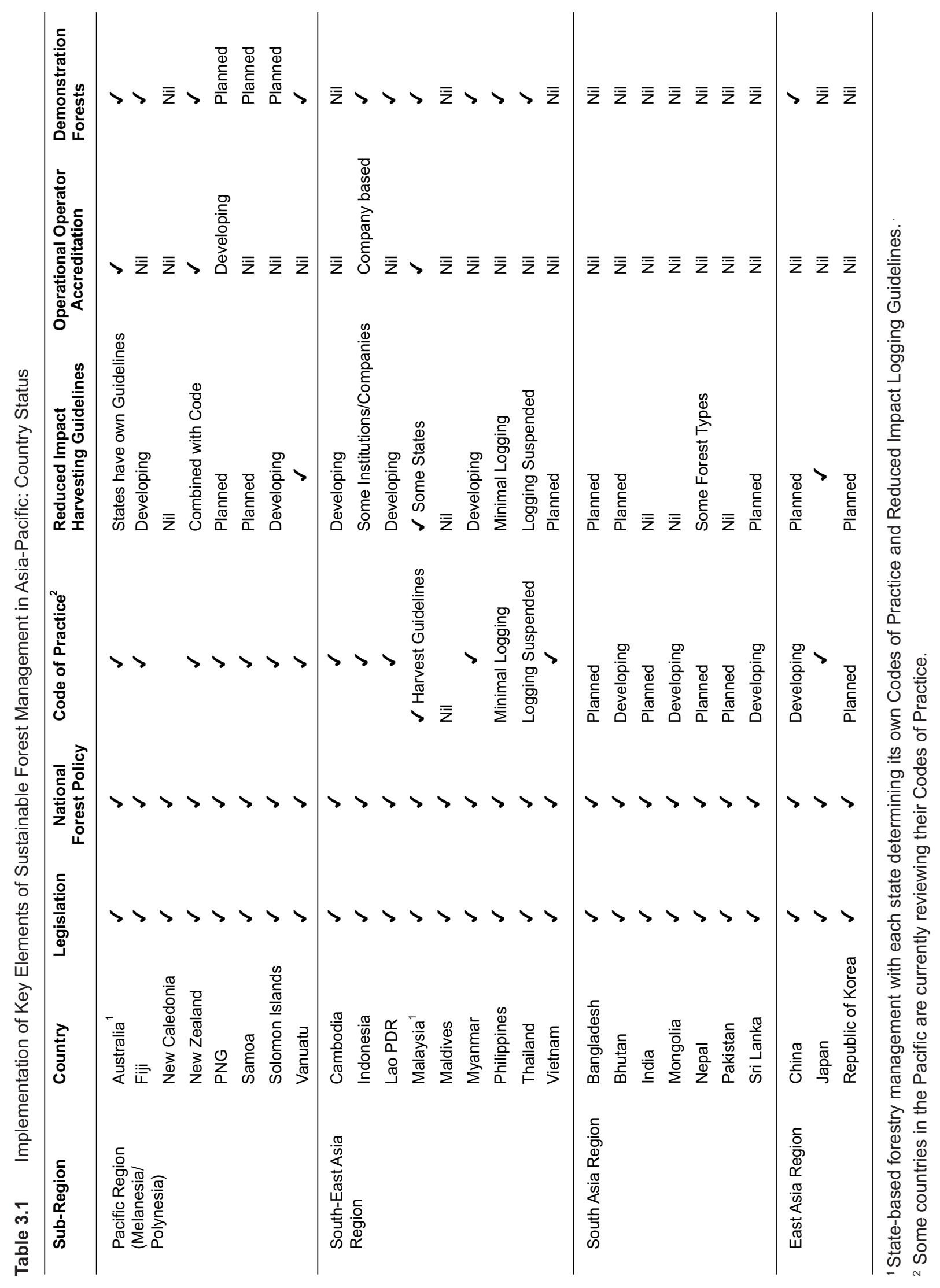




\section{Regional Strategy Implementation}

The purpose of this Regional Strategy is to achieve implementation of the Code of Practice for Forest Harvesting in Asia-Pacific. Implementation of this Code will enhance the management of native forests throughout the Region by increasing efficiency of harvesting operations while providing more environmentally sensitive management practices.

Stakeholders in this Regional Strategy include industry, forest departments, NGO bodies and community groups. All will have to work together with a common goal to achieve the changes required at the institutional, policy and operational levels to effectively implement the Code.

This Regional Strategy outlines the actions required by the stakeholders to achieve effective implementation of the Code. The actions detailed include initiatives to improve management of all production forests through improved management systems and institutional development to improve capacity and capability of staff of both the public and private sector organisations. Indirect actions are also included in the strategy, whereby government can create a policy environment in which private sector decisions can benefit the community as a whole.

\subsection{Goals and Objectives}

The overall goal of the Regional Strategy for the Development and Implementation of the Code of Practice for Forest Harvesting in Asia-Pacific is to optimise the benefits offered by the region's natural production forests and to contribute to the sustainable development and management of these forests for the continuing benefit of the communities in the region.

This goal can best be achieved by defined outcomes that meet the following eight strategic objectives:

1. Encouraging appropriate public and political support for implementation of the Code.

2. Developing awareness and support for the Code at the regional and national policy-making levels by stakeholders.

3. Development of a forest sector that is educated and trained in Code implementation.

4. Encouraging the development and implementation of national codes based on the AsiaPacific Code.

5. Establishment of demonstration and training forests.

6. Implementation of monitoring and auditing systems.

7. Collation of past and present research results allowing development of appropriate research activities and directions in support of sustainable forest management.

8. Further development and implementation of sustainable forest management practices in Asia-Pacific. 


\subsection{Institutional Framework}

To foster institutional change, both regionally and nationally within APFC member countries; staff capacity at all levels within and outside government must be addressed in a manner which provides for their needs and empowers them to manage the process of change. Within any institution, staff can generally be divided into four levels (Figure 4.1). The triangle in Figure 4.1 represents one of many organisations, while the box above represents the regional and national policy makers who set the policy directions.

Figure 4.1 Organisational Levels and Key Training Target Groups

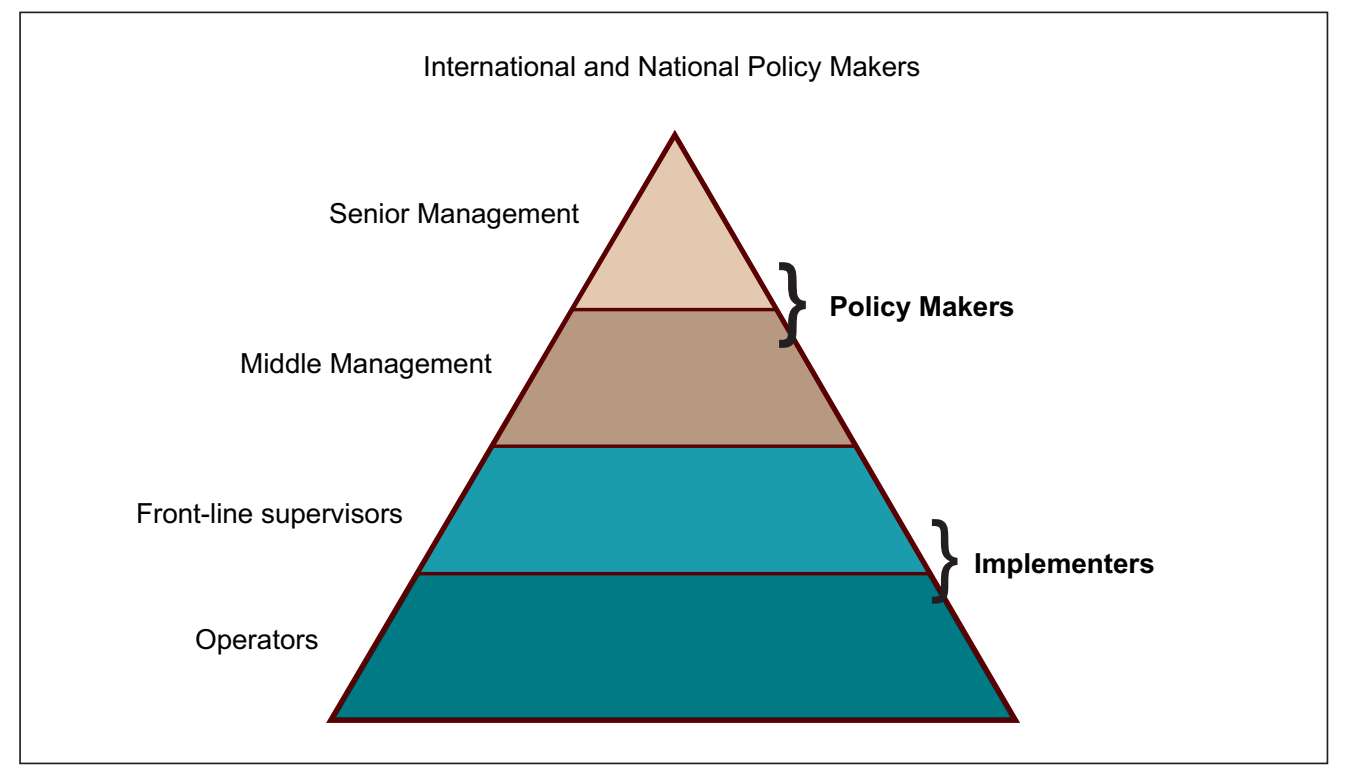

Depending on an organisation's management structure, the triangle shown in Figure 4.1 can be a flat structure with a small number of managers and a large number of operating staff, e.g. typical logging company; or with a more hierarchical structure, e.g. forestry departments. As a general rule, change is instituted at the policy level by senior and middle level management. Middle-level management then has the task of refining policy into implementable structures and actions that can be adopted by staff at the ground level. It is only when staff at all levels of an institution adopt a practice that it truly becomes 'institutionalised'.

To commence this process of institutional change, a number of key change agents and actions are required. Change agents are generally people who are in key positions within an organisation where they have the opportunity to drive change. They must have the ability to transfer information, motivate others and convert policy to a practical level whereby it can be applied.

Initially the drive for change must come from the APFC and other similar bodies through the mechanisms that are outlined in this strategy. It will then be the responsibility of individual countries to take the directions set by the APFC and apply them, first at the policy level and then at the operational level. 


\subsubsection{National Codes of Practice}

The Code of Practice for Forest Harvesting in Asia-Pacific has provided a broad framework for the development of national codes of harvesting practice and/or sets of operational guidelines. It is now the responsibility of individual APFC member countries to take this framework and use it to develop their own national codes and/or sets of guidelines. These codes should be country specific and in some cases may need to be forest type specific. Forest type specific codes may be applicable across a number of countries. For example, mangrove forests occur in many APFC countries (Bangladesh, Malaysia, India, Vietnam) and while the requirements for management of mangrove forests are quite specific to this forest type they also remain relatively similar from country to country. Swamp forest logging and harvesting of high elevation forests are also likely to require forest specific codes.

A number of the APFC countries already have national codes of practice or similar guidelines, particularly among the Pacific member countries. Many of these countries are now reaching a point were their codes/guidelines require revision. The Code of Practice for Forest Harvesting in Asia-Pacific provides a basis on which these countries may decide to further refine their codes.

While this document provides a strategy for implementation of the Code of Practice for Forest Harvesting in Asia-Pacific, it will be necessary for individual countries to develop their own national plans for implementation. It is envisaged that these would be complementary to the broad guidelines of this Regional Strategy in content and timing.

\subsubsection{Awareness and Training}

It is recommended that the initial key element for the implementation of the Code of Practice for Forest Harvesting in Asia-Pacific be a major awareness and training program. This will serve two purposes:

- Help spread the message at all levels within stakeholder groups that the Code of Practice for Forest Harvesting in Asia-Pacific exists and is to be adopted nationally in order to further improve practices.

- Assist with the training of a group of key change agents, providing them with the Train the Trainer skills to train others throughout the APFC region and within their respective countries.

The training program will need to have two target groups:

1. Trainers - The group of specialist training staff who require trainer training skills.

2. Implementers - The main body of an organisation who take the information provided by the trainers and apply it at all levels throughout their respective organisation. Implementers can come from all levels but the focus is on middle-level management and the operators.

A side benefit of the training program is that it will also assist to rapidly spread awareness of the Code.

\section{Training of Trainers}

At the commencement of any institutionalisation program, training of trainers is essential. This is the program that develops the key change agents who then become the catalyst for change at all levels in an organisation. In this case, a Train the Trainer program would have two requirements. Firstly, it would provide the target group of trainers with the skills to teach others effectively. There is considerable difference between talking to a group and effective training. Training should utilise 
adult learning principles, be target group specific and systematically plan and deliver the message in the most interactive way possible. After completion of the initial Train the Trainers program, the group of key change agents should have sufficient teaching skills to allow them to develop their own country-specific training curriculum.

The second element of the Train the Trainers program is to provide participants with a full understanding of what a code of practice is, what it does and how it should be applied operationally so they can communicate this information to others. A pilot regional Train the Trainers program was undertaken in Malaysia during May 1999 with funds provided to the Department of Environment and Heritage and the Department of Agriculture, Forestry and Fisheries - Australia by AusAID. This learning experience has served as the basis for future training programs. A curriculum has now been developed to provide guidance for future workshops of this nature.

\section{Training of Implementers}

Training of implementers could commence once training of trainers is completed. This would generally involve trainers using systematic training techniques to teach three target groups, i.e. policy, middle level and implementers (operators and supervisors). They must make participants aware of the codes (both national, and where applicable, the Asia-Pacific Code), teach the benefits of applying the contents of these documents and make the target groups familiar with the application of the practices at their respective levels. The trainees would then most likely need some practical follow-up support to assist them in converting the training to operational practices.

Operator training needs to be far more practical and specific to the needs of the operator's job task. Awareness of the Code must be included along with the skills to allow compliance, e.g. directional falling. At the upper level of operator training, competency-based programs can be provided and set as a required standard for operators to work in the forest.

At the completion of these programs, follow-up training, intensive monitoring and, where required, penalties for non-compliance should ensure that the Code of Practice for Forest Harvesting in AsiaPacific and/or a national code is implemented according to the timetable developed by individual countries.

\subsubsection{Implementation Guidelines for Codes of Practice}

While the purpose of this strategy is to detail a series of actions to assist APFC countries to implement the Code regionally and develop and fully implement national codes of practice for timber harvesting, this is only one of a number of elements required to improve the standard of forest harvesting in the region. A code sets a series of minimum standards for 'what to do' in a harvesting operation. Experience in the Pacific has shown that two other essential elements are required to truly lift the standard of harvesting practices and ensure that post-harvesting stands remain viable into the future. These are improved silvicultural prescriptions and reduced impact logging guidelines (RIL).

Silvicultural prescriptions should be developed based on a single forest type and the desired postharvest stand structure that must be maintained to enable the forest to remain viable following harvesting. A silvicultural prescription gives the 'why' component of forest management. It should prescribe requirements for potential crop trees, species-specific diameter cutting limits, seed trees, allowable removals per hectare, maximum and minimum percentages of canopy disturbance and post-harvesting activities such as stand improvement. 
RIL guidelines are commonly referred to as the 'how' of forest harvesting. These guidelines are based on the Code and provide the knowledge of how the Code will be implemented. They must be quite specific and measurable, ensuring field application can be monitored for improvements and audited for compliance.

In the future it would be prudent for the APFC to consider providing support for the development of regional sets of Reduced Impact Logging guidelines and a framework for forest type based, sub-regional silvicultural prescriptions ${ }^{1}$. This could be done through a similar process to that used to develop the Code.

\subsection{Opportunities}

The publication of the Code of Practice for Forest Harvesting in Asia-Pacific provides an ideal opportunity for the region to move forward, raising the standard of forest management practices throughout the region. A pilot regional Train the Trainer Workshop on Implementation of the Code of Practice for Forest Harvesting in Asia-Pacific has been completed in Malaysia. Along with a Study Tour to Malaysia, this has commenced the implementation program for the region and provides the first group of change catalysts. With further support, both on national and regional bases, this group will be able to commence the process of institutionalising fundamental changes in forest harvesting practices across the region.

\subsection{Strategic Plan}

Strategies comprise sets of actions that are required to achieve the overall goal. These actions are designed to maximise identified opportunities and to minimise constraints. The eight strategies required to move towards and achieve the main goal have been prepared, together with an indication of the actions required and the expected outcomes.

It should be noted that the strategies are not single entities in themselves, but overlap and are reliant on each other. For example, without political will to move the process forward (Strategy 1), there will be little hope of progressing the other strategies. However, the political will is unlikely to develop without awareness at the regional and national levels (Strategies 2 and 3). It is therefore important that the actions under each strategy are examined as a whole and occur simultaneously if the desired outcomes are to be achieved.

The process of developing a national code is described in the strategies. It should be noted that some countries are likely to take this further to a state, region or province level. For example, each of the six states of Australia has its own code.

These strategies focus on outcomes and are intended to set directions for policy formulation and donor support for funding to achieve region-wide implementation of the Code of Practice for Forest Harvesting in Asia-Pacific. 


\section{Strategy 1}

\section{Encourage Appropriate Public and Political Support for Implementation of the Code}

Ensuring the appropriate policy and legal framework is in place is fundamental to providing the necessary incentives to encourage the contents of the Code to be implemented. For concession owners or those with the rights to manage or utilise a forest, policies need to address the exclusivity or security of the harvesting rights, the transferability of those rights, the divisibility which allows transfers to take place, enforceability and the presence of a free market for the sale of the forest products.

\begin{tabular}{|c|c|c|}
\hline Objectives & Actions & Outcomes \\
\hline $\begin{array}{l}\text { To develop appropriate } \\
\text { legal frameworks and } \\
\text { incentive awareness } \\
\text { based systems to } \\
\text { achieve Code } \\
\text { implementation. }\end{array}$ & $\begin{array}{l}\text { The Forestry Department in conjunction } \\
\text { with other stakeholders to review and } \\
\text { determine potential policy and legislative } \\
\text { changes to achieve Code implementation. } \\
\text { The Forestry Department to analyse } \\
\text { current mechanisms for encouraging } \\
\text { compliance and where required } \\
\text { enforcement of legislation and guidelines } \\
\text { on forestry practice. } \\
\text { - Forestry Department in conjunction with } \\
\text { relevant government departments to } \\
\text { determine the best combination of } \\
\text { incentive, awareness and enforcement } \\
\text { mechanisms to achieve enactment and } \\
\text { enforcement of the Code, e.g. through } \\
\text { legislative requirements, conditions } \\
\text { binding on harvesting licences etc. This } \\
\text { may require drafting of legislation or } \\
\text { development and approval of incentives/ } \\
\text { sanctions for voluntary implementation. } \\
\text { Forestry Department to obtain political } \\
\text { support to implement the best combination } \\
\text { of incentive and legislative based } \\
\text { enforcement mechanisms through the } \\
\text { proposal of legislative and policy changes. }\end{array}$ & $\begin{array}{l}\text { Understanding of the success or } \\
\text { failure of current forest } \\
\text { management guidelines and the } \\
\text { advantages/disadvantages of using } \\
\text { a range of incentives, awareness } \\
\text { techniques and enforcement } \\
\text { mechanisms for Code } \\
\text { implementation. } \\
\text { Development of a legal framework } \\
\text { or a reward-based voluntary } \\
\text { framework for the implementation } \\
\text { of the Code. }\end{array}$ \\
\hline $\begin{array}{l}\text { To prepare the political } \\
\text { environment for } \\
\text { acceptance of and a } \\
\text { proactive stance on } \\
\text { instituting the Code. }\end{array}$ & $\begin{array}{l}\text { The APFC to release a statement formally } \\
\text { supporting the development of national } \\
\text { codes based on the Asia-Pacific Code. } \\
\text { This is to be signed by and circulated to all } \\
\text { member countries. } \\
\text { Within } 2 \text { years of the APFC meeting, a } \\
\text { follow-up meeting to be held on a sub- } \\
\text { regional basis for the Asia groups to } \\
\text { review progress and determine strategies } \\
\text { for overcoming obstacles to this point in } \\
\text { time. } \\
\text { Pacific countries to continue review of } \\
\text { their Pacific Regional Code with findings } \\
\text { on best practices being used to assist Asia } \\
\text { group countries when they reach the } \\
\text { review stage. }\end{array}$ & $\begin{array}{l}\text { - Increased pressure on all countries to } \\
\text { institute forest practices reform } \\
\text { through the Code. } \\
\text { - An environment of acceptance for the } \\
\text { Code by member countries and } \\
\text { generate a clear target for } \\
\text { implementation, e.g. Code } 2001 \\
\text { similar to ITTO's Target } 2000 . \\
\text { - Growing enthusiasm for } \\
\text { institutionalisation of the Code and } \\
\text { assist countries overcome some of the } \\
\text { obstacles encountered through group } \\
\text { workshopping of difficulties } \\
\text { encountered to this point in time. } \\
\text { Asia group countries have } \\
\text { recommended steps for further } \\
\text { refining their Code development } \\
\text { process based on the experience of } \\
\text { Pacific countries. }\end{array}$ \\
\hline
\end{tabular}




\section{Strategy 2}

\section{Develop Awareness and Support for the Code at the Regional and National Policy- Making Levels by Stakeholders}

A fundamental component of having the Code implemented is to ensure the policy makers are fully aware of the Code, what it is designed to do and how it can be implemented.

\begin{tabular}{|c|c|c|}
\hline Objectives & Actions & Outcomes \\
\hline $\begin{array}{l}\text { To improve awareness } \\
\text { throughout the APFC } \\
\text { member countries at the } \\
\text { policy level of the } \\
\text { existence and broad } \\
\text { content of the Code of } \\
\text { Practice for Forest } \\
\text { Harvesting in Asia-Pacific } \\
\text { and its purpose. }\end{array}$ & 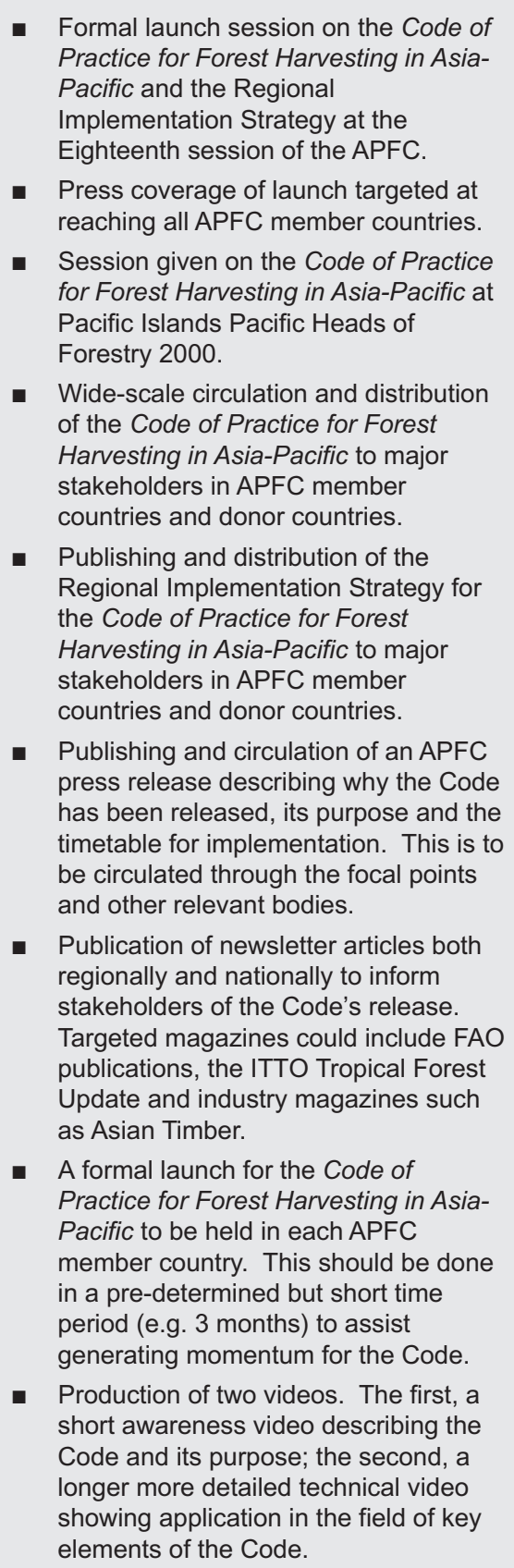 & $\begin{array}{l}\text { Greater awareness of the existence of } \\
\text { the Code of Practice for Forest } \\
\text { Harvesting in Asia-Pacific and the } \\
\text { implementation strategy at the policy } \\
\text { level within the Forestry Department. } \\
\text { - Formal documentation detailing the } \\
\text { APFC's planned implementation } \\
\text { strategy. } \\
\text { Copies of the Code of Practice for } \\
\text { Forest Harvesting in Asia-Pacific and } \\
\text { the Regional Implementation Strategy } \\
\text { sent to most stakeholder groups } \\
\text { spreading awareness and providing } \\
\text { individuals and organisations with the } \\
\text { required information to progress } \\
\text { implementation. } \\
\text { Greater awareness at all levels of the } \\
\text { existence of the Code of Practice for } \\
\text { Forest Harvesting in Asia-Pacific and } \\
\text { the implementation strategy. } \\
\text { A formal launch and acceptance of the } \\
\text { Code of Practice for Forest Harvesting } \\
\text { in Asia-Pacific by each APFC member } \\
\text { country. } \\
\text { Development of awareness and } \\
\text { training aids. }\end{array}$ \\
\hline
\end{tabular}




\begin{tabular}{|c|c|c|}
\hline Objectives & Actions & Outcomes \\
\hline $\begin{array}{l}\text { To provide a dedicated } \\
\text { person tasked to carry out } \\
\text { code awareness, training } \\
\text { and implementation } \\
\text { activities on a regional } \\
\text { basis and in a support role } \\
\text { as requested at the } \\
\text { national level. }\end{array}$ & $\begin{array}{l}\text { APFC to seek funding for a Code } \\
\text { implementation officer for a period of } \\
\text { not less than } 2 \text { years. } \\
\text { Job description for the Code } \\
\text { implementation officer to be developed } \\
\text { by the ad hoc Working Group based on } \\
\text { the requirements of this implementation } \\
\text { strategy and other perceived needs. } \\
\text { - A suitable applicant to be selected. }\end{array}$ & $\begin{array}{l}\text { A specialised and dedicated Code } \\
\text { implementation officer capable of } \\
\text { actively progressing the } \\
\text { implementation strategy across the } \\
\text { region. }\end{array}$ \\
\hline $\begin{array}{l}\text { To encourage adoption of } \\
\text { the code in order to } \\
\text { realise its benefits. }\end{array}$ & $\begin{array}{l}\text { Obtain funding through APFC donor } \\
\text { countries and other sources to provide } \\
\text { a general fund for Code } \\
\text { implementation activities. These funds } \\
\text { should be allocated at the discretion of } \\
\text { the ad hoc Working Group but are } \\
\text { likely to assist the Code } \\
\text { implementation officer to conduct } \\
\text { awareness and training activities and } \\
\text { provide funds that can be channelled to } \\
\text { national steering committees to assist } \\
\text { their implementation activities. } \\
\text { Pursue support from donor countries to } \\
\text { sponsor a minimum of } 1 \text { participant } \\
\text { from the 'policy maker' group of each of } \\
\text { the relevant Forestry Department, } \\
\text { NGO, industry and community bodies } \\
\text { of each APFC country to attend the } \\
\text { Train the Trainer workshop series. As } \\
\text { Forest Departments are likely to have } \\
\text { the lead role, a minimum of } 2 \\
\text { participants is appropriate to cover } \\
\text { contingencies. }\end{array}$ & $\begin{array}{l}\text { A minimum of } 1 \text { key person within } \\
\text { each stakeholder group and } 2 \\
\text { persons from the Forest Department } \\
\text { of each APFC member country } \\
\text { understands the process that is under } \\
\text { way and has the skills to pass the } \\
\text { information on to others. }\end{array}$ \\
\hline $\begin{array}{l}\text { To create an environment } \\
\text { where there will be } \\
\text { stakeholder acceptance } \\
\text { of the Code }\end{array}$ & $\begin{array}{l}\text { Conduct a series of sub-regional Train } \\
\text { the Trainer workshops with key Forest } \\
\text { Department, industry, NGO and } \\
\text { landowner representatives from APFC } \\
\text { member countries. } \\
\text { Provide follow-up support for } \\
\text { participants in the Train the Trainer } \\
\text { program to run in country training } \\
\text { programs. }\end{array}$ & $\begin{array}{l}\text { Availability of a trained core of } \\
\text { individuals capable of preparing and } \\
\text { commencing the process of } \\
\text { implementing the Code of Practice for } \\
\text { Forest Harvesting in Asia-Pacific } \\
\text { within their respective organisations. }\end{array}$ \\
\hline
\end{tabular}




\section{Strategy 3}

\section{Development of a Forest Sector That Is Educated and Trained in Code Implementation}

If the Code is to be implemented, it is imperative that all staff in the forest sector are motivated and have the necessary education and training. Staff from all stakeholder groups require an understanding of the science behind the Code as well as the content and what it means when put into practice. With this knowledge will come the understanding of the reasons for a Code, resulting in a desire and pride in achieving implementation.

\begin{tabular}{|c|c|c|}
\hline Objectives & Actions & Outcomes \\
\hline $\begin{array}{l}\text { To improve the } \\
\text { understanding of forest } \\
\text { sector personnel in } \\
\text { implementation of } \\
\text { sustainable forest } \\
\text { management practices. }\end{array}$ & $\begin{array}{l}\text { Conduct a 'needs analysis' survey to } \\
\text { determine training and awareness } \\
\text { requirements within APFC countries } \\
\text { and priorities for support activities } \\
\text { based on current harvesting, } \\
\text { supervision and legislative systems. } \\
\text { This should be regionally co- } \\
\text { ordinated by FAO and/or the Code } \\
\text { implementation officer through the } \\
\text { focal points of each APFC country to } \\
\text { determine regional priorities. } \\
\text { As a component of awareness and } \\
\text { training programs on the Code of } \\
\text { Practice for Forest Harvesting in } \\
\text { Asia-Pacific include the concept of } \\
\text { sustainable forest management in the } \\
\text { program of all training workshops. } \\
\text { A series of field tours to a suitable } \\
\text { demonstration forest and harvesting } \\
\text { area to be held for selected Forestry } \\
\text { Department, Industry, landowner and } \\
\text { NGO personnel. Initially this will be } \\
\text { on a sub-regional basis but will later } \\
\text { be on a country basis. It is } \\
\text { suggested that the Code } \\
\text { implementation officer be responsible } \\
\text { for organisation of these tours. }\end{array}$ & $\begin{array}{l}\text { - Support, training and awareness } \\
\text { requirements of member countries } \\
\text { identified and prioritised within } \\
\text { member countries. } \\
\text { - Allocation of resources based on } \\
\text { identified priorities to achieve } \\
\text { successful implementation of the } \\
\text { Code. } \\
\text { - Trainees with a better } \\
\text { understanding of the full } \\
\text { requirements for achieving } \\
\text { sustainable forest management. } \\
\text { Participants develop an } \\
\text { understanding of what a good } \\
\text { forest harvesting operation looks } \\
\text { like and aim at producing the } \\
\text { same type of operational standard } \\
\text { in their own countries. }\end{array}$ \\
\hline $\begin{array}{l}\text { To improve the quality } \\
\text { of forest harvesting } \\
\text { operations through } \\
\text { Code implementation. } \\
\text { To create a body of } \\
\text { trained supervisory } \\
\text { and industry staff. }\end{array}$ & $\begin{array}{l}\text { Conduct a series of regional Train the } \\
\text { Trainer workshops with personnel } \\
\text { from key stakeholder groups within } \\
\text { APFC member countries. Workshop } \\
\text { coordination and curriculum should } \\
\text { be the responsibility of the Code } \\
\text { implementation officer based on the } \\
\text { existing pilot workshop. } \\
\text { Staff from the regional Train the } \\
\text { Trainer workshops to conduct in- } \\
\text { country awareness and training } \\
\text { programs based on their own national } \\
\text { codes and where appropriate on the } \\
\text { Code of Practice for Forest } \\
\text { Harvesting in Asia-Pacific. }\end{array}$ & $\begin{array}{l}\text { An increased number of key } \\
\text { personnel who share the vision for } \\
\text { implementation of the Code and } \\
\text { have the required skills to be a part } \\
\text { of implementing that vision. } \\
\text { - Greater awareness of the regional } \\
\text { and national codes and the } \\
\text { requirements for implementation. } \\
\text { - Stakeholders aware of and } \\
\text { beginning to prepare for Code } \\
\text { implementation. } \\
\text { - Funding to support the national } \\
\text { implementation programs. } \\
\text { - A pool of trained staff to conduct } \\
\text { the implementation program. }\end{array}$ \\
\hline
\end{tabular}




\begin{tabular}{|l|l|l|}
\hline Objectives & Actions & Outcomes \\
\hline & $\begin{array}{l}\text { Funds to be pursued on regional and } \\
\text { national bases to run in country } \\
\text { awareness and Train the Trainer } \\
\text { programs. }\end{array}$ & $\begin{array}{l}\text { Village or community-based } \\
\text { operations complying with the Code. } \\
\text { Supervisors and operators with a } \\
\text { clear understanding of the } \\
\text { requirements that they must meet to } \\
\text { achieve conformance with the } \\
\text { national code. }\end{array}$ \\
& $\begin{array}{l}\text { Staff from the regional Train the } \\
\text { Trainer program to run supported, in- } \\
\text { country, Train the Trainer workshops } \\
\text { based on the national code, or where } \\
\text { appropriate the Asia-Pacific Code. } \\
\text { Initially it is envisaged that back-up } \\
\text { support and mentoring be provided by } \\
\text { the lead trainers at the regional Train } \\
\text { the Trainer program. } \\
\text { NGO staff who have attended a } \\
\text { regional Train the Trainer program to } \\
\text { coordinate Code training at the village } \\
\text { or community level with a focus on the } \\
\text { walkabout sawmill style of operation. } \\
\text { Trainers to conduct operation level } \\
\text { based workshops on required } \\
\text { practices. May utilise demonstration } \\
\text { forest where available. }\end{array}$ & \\
& \\
&
\end{tabular}




\section{Strategy 4}

\section{Encourage the Development and Implementation of National Codes Based on the Asia-Pacific Code}

While the Code of Practice for Forest Harvesting in Asia-Pacific is a comprehensive document for the forests in the region, most countries will wish to develop national codes of practice which are tailormade to their particular situations. The technical content in the Code will form the basis of the national codes with variations in terminology and techniques made to suit the particular locations.

\begin{tabular}{|c|c|c|}
\hline Objectives & Actions & Outcomes \\
\hline $\begin{array}{l}\text { Create a broad } \\
\text { awareness of the } \\
\text { Code and } \\
\text { implementation } \\
\text { strategy at a national } \\
\text { level. }\end{array}$ & $\begin{array}{l}\text { Progression of the actions detailed in } \\
\text { Strategy } 2 \text {. } \\
\text { Repeat country visits by the appointed } \\
\text { Code implementation officer in an } \\
\text { awareness role. These will act to } \\
\text { educate and create awareness of the } \\
\text { processes occurring at the regional } \\
\text { level and encourage similar actions at } \\
\text { a national level. }\end{array}$ & $\begin{array}{l}\text { Key stakeholder bodies aware and } \\
\text { ready to participate in Code } \\
\text { implementation and then in } \\
\text { development and implementation of a } \\
\text { national code. } \\
\text { - Increased positive and proactive } \\
\text { environment within which to achieve } \\
\text { change. }\end{array}$ \\
\hline $\begin{array}{l}\text { To generate country- } \\
\text { level acceptance of the } \\
\text { need for national codes. }\end{array}$ & $\begin{array}{l}\text { Development of a national stakeholder } \\
\text { body including Department of Forestry, } \\
\text { other relevant governmental agencies, } \\
\text { industry organisations, NGOs and } \\
\text { (where appropriate) landowner } \\
\text { representatives to act as a steering } \\
\text { committee for the process of Code } \\
\text { development and implementation. The } \\
\text { Code implementation officer may be a } \\
\text { part of this committee to assist in } \\
\text { facilitating the process and provide } \\
\text { indications as to successful practices } \\
\text { used to achieve implementation in } \\
\text { other countries. } \\
\text { Review by the stakeholder body of the } \\
\text { Asia-Pacific Code and its role in } \\
\text { further developing the country's forest } \\
\text { management practices. }\end{array}$ & $\begin{array}{l}\text { Increased country-level acceptance } \\
\text { of the Code. } \\
\text { - Better understanding among } \\
\text { stakeholders of the requirements of a } \\
\text { code of practice. }\end{array}$ \\
\hline $\begin{array}{l}\text { Improvement of the } \\
\text { current guidelines for } \\
\text { forest management } \\
\text { through the } \\
\text { development of a code. }\end{array}$ & $\begin{array}{l}\text { Restructuring of the Asia-Pacific Code } \\
\text { by the Forestry Department to produce } \\
\text { a draft national code of practice for } \\
\text { presentation to the national } \\
\text { stakeholder body. } \\
\text { Use of the Asia-Pacific Code by } \\
\text { Pacific countries to refine their existing } \\
\text { codes. } \\
\text { Trialing of the draft code on a small- } \\
\text { scale basis with an appropriate } \\
\text { industry group. } \\
\text { Changes made to the draft national } \\
\text { code based on the industry trial and } \\
\text { feedback from stakeholder groups. } \\
\text { Acceptance of the draft code by the } \\
\text { stakeholder steering committee. } \\
\text { Release of the national code of } \\
\text { practice for forest harvesting. }\end{array}$ & $\begin{array}{l}\text { - Generation of a draft national code } \\
\text { which is appropriate and accepted by } \\
\text { the country. } \\
\text { - Performance testing of the code } \\
\text { allowing refinements as required. } \\
\text { - Development of the first } \\
\text { demonstration forest area. } \\
\text { A national code of practice for forest } \\
\text { harvesting for each APFC country } \\
\text { based on the Code of Practice for } \\
\text { Forest Harvesting in Asia-Pacific. }\end{array}$ \\
\hline
\end{tabular}




\begin{tabular}{|c|c|c|}
\hline Objectives & Actions & Outcomes \\
\hline $\begin{array}{l}\text { To generate a strategy } \\
\text { whereby a national code } \\
\text { can be implemented. }\end{array}$ & $\begin{array}{l}\text { Development of a national } \\
\text { framework, which includes all } \\
\text { stakeholder groups for } \\
\text { implementation of the national or } \\
\text { where appropriate regional code. } \\
\text { Coordination of training institutions } \\
\text { by the steering committee to make } \\
\text { appropriate changes to course } \\
\text { curriculum to include training on the } \\
\text { Code and at a later date } \\
\text { competency-based courses. } \\
\text { Calls through APFC and other } \\
\text { agencies for donor support to assist } \\
\text { in funding the implementation } \\
\text { strategy. } \\
\text { Development of a training program } \\
\text { structure for implementation of the } \\
\text { Code. This should utilise the } \\
\text { trainees from the regional Trainer } \\
\text { training programs as teaching staff } \\
\text { and tie in with the actions detailed in } \\
\text { Strategy } 3 \text {. }\end{array}$ & $\begin{array}{l}\text { - A framework for implementation of } \\
\text { the national code. } \\
\text { - Funding assistance to support the } \\
\text { implementation program. } \\
\text { - A training program to commence } \\
\text { implementation. }\end{array}$ \\
\hline
\end{tabular}




\section{Strategy 5}

\section{Establishment of Demonstration and Training Forests}

If seeing is believing, then learning by doing will provide the basis for improved knowledge uptake. The purpose of the demonstration forests is twofold. First it enables trainees to actually conduct planning, pre-harvest works, carry out the operation and complete a rehabilitation program in an educational environment. Secondly it provides a visual example of a 'good' harvesting operation for others visiting the site. This becomes a very powerful teaching and demonstration tool when undertaken in a forest that is similar to that experienced in a normal work environment.

\begin{tabular}{|c|c|c|}
\hline Objectives & Actions & Outcomes \\
\hline $\begin{array}{l}\text { To establish a series of } \\
\text { appropriately located } \\
\text { demonstration sites in } \\
\text { all significant forest } \\
\text { types within each sub- } \\
\text { region for ease of } \\
\text { accessibility. }\end{array}$ & $\begin{array}{l}\text { - Selection of appropriate easily } \\
\text { accessed sites within each forest type } \\
\text { of each sub-region for establishment of } \\
\text { demonstration forests. } \\
\text { - Planning for and harvesting of sites in } \\
\text { compliance with the Code and other } \\
\text { appropriate guidelines using a willing } \\
\text { industry organisation or training } \\
\text { institution to harvest the area. } \\
\text { - Development of community or village- } \\
\text { based demonstration forests by NGO } \\
\text { community-based projects. } \\
\text { - Post harvest rehabilitation in } \\
\text { conformance with Code. } \\
\text { Monitoring and auditing of the site to } \\
\text { ensure operation conducted in } \\
\text { compliance with the Code and to } \\
\text { provide a record of activity over time. } \\
\text { Continue demonstration operations in } \\
\text { the area. }\end{array}$ & $\begin{array}{l}\text { Provision of appropriate areas within } \\
\text { each sub-region and forest type for } \\
\text { establishment of demonstration } \\
\text { forests. } \\
\text { - Development of a select trained team } \\
\text { of operators and supervisors with } \\
\text { experience in harvesting according to } \\
\text { the Code and the ability to train } \\
\text { others. } \\
\text { Demonstration forest sites } \\
\text { established for the education of } \\
\text { interested parties, managers, } \\
\text { operators, landowners and trainees. } \\
\text { - A variety of sites which show the } \\
\text { results of Code application across a } \\
\text { series of time periods. }\end{array}$ \\
\hline $\begin{array}{l}\text { To improve the } \\
\text { understanding of } \\
\text { managers and operators } \\
\text { about what can be } \\
\text { achieved through } \\
\text { compliance with the } \\
\text { code by involving them } \\
\text { in demonstration forest } \\
\text { development. }\end{array}$ & $\begin{array}{l}\text { - Selection of key industry and forestry } \\
\text { stakeholders to take part in } \\
\text { development of the demonstration } \\
\text { forest. } \\
\text { - Awareness field days (after completion } \\
\text { of operations) with relevant key } \\
\text { stakeholders. } \\
\text { Development of a training curriculum } \\
\text { by the Code implementation officer to } \\
\text { take industry and forestry personnel } \\
\text { through the process used to implement } \\
\text { the Code in the demonstration forest. }\end{array}$ & $\begin{array}{l}\text { - A small highly trained team with } \\
\text { experience in harvesting according to } \\
\text { the Code and the ability to train others. } \\
\text { - A larger group of experienced trainers. } \\
\text { Awareness within the industry, forestry } \\
\text { department and other stakeholder } \\
\text { organisations of the required actions } \\
\text { and results of harvesting according to } \\
\text { the Code. } \\
\text { Accredited operators who have shown } \\
\text { an ability to plan and implement an } \\
\text { operation to the Code required level. }\end{array}$ \\
\hline $\begin{array}{l}\text { Support testing of } \\
\text { practices that may be } \\
\text { new to a country. }\end{array}$ & $\begin{array}{l}\text { New practices to be implemented } \\
\text { when developing demonstration } \\
\text { forest. }\end{array}$ & $\begin{array}{l}\text { Understanding of new practices and } \\
\text { the results of their usage among } \\
\text { key stakeholders. }\end{array}$ \\
\hline $\begin{array}{l}\text { Provide a site for long- } \\
\text { term research into better } \\
\text { harvest practices and the } \\
\text { future generation of } \\
\text { Silvicultural } \\
\text { Prescriptions. }\end{array}$ & $\begin{array}{l}\text { Relevant research organisations to } \\
\text { establish long-term trials on } \\
\text { demonstration forest sites. }\end{array}$ & $\begin{array}{l}\text { Better long-term data on best } \\
\text { management processes } \\
\text { Feedback loop for provision of } \\
\text { information and data into the future } \\
\text { and the ongoing refinement of } \\
\text { practices. }\end{array}$ \\
\hline
\end{tabular}




\section{Strategy 6}

\section{Implementation of Monitoring and Auditing Systems}

Monitoring of Code implementation at the ground level is of key importance in determining the success or failure of the Code implementation program. It is essential that an initial audit be carried out to provide a baseline for comparison in the future (this can be on a regional, sub-regional or national level). It is then expected that it will be up to a year before the effects of the training programs will begin to be observed at the operational level. Follow-up monitoring will assess the level of compliance being achieved. This level can then be progressively raised over time as the Code is fully implemented.

\begin{tabular}{|c|c|c|}
\hline Objectives & Actions & Outcomes \\
\hline $\begin{array}{l}\text { To increase the } \\
\text { understanding of how to } \\
\text { carry out planning for and } \\
\text { implementation of } \\
\text { operational monitoring } \\
\text { and auditing programs. }\end{array}$ & $\begin{array}{l}\text { Incorporate monitoring and auditing } \\
\text { as an important component of all sub- } \\
\text { regional and national workshops, } \\
\text { including, where possible, practical } \\
\text { field activities using these systems. }\end{array}$ & $\begin{array}{l}\text { A trained group of people with the } \\
\text { knowledge to teach others and to } \\
\text { establish and run a monitoring and } \\
\text { auditing program for forest } \\
\text { harvesting operations. }\end{array}$ \\
\hline $\begin{array}{l}\text { To improve the quality of } \\
\text { forest harvesting } \\
\text { operations on a national } \\
\text { level through effective } \\
\text { monitoring and auditing } \\
\text { practices. }\end{array}$ & $\begin{array}{l}\text { - A national baseline audit to be } \\
\text { carried out to determine current } \\
\text { operating standards. } \\
\text { - New national minimum compliance } \\
\text { levels to be determined and a date } \\
\text { set for achievement of new levels. } \\
\text { - Development or reinforcement of an } \\
\text { effective hierarchical structure within } \\
\text { forest departments to allow } \\
\text { monitoring and auditing to occur in } \\
\text { an efficient and effective manner. } \\
\text { - Monitoring program to commence } \\
\text { with on ground support from key } \\
\text { Forestry Department staff. } \\
\text { - First compliance audit to assess } \\
\text { operational standards against the } \\
\text { specified predetermined standards. } \\
\text { - New national compliance levels set. } \\
\text { - Ongoing monitoring and auditing } \\
\text { with the annual generation of } \\
\text { SMART (specific, measurable, } \\
\text { attainable, relevant and time bound) } \\
\text { objectives to guide future activity. }\end{array}$ & $\begin{array}{l}\text { Definition of standards currently } \\
\text { being achieved nationally by } \\
\text { industry operations. } \\
\text { A set of revised standards } \\
\text { outlining the level by which } \\
\text { operations are expected to } \\
\text { improve in a given time frame. } \\
\text { Trained and effective supervisors } \\
\text { who feel well supported and are } \\
\text { competent at their tasks. } \\
\text { Determination of the level of } \\
\text { compliance achieved and the } \\
\text { effectiveness of the Code } \\
\text { implementation program to date. } \\
\text { A new and realistic set of national } \\
\text { benchmarks for the next } \\
\text { compliance audit. } \\
\text { An ongoing monitoring and } \\
\text { auditing program. }\end{array}$ \\
\hline
\end{tabular}




\section{Strategy 7}

\section{Collation of Past and Present Research Results Allowing Development of Appropriate Research Activities and Directions in Support of Sustainable Forest Management}

A great deal of research has been undertaken related to improved forest management and in particular timber harvesting. Prior to undertaking further research, an inventory needs to be carried out and a needs analysis completed for the clients to ascertain where future research should be aimed.

\begin{tabular}{|c|c|c|}
\hline Objectives & Actions & Outcomes \\
\hline $\begin{array}{l}\text { To improve knowledge of } \\
\text { the cost and benefits of } \\
\text { implementing the Code of } \\
\text { Practice for Forest } \\
\text { Harvesting in Asia-Pacific } \\
\text { and other principles and } \\
\text { practices for forest } \\
\text { harvesting, specifically RIL } \\
\text { Guidelines. }\end{array}$ & $\begin{array}{l}\text { Determination of past and existing } \\
\text { research projects and identification of } \\
\text { their suitability to cover existing } \\
\text { information requirements for Code } \\
\text { implementation. } \\
\text { - Determination of gaps in current } \\
\text { research and development of a } \\
\text { program for future research } \\
\text { requirements. } \\
\text { Application through APFC and other } \\
\text { bilateral and donor organisations for } \\
\text { funding on a project-specific basis. } \\
\text { The existing APFC ad hoc Working } \\
\text { Group to co-ordinate funding, } \\
\text { determine project structures and } \\
\text { timing and ensure that results are } \\
\text { made available to all stakeholders. }\end{array}$ & $\begin{array}{l}\text { A wider availability of information } \\
\text { and support for the introduction of } \\
\text { the Code of Practice for Forest } \\
\text { Harvesting in Asia-Pacific and other } \\
\text { principles and practices for forest } \\
\text { harvesting including RIL Guidelines. } \\
\text { Industry and other stakeholder } \\
\text { groups better informed on the cost } \\
\text { and benefits associated with } \\
\text { implementation of the Code of } \\
\text { Practice for Forest Harvesting in } \\
\text { Asia-Pacific and other principles and } \\
\text { practices for forest harvesting. }\end{array}$ \\
\hline $\begin{array}{l}\text { To improve the knowledge } \\
\text { of the silvicultural } \\
\text { requirements of } \\
\text { production forestry to } \\
\text { enhance sustainability. }\end{array}$ & $\begin{array}{l}\text { Within the framework of other bilateral } \\
\text { research projects, establish a specific } \\
\text { set of projects focused on } \\
\text { development of forest type specific } \\
\text { silvicultural prescriptions. This may } \\
\text { be done within the demonstration } \\
\text { forest program. }\end{array}$ & $\begin{array}{l}\text { Improved information to support the } \\
\text { introduction of silvicultural } \\
\text { prescriptions in line with the forest's } \\
\text { biological capacity. } \\
\text { - Clarification of appropriate silvicultural } \\
\text { activities and their associated costs. }\end{array}$ \\
\hline $\begin{array}{l}\text { To improve the } \\
\text { knowledge of the impacts } \\
\text { of different policies and } \\
\text { societal trends on } \\
\text { secondary production } \\
\text { forests to enhance their } \\
\text { sustainability. }\end{array}$ & $\begin{array}{l}\text { Within the framework of other bilateral } \\
\text { research projects, establish a specific } \\
\text { set of projects focused on determining } \\
\text { impacts on various secondary } \\
\text { production forest types. }\end{array}$ & $\begin{array}{l}\text { Clarification of appropriate } \\
\text { management regimes and their } \\
\text { associated costs. }\end{array}$ \\
\hline
\end{tabular}




\section{Strategy 8}

\section{Further Development and Implementation of Sustainable Forest Management Practices in Asia-Pacific}

The Code of Practice for Forest Harvesting in Asia-Pacific is a valuable document in promoting SFM. However, there are many other aspects involved in the endeavour to achieve the goals of SFM in the forests of Asia-Pacific. This strategy outlines some of those objectives that promote SFM in the region.

\begin{tabular}{|c|c|c|}
\hline Objectives & Actions & Outcomes \\
\hline $\begin{array}{l}\text { To assist policy makers at } \\
\text { the regional level to } \\
\text { develop a regional vision } \\
\text { and strategy for } \\
\text { sustainable forest } \\
\text { management. }\end{array}$ & $\begin{array}{l}\text { The ad hoc Working Group to co- } \\
\text { ordinate development of a long-term } \\
\text { strategy for achieving sustainable } \\
\text { management guidelines other than the } \\
\text { Code. This should include a timetable } \\
\text { for development of Reduced Impact } \\
\text { Logging Guidelines and a commitment } \\
\text { to forest type-based Silvicultural } \\
\text { Prescriptions by member countries on a } \\
\text { sub-regional basis. } \\
\text { - Continued support from the APFC for } \\
\text { other SFM initiatives throughout the } \\
\text { region such as RILNET and the recently } \\
\text { submitted joint proposal to ITTO through } \\
\text { APFC, Indonesia and Australia. }\end{array}$ & $\begin{array}{l}\text { A timetable for the development and } \\
\text { implementation of support guidelines } \\
\text { that complement the Code of } \\
\text { Practice for Forest Harvesting in } \\
\text { Asia-Pacific. } \\
\text { Long-term regional plans by the } \\
\text { APFC member countries to institute } \\
\text { sustainable forest management. } \\
\text { Coordination of all agencies to work } \\
\text { towards the same common goal. }\end{array}$ \\
\hline $\begin{array}{l}\text { To assist policy makers } \\
\text { at the national level to } \\
\text { develop a national vision } \\
\text { and strategy for } \\
\text { sustainable forest } \\
\text { management. }\end{array}$ & $\begin{array}{l}\text { Through the APFC focal points, co- } \\
\text { ordinate the development of clear policy } \\
\text { at departmental level aimed at instituting } \\
\text { RIL Guidelines and Silvicultural } \\
\text { Prescriptions based on the APFC's } \\
\text { guidelines and in-country research. } \\
\text { This policy should indicate that the } \\
\text { national code is only an element leading } \\
\text { to sustainable forest management. }\end{array}$ & $\begin{array}{l}\text { A coordinated long-term national plan } \\
\text { by APFC member countries to institute } \\
\text { sustainable forest management } \\
\text { practices. }\end{array}$ \\
\hline $\begin{array}{l}\text { To develop regional RIL } \\
\text { Guidelines designed to } \\
\text { complement the Code of } \\
\text { Practice for Forest } \\
\text { Harvesting in Asia- } \\
\text { Pacific. }\end{array}$ & $\begin{array}{l}\text { The ad hoc Working Group of the } \\
\text { APFC to seek donor support for } \\
\text { development of RIL Guidelines to } \\
\text { support the Code of Practice for Forest } \\
\text { Harvesting in Asia-Pacific. } \\
\text { A tender to be let for development of } \\
\text { the regional RIL Guidelines and } \\
\text { presentation of a draft to the focal } \\
\text { points of the member countries for } \\
\text { comment before acceptance by the ad } \\
\text { hoc Working Group. }\end{array}$ & $\begin{array}{l}\text { - Regional RIL Guidelines applicable to } \\
\text { all APFC member countries and } \\
\text { supporting the Code of Practice for } \\
\text { Forest Harvesting in Asia-Pacific. }\end{array}$ \\
\hline $\begin{array}{l}\text { To develop forest type- } \\
\text { specific sub-regional } \\
\text { Silvicultural } \\
\text { Prescriptions. }\end{array}$ & $\begin{array}{l}\text { APFC Working Group to co-ordinate an } \\
\text { analysis determining the number and } \\
\text { approximate location of production } \\
\text { management forest types in the Asia- } \\
\text { Pacific. } \\
\text { APFC Working Group to be responsible } \\
\text { for coordination of available information } \\
\text { and development of sub-regional } \\
\text { Silvicultural Prescriptions. } \\
\text { APFC Working Group to set a timeline } \\
\text { for implementation of Silvicultural } \\
\text { Prescriptions. }\end{array}$ & $\begin{array}{l}\text { Broad forest type analysis detailing } \\
\text { location and forest type across the } \\
\text { APFC member countries. } \\
\text { - Collation and sharing of data allowing } \\
\text { development of effective Silvicultural } \\
\text { Prescriptions. } \\
\text { - Implementation and revision of } \\
\text { Silvicultural Prescriptions. }\end{array}$ \\
\hline
\end{tabular}




\section{Responsibilities and Timing}

The implementation of the Regional Strategy will involve appropriate actions by all stakeholders. These include:

- Government

- Concession holders

- Landowners

- Relevant NGOs

- International Organisations (i.e. forestry, forest industry, forest research and forest conservation)

- Bilateral and multilateral donors

The governments of the member countries of APFC will have a major role to play in such actions, particularly through their respective forest departments. However, the private sector will have the primary role for implementation and development of implementation systems. A summary of the priorities and those responsible for the specific actions is presented in Table 5.1. A suggested time frame is given under the headings immediate (within 2 years), mid-term ( $2-5$ years) and long-term (5-10 years).

To achieve implementation of the Code of Practice for Forest Harvesting in Asia-Pacific actions need to be undertaken at the regional, national and local levels. Table 5.1 deals mainly with actions at the regional and national levels. Finer detail at the local level will follow once the appropriate national frameworks and directions are set.

Table 5.1. Responsibilities and Timing for the Implementation of the Regional Strategy

\begin{tabular}{|c|c|c|c|}
\hline Institution & Immediate (Within 2 years) & Mid-Term (2-5 years) & Long-Term (5-10 years) \\
\hline APFC & $\begin{array}{l}\text { - Release a statement supporting } \\
\text { the development of national } \\
\text { codes at the Eighteenth Session } \\
\text { of the APFC. } \\
\text { - Formally launch the Code of } \\
\text { Practice for Forest Harvesting in } \\
\text { the Asia-Pacific and the } \\
\text { Regional Implementation } \\
\text { Strategy at the Eighteenth } \\
\text { Session of the APFC. } \\
\text { - Ad hoc Working Group to } \\
\text { coordinate distribution of the } \\
\text { Code and Regional Strategy } \\
\text { throughout all member countries } \\
\text { and to as many stakeholder } \\
\text { bodies as possible. } \\
\text { - Funding to be sought for a Code } \\
\text { implementation officer. } \\
\text { - Ad hoc Working Group to seek } \\
\text { and employ a suitably qualified } \\
\text { person as the Code } \\
\text { implementation officer. } \\
\text { - The ad hoc Working Group and/ } \\
\text { or the Code implementation } \\
\text { officer to facilitate the formal } \\
\text { launch of the Code in each } \\
\text { member country. }\end{array}$ & $\begin{array}{l}\text { - Code implementation officer } \\
\text { to set awareness and } \\
\text { training priorities under the } \\
\text { jurisdiction of the ad hoc } \\
\text { Working Group. } \\
\text { - APFC to seek and direct } \\
\text { support funds for national } \\
\text { code implementation. } \\
\text { - Ad hoc Working Group to } \\
\text { provide and/or direct funds } \\
\text { for research requirements as } \\
\text { previously determined. } \\
\text { - APFC body to coordinate the } \\
\text { development of regional } \\
\text { reduced impact harvesting } \\
\text { guidelines. }\end{array}$ & $\begin{array}{l}\text { - Continue to direct policy and } \\
\text { research as required. }\end{array}$ \\
\hline
\end{tabular}


Table 5.1. (Continued) Responsibilities and Timing for the Implementation of the Regional Strategy

\begin{tabular}{|c|c|c|c|}
\hline Institution & Immediate (Within 2 years) & Mid-Term (2-5 years) & Long-Term (5-10 years) \\
\hline & $\begin{array}{l}\text { Obtain funds to be allocated at } \\
\text { the discretion of the ad hoc } \\
\text { Working Group to support both } \\
\text { regional and national code } \\
\text { implementation activities. } \\
\text { - Ad hoc Working Group or } \\
\text { another selected body to } \\
\text { commence examining research } \\
\text { activities to date. } \\
\text { - Ensure that any implemented } \\
\text { training, awareness or research } \\
\text { programs operate within the } \\
\text { frameworks already created by } \\
\text { other regional and bilateral } \\
\text { programs. }\end{array}$ & & \\
\hline $\begin{array}{l}\text { National } \\
\text { Forest } \\
\text { Ministries }\end{array}$ & $\begin{array}{l}\text { - Support the release of the Code } \\
\text { of Practice for Forest Harvesting } \\
\text { in the Asia-Pacific and the } \\
\text { Regional Strategy for Develop- } \\
\text { ment and Implementation of the } \\
\text { Code of Practice for Forest } \\
\text { Harvesting in Asia-Pacific. } \\
\text { - Evaluate and refine national } \\
\text { policy and/or legislation to } \\
\text { formally adopt the Code. } \\
\text { - Coordinate development of } \\
\text { individual country-based codes } \\
\text { and where applicable forest } \\
\text { type-based codes on a sub- } \\
\text { regional level. } \\
\text { - Develop an implementation } \\
\text { schedule with defined criteria } \\
\text { and timings for enforcement. } \\
\text { - Commence planning and } \\
\text { development of demonstration } \\
\text { forests. } \\
\text { - Attend regional Train the Trainer } \\
\text { programs. } \\
\text { - Develop own in-country trainer } \\
\text { training program. } \\
\text { - Develop schedule and } \\
\text { commence in-country } \\
\text { implementation training } \\
\text { programs. } \\
\text { - Ensure an effective } \\
\text { departmental structure exists to } \\
\text { allow monitoring and auditing to } \\
\text { occur. } \\
\text { audit to allow setting of initial } \\
\text { program target levels. } \\
\text { Develop a system of } \\
\text { enforcement for companies who } \\
\text { fail to comply. }\end{array}$ & $\begin{array}{l}\text { - Follow implementation } \\
\text { schedule with regular review } \\
\text { of progress and adjustment } \\
\text { as required. } \\
\text { - Commence monitoring and } \\
\text { evaluation program with } \\
\text { comparison against baseline } \\
\text { levels. } \\
\text { - Implement demonstration } \\
\text { forests. } \\
\text { - Coordinate testing of } \\
\text { Reduced Impact Logging } \\
\text { procedures. } \\
\text { - Commence development of } \\
\text { an operator accreditation } \\
\text { program. } \\
\text { - Target for full implementation } \\
\text { of the Code of Practice for } \\
\text { Forest Harvesting in the Asia- } \\
\text { Pacific or the national code } \\
\text { by the end of this period. }\end{array}$ & $\begin{array}{l}\text { Continue monitoring and } \\
\text { auditing program with } \\
\text { provision of regular } \\
\text { feedback to companies at } \\
\text { both supervisor and } \\
\text { operator levels. } \\
\text { - Removal of operations that } \\
\text { have continually failed to } \\
\text { comply with the } \\
\text { predetermined standards to } \\
\text { be achieved in Code } \\
\text { implementation. } \\
\text { - Evaluation of Silvicultural } \\
\text { Prescriptions as developed } \\
\text { through the research } \\
\text { program. } \\
\text { - Ongoing monitoring and } \\
\text { reporting on permanent } \\
\text { sample plots. } \\
\text { - Raise the achievement } \\
\text { level required to monitor } \\
\text { programs. } \\
\text { - Implement the operator } \\
\text { accreditation scheme in } \\
\text { conjunction with relevant } \\
\text { training bodies. } \\
\text { - Set time frame for full } \\
\text { operator accreditation. }\end{array}$ \\
\hline
\end{tabular}


Table 5.1. (Continued) Responsibilities and Timing for the Implementation of the Regional Strategy

\begin{tabular}{|c|c|c|c|}
\hline Institution & Immediate (Within 2 years) & Mid-Term (2-5 years) & Long-Term (5-10 years) \\
\hline NGOs & $\begin{array}{l}\text { Support the policy direction and } \\
\text { training program instituted by } \\
\text { APFC and within countries. } \\
\text { Support through the provision of } \\
\text { finance, resources and personnel. } \\
\text { - Develop an NGO-level strategy } \\
\text { for Code and RIL } \\
\text { implementation. This should } \\
\text { focus primarily on small-scale } \\
\text { operations. } \\
\text { Develop training programs } \\
\text { based on the policy direction } \\
\text { that can be applied to village- } \\
\text { based operations. }\end{array}$ & $\begin{array}{l}\text { Provide training for village- } \\
\text { based programs and small } \\
\text { walkabout operations. } \\
\text { - Provide for key training staff to } \\
\text { attend the regional-level Train } \\
\text { the Trainers programs. }\end{array}$ & $\begin{array}{l}\text { Develop operator } \\
\text { accreditation training } \\
\text { through Forestry } \\
\text { Departments and training } \\
\text { bodies for application at the } \\
\text { local community level. }\end{array}$ \\
\hline $\begin{array}{l}\text { Private } \\
\text { Companies }\end{array}$ & $\begin{array}{l}\text { Adopt and implement the Code } \\
\text { of Practice for Forest Harvesting } \\
\text { in the Asia-Pacific where } \\
\text { applicable. } \\
\text { - Provide in-house training in the } \\
\text { Code's field application and } \\
\text { send key staff to regional and } \\
\text { national training programs. } \\
\text { - Work with institutional bodies to } \\
\text { look at the cost benefits that can } \\
\text { be achieved through utilisation } \\
\text { of new practices. }\end{array}$ & $\begin{array}{l}\text { Adopt and implement a } \\
\text { country-specific code when } \\
\text { developed to replace the } \\
\text { Code of Practice for Forest } \\
\text { Harvesting in the Asia-Pacific. } \\
\text { - Alter practices at all levels to } \\
\text { meet new Code guidelines. } \\
\text { - Commence the process of } \\
\text { self-auditing operations. } \\
\text { - Trial Silvicultural Prescriptions } \\
\text { with Forestry Department and } \\
\text { research bodies. } \\
\text { - Adopt the Reduced Impact } \\
\text { Harvesting Guidelines. } \\
\text { Work with Forestry Ministry } \\
\text { and training institutions to } \\
\text { develop operator accreditation } \\
\text { programs. } \\
\text { - Fund industry training body. }\end{array}$ & $\begin{array}{l}\text { - Compliance with Code } \\
\text { implementation criteria. } \\
\text { - Convert machinery fleet to } \\
\text { comply with the philosophy } \\
\text { of Reduced Impact } \\
\text { Logging. } \\
\text { - Support and undertake } \\
\text { accreditation programs } \\
\text { phasing in mandatory } \\
\text { requirements for operator } \\
\text { accreditation. }\end{array}$ \\
\hline $\begin{array}{l}\text { Research } \\
\text { Organisations }\end{array}$ & $\begin{array}{l}\text { Determination of past and } \\
\text { existing projects and } \\
\text { organisations and identification } \\
\text { of their suitability to cover } \\
\text { existing information } \\
\text { requirements. } \\
\text { - APFC ad hoc Working Group to } \\
\text { co-ordinate funding, determine } \\
\text { project structures and timing. }\end{array}$ & $\begin{array}{l}\text { Establish a set of projects } \\
\text { focused on determining } \\
\text { impacts on various second- } \\
\text { ary production forests and } \\
\text { the development of forest } \\
\text { type-specific silvicultural } \\
\text { prescriptions. } \\
\text { - Establish projects or harness } \\
\text { existing projects to determine } \\
\text { the costs and benefits of } \\
\text { applying the Code and RIL in } \\
\text { different forest types. }\end{array}$ & $\begin{array}{l}\text { Commence providing } \\
\text { stakeholder bodies with } \\
\text { information on the costs } \\
\text { and benefits of application } \\
\text { of the Code. } \\
\text { - Begin to coordinate } \\
\text { research results to produce } \\
\text { Silvicultural Prescriptions } \\
\text { at a sub-regional level. } \\
\text { - Continue to examine the } \\
\text { stakeholders needs to } \\
\text { ensure that the research } \\
\text { adds value to the } \\
\text { implementation programs. }\end{array}$ \\
\hline $\begin{array}{l}\text { International } \\
\text { Donor } \\
\text { Organisations }\end{array}$ & $\begin{array}{l}\text { Publish the Regional Strategy. } \\
\text { Support the wide-scale } \\
\text { distribution of the Code and the } \\
\text { Regional Strategy to } \\
\text { stakeholder bodies in all } 29 \\
\text { APFC member countries. }\end{array}$ & $\begin{array}{l}\text { Continue to support and fund } \\
\text { regional and national-level } \\
\text { training programs. }\end{array}$ & $\begin{array}{l}\text { APFC ad hoc Working Group } \\
\text { to continue monitoring and } \\
\text { directing implementation } \\
\text { through the focal points. } \\
\text { - Support the training and } \\
\text { implementation programs. }\end{array}$ \\
\hline
\end{tabular}


Table 5.1. (Continued) Responsibilities and Timing for the Implementation of the Regional Strategy

\begin{tabular}{|c|c|c|c|}
\hline Institution & Immediate (Within 2 years) & Mid-Term (2-5 years) & Long-Term (5-10 years) \\
\hline & $\begin{array}{l}\text { Support training programs at the } \\
\text { three levels of implementation, } \\
\text { i.e. policy makers, mid-level } \\
\text { managers and supervisors/ } \\
\text { operators. } \\
\text { - Support for APFC-suggested } \\
\text { funding areas based on the } \\
\text { implementation strategy. } \\
\text { - Provide trainers from APFC } \\
\text { countries or a country with the } \\
\text { skills/expertise appropriate to a } \\
\text { certain area. } \\
\text { - Provide funding for the Code } \\
\text { implementation officer. } \\
\text { - Provide funding to the ad hoc } \\
\text { Working Group to support Code } \\
\text { implementation activities. }\end{array}$ & & $\begin{array}{l}\text { Assist with setting of } \\
\text { long-term criteria and } \\
\text { indicators. }\end{array}$ \\
\hline $\begin{array}{l}\text { All stake- } \\
\text { holders }\end{array}$ & $\begin{array}{l}\text { Work jointly to achieve Code } \\
\text { implementation. } \\
\text { - Provide input to the national } \\
\text { steering committees. } \\
\text { - The national steering } \\
\text { committee to utilise the support } \\
\text { of the APFC and the Code } \\
\text { implementation officer. } \\
\text { - Accept allocated roles within } \\
\text { the national implementation } \\
\text { strategy. } \\
\text { - Proactively participate in } \\
\text { regional and in-country } \\
\text { awareness training. } \\
\text { - Through the steering } \\
\text { committee work towards the } \\
\text { optimal allocation of resources } \\
\text { to achieve the desired } \\
\text { outcomes. }\end{array}$ & $\begin{array}{l}\text { Commence regular reporting } \\
\text { back to the national steering } \\
\text { committee to ensure that the } \\
\text { programs stay 'on track'. }\end{array}$ & \\
\hline
\end{tabular}




\section{Strategy Outcomes}

The outcomes of successfully implementing the actions of this strategy will include:

- improved standard of harvesting operations in production forests in the Asia-Pacific Region allowing sustainable forest harvesting;

- improved health and status of the residual stand and forest environment and societies dwelling in and around the forest;

- positive economic impacts at the local level resulting from increased employment, economic activity and flow on benefits;

- a sustainable and more efficient and competitive forest industry in the region which takes into consideration the social and environmental values of the forest;

- improved institutional capacity and capability of staff and workers in the forest sector in Asia-Pacific;

- enhanced understanding of the impacts of forest harvesting on different forest types, costs and benefits and effects on the societies and economies in the regions and countries where undertaken; and

- recognition of the role production forestry plays, at both the community and concession levels, in its potential to be undertaken as a sustainable land use and to assist with the prevention of further environmental degradation. 


\section{Appendix 1}

\section{Asia-Pacific Forestry Commission Member Countries}

\begin{tabular}{|c|c|c|c|}
\hline \multicolumn{2}{|c|}{ Country } & \multicolumn{2}{|c|}{ Country } \\
\hline 1. & Australia & 16. & Nepal \\
\hline 2. & Bangladesh & 17. & New Zealand \\
\hline 3. & Bhutan & 18. & Pakistan \\
\hline 4. & Cambodia & 19. & Papua New Guinea \\
\hline 5. & China & 20. & Philippines \\
\hline 6. & Fiji & 21. & Portugal \\
\hline 7. & New Caledonia (France) & 22. & Republic of Korea \\
\hline 8. & India & 23. & Samoa \\
\hline 9. & Indonesia & 24. & Solomon Islands \\
\hline 10. & Japan & 25. & Sri Lanka \\
\hline 11. & Lao P.D.R. & 26. & Thailand \\
\hline 12. & Malaysia & 27. & United States of America \\
\hline 13. & Maldives & 28. & Vanuatu \\
\hline 14. & Mongolia & 29. & Vietnam \\
\hline 15. & Myanmar & \multicolumn{2}{|c|}{ Observer member: United Kingdom } \\
\hline
\end{tabular}




\section{Regional Strategy for Implementing the Code of Practice for Forest Harvesting in Asia-Pacific}

\section{Summary}

This document provides suggestions for an overall strategic framework to achieve implementation of the Code of Practice for Forest Harvesting in Asia-Pacific. Once implemented the Code will optimise the benefits offered by the region's natural production forests and contribute to their sustainable management for the continuing benefit of the community as a whole.

The goals and objectives of this Regional Strategy are expressed as eight strategies for implementation.

1. Encourage appropriate public and political support for implementation of the Code.

2. Develop awareness and support for the Code at the regional and national policymaking levels by stakeholders.

3. Development of a forest sector that is educated and trained in Code implementation.

4. Encourage the development and implementation of national codes based on the Asia-Pacific Code.

5. Establishment of demonstration and training forests.

6. Implementation of monitoring and auditing systems.

7. Collation of past and present research results allowing development of appropriate research activities and directions in support of sustainable forest management.

8. Further development and implementation of sustainable forest management practices in Asia-Pacific.

A time frame for implementation of the Regional Implementation Strategy has also been detailed. This includes target groups who may be able to take responsibility for components of the implementation program over the projected 10-year time horizon. 


\section{Introduction}

The Asia-Pacific Forestry Commission (APFC) comprises 29 countries from the Asia-Pacific region. Appendix 1 provides a list of those countries. Figure 1.1 shows a location map of the member countries.

Figure 1.1 Asia-Pacific Forestry Commission Member Countries

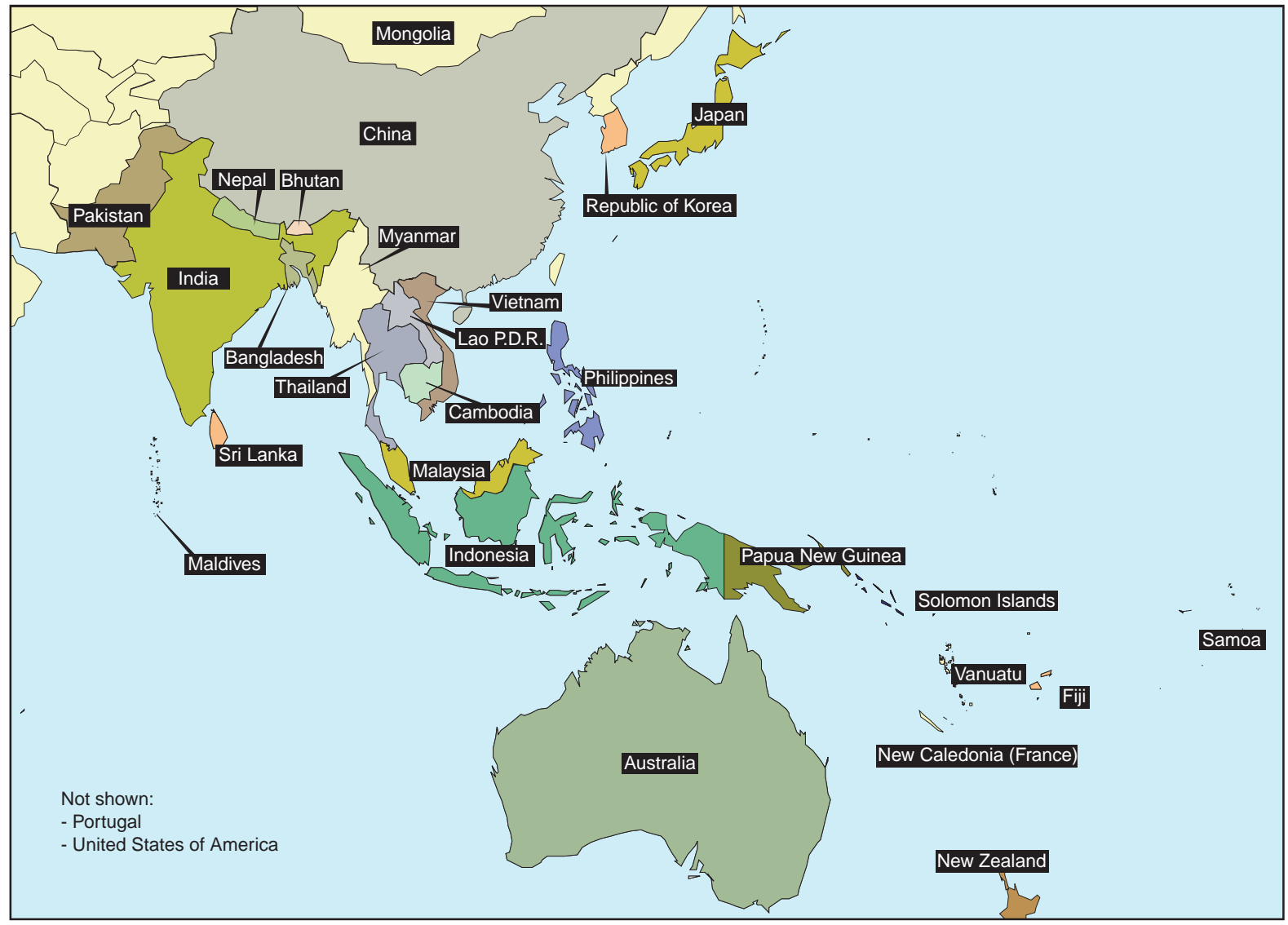

\subsection{Development of a Regional Code of Practice for Forest Harvesting in Asia-Pacific}

The preparation of the Code of Practice for Forest Harvesting in Asia-Pacific (Code) commenced in March 1997 with the first meeting of the APFC ad hoc Working Group on Sustainable Forest Management in Bogor, Indonesia. Participants from APFC member countries agreed on a framework for the Code, including its purpose, scope, coverage and implementation approaches. Development of the AsiaPacific Code began with an extensive review of existing codes throughout Asia-Pacific and other regions around the world. Country visits were then made to Myanmar, Bangladesh and Indonesia where inputs for the Code were obtained. A draft Code was prepared and provided to APFC members prior to a second meeting of the APFC ad hoc Working Group on Sustainable Forest Management in November 1997. The second meeting was attended by 50 representatives from 20 APFC member countries, international organisations, non-governmental organisations (NGOs) and forest industry organisations. The delegates at the meeting reviewed the draft in light of their own national consultations and provided 
further written comments to enable the Code to be tabled for approval at the Seventeenth Session of the APFC held in Indonesia in February 1998.

\subsection{Preparation of the Regional Strategy for Implementing the Code of Practice for Forest Harvesting in Asia-Pacific}

During the Seventeenth Session of the Asia-Pacific Forest Commission, delegates extended and expanded the mandate of the APFC ad hoc Working Group on Sustainable Forest Management to include preparation of a strategy to implement the Code of Practice for Forest Harvesting in Asia-Pacific.

A three-day planning workshop for the APFC ad hoc Working Group on Sustainable Forest Management was convened in September 1998 in Bogor, Indonesia. Participants representing a number of APFC member countries, donors and support organisations attended this meeting. The Working Group provided inputs for the Regional Strategy for Implementing the Code of Practice for Forest Harvesting in AsiaPacific. These inputs were used by Jaakko Pöyry Consulting (Asia-Pacific) for developing a draft of the Regional Strategy under a contract to the Government of Australia (Department of Environment and Department of Agriculture, Fisheries and Forestry - Australia).

The Regional Strategy is designed to outline short and long-term approaches for implementing the Code of Practice for Forest Harvesting in Asia-Pacific with elaboration of sub-regional/country groupings. This draft was distributed to the ad hoc Working Group focal points of the member countries in late 1999 with finalisation of the document after comments in early 2000. 


\section{Need for a Regional Strategy for Implementing the Code of Practice for Forest Harvesting in Asia-Pacific}

\subsection{Background}

The forest area of Asia-Pacific comprises 16\% of the total world forest area of 3.4 billion hectares (Figure 2.1). Asia comprises about $13 \%$ of the world total and Oceania (Pacific) has 3\% of global forest area (Jaakko Pöyry 1997 and FAO 1999).

Figure 2.1 Global Forest Area by Region

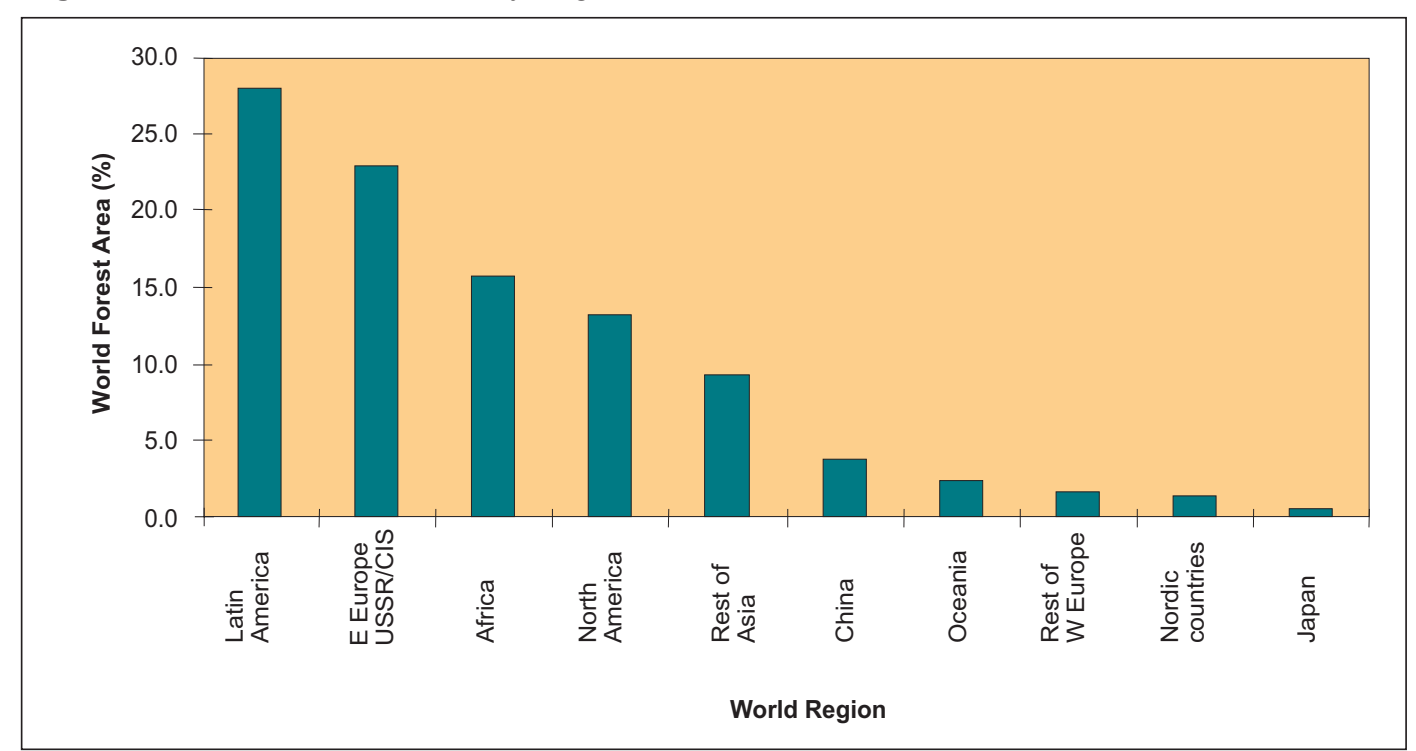

Sources: Jaakko Pöyry 1997 and FAO 1999

Log production continued to grow in Asia-Pacific throughout the 1980s at an annual rate of about 1 million $\mathrm{m}^{3} / \mathrm{a}$ until it peaked in 1989 at 160 million $\mathrm{m}^{3} / \mathrm{a}$. About half of this production was from the tropical hardwood forests of South-East Asia.

The main supply of tropical hardwoods from the Asia-Pacific Region comes from the mixed tropical rainforests in South-East Asia, dominated by the family Dipterocarpaceae. These dipterocarp forests extend in a broad arc from southern Thailand through Sumatra, Peninsular Malaysia, Borneo (Kalimantan, Sarawak, and Sabah) to the Philippines. Seven species of the family occur in Papua New Guinea.

The sawnwood and plywood industries in Japan, Indonesia and Malaysia are major users of tropical hardwood logs and therefore currently rely on these forests. However, with the declining resource, other non-dipterocarp hardwood species are being substituted for plywood production. These include Pometia spp., Calophyllum spp. and Dillenia spp. from Pacific Island countries. There is also an increasing trend toward substitution of tropical hardwoods with softwood timber from plantations of Australia/New Zealand and from the native boreal forests of Russia.

The main areas supplying natural tropical forest logs in Asia-Pacific over the next 15 years will be Kalimantan and Papua in Indonesia and Sarawak in Malaysia; and to a much lesser degree, Papua New Guinea with minor amounts from the Solomon Islands. At the same time, the extensive areas of both hardwood and softwood plantation being established in countries across Asia-Pacific will increase 
production and begin to fill the predicted wood deficit in the region. Large areas of plantation grown expressly to produce sawlogs are already coming on stream in New Zealand and Australia (approximately 3.7 million hectares).

Figure 2.2 provides a comparison of the production of tropical hardwood logs from the major producing countries of South-East Asia and Africa. The tropical countries of Africa are included as much of the volume goes into processing plants in Asia and then on to Japan.

Figure 2.2 Production of Tropical Hardwood Logs from South-East Asia and Africa, selected years 1965 to 2010

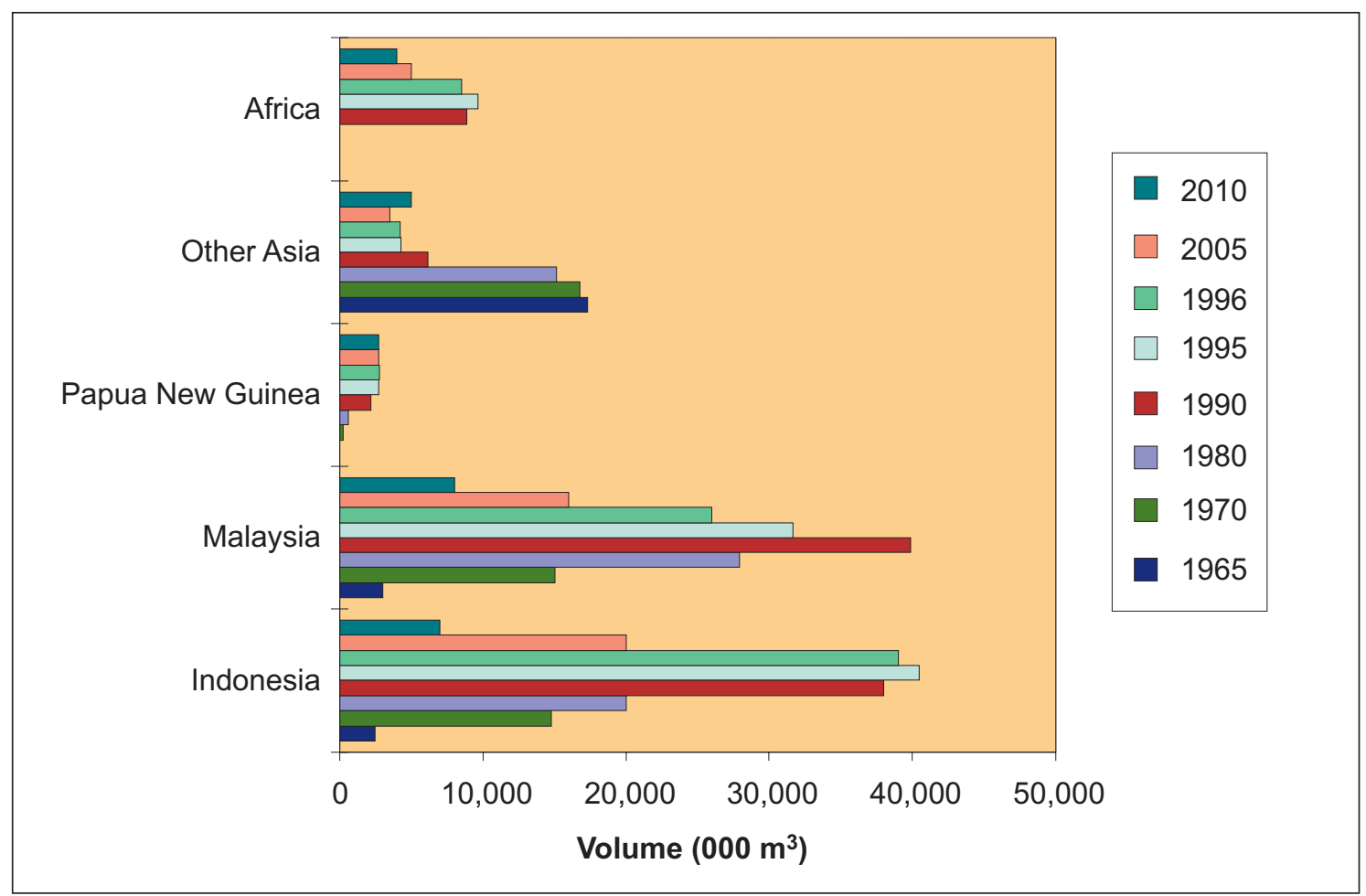

Source: FAO 1997

\subsection{Harvesting Practices}

Most natural forest harvesting operations in Asia-Pacific are carried out using conventional groundbased harvesting techniques. Generally this involves a chainsaw operator carrying out felling and then cross cutting either in the forest or on the landing. A crawler tractor or skidder then extracts trees or logs to a landing for measurement and loading before being carted to the log buyer. While there are variations, such as mechanised falling, animal extraction, hand extraction/loading etc, most operations are of this form. The Code of Practice for Forest Harvesting in Asia-Pacific is therefore targeted at this form of operation, although the principles and practices detailed apply generally to all harvesting operations.

\subsection{Need for a Regional Strategy}

The large volumes of timber being harvested from Asia-Pacific are a significant component of the economies of many countries in the region. These countries rely heavily on this resource and are 
dependent on the ecological and social sustainability of their forests in the long term. Like many tropical forests throughout the world, the region's forests have the potential to provide raw material and other tangible and non-tangible benefits in perpetuity, providing certain changes are made to harvesting practices. A major step in the process of providing for these changes was the preparation of the Code of Practice for Forest Harvesting in Asia-Pacific. The next fundamental component of the process is to prepare a Regional Strategy for implementing the Code for the sustainable management of the remaining production forests.

\subsection{Asia-Pacific Sub-Regions}

The Asia-Pacific region can be divided into sub-regions based on geographic location. This incorporates similarities in forest types, ethnic groups and land tenure systems. The separation into sub-regions also facilitates the development of a Regional Strategy for the implementation of the Code. This subregionalisation allows the grouping of countries with similar forest types and land tenure systems with advantages for developing lower-cost training and awareness programs. Figure 2.3 shows a nominal breakdown of the Asia-Pacific region into four sub-regions: South Asia, South-East Asia, East Asia and the Pacific.

Figure 2.3 The Asia-Pacific Sub-Regions

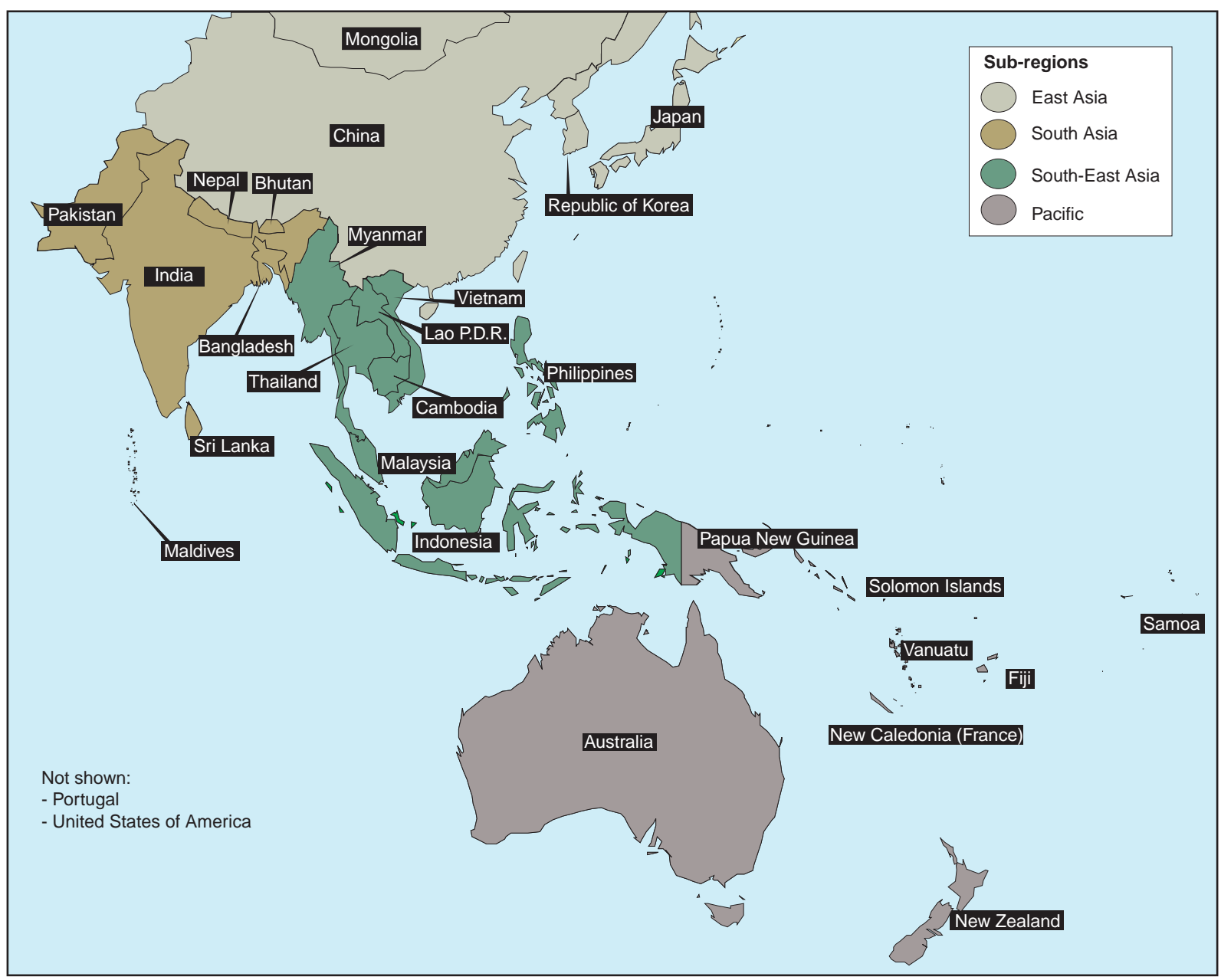


Figure 2.4 includes the nominal groupings of the Asia-Pacific member countries and indicates some of the policy inputs to Code development. It also highlights that the Pacific countries have already developed a 'Code of Conduct for Logging Indigenous Forests in Selected South Pacific Countries'. This document is similar to the Code of Practice for Forest Harvesting in Asia-Pacific, and has provided the template for Pacific countries to develop their own national codes. While Australia and New Zealand are listed in this grouping, the Pacific code was originally designed for tropical hardwood forest and therefore is not fully applicable to either of these countries, or other APFC member countries with non-tropical forests. Both countries have developed and implemented their own codes of practice that are relevant to their forest types and silvicultural regimes.

Figure 2.4 Nominal Groupings of the APFC Member Countries for the Purposes of the Regional Strategy

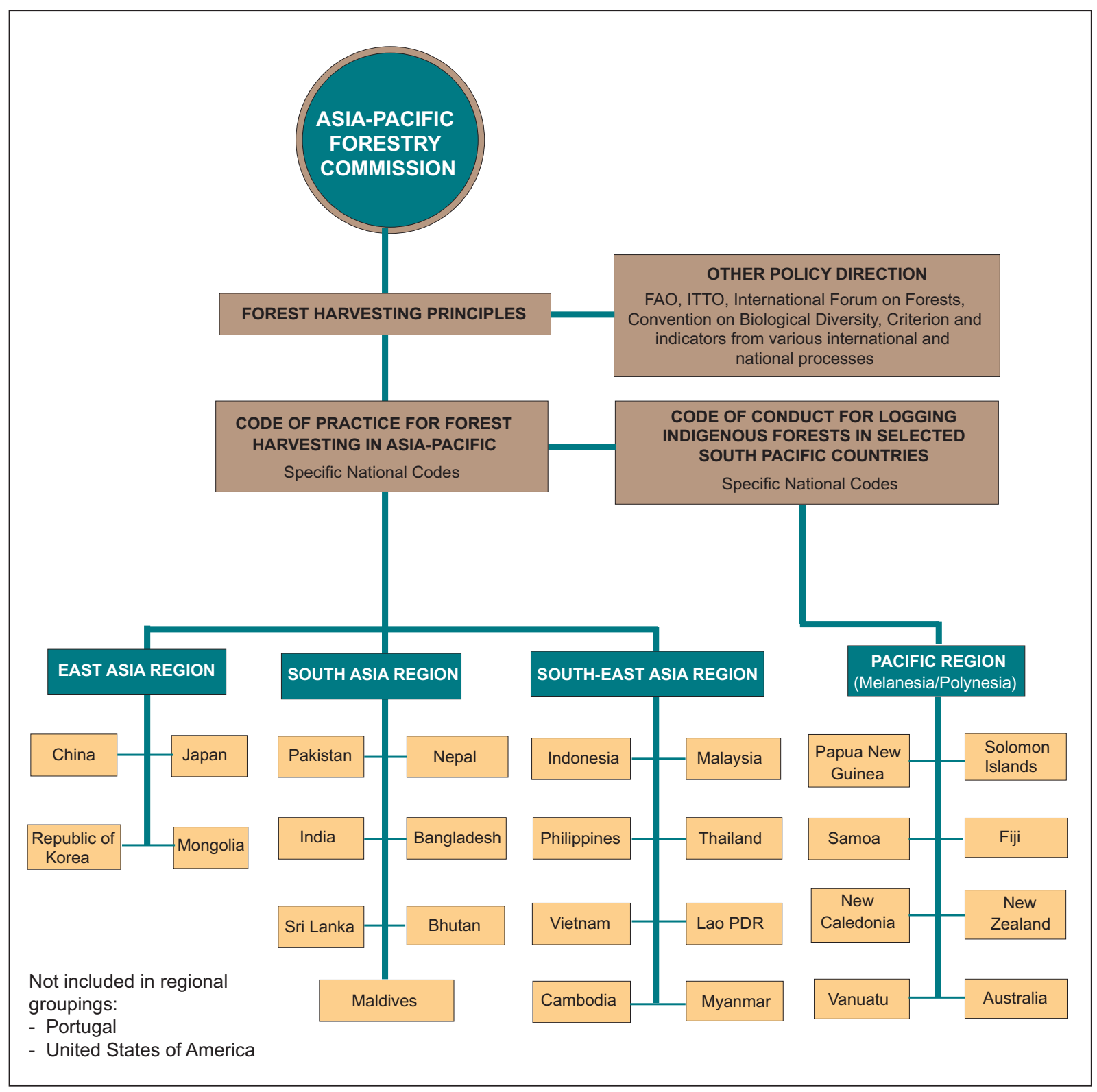




\section{Current Status of Production Forest Management in Asia-Pacific}

APFC countries independently develop and implement a range of forest management practices (Table 3.1). In many cases, countries have a series of guidelines or systems that act in the same way as Codes of Practice, Reduced Impact Harvesting Guidelines etc, or are in the process of developing these management systems. Table 3.1 also provides information on the status of specific elements of sustainable forest management of APFC countries. A demonstration forest refers to a model forest developed specifically for research into improved practices, training and demonstration purposes according to a country's best management practices.

The status of Silvicultural Prescriptions have not been included in Table 3.1. A number of countries in the region have been reviewing their current silvicultural practices and the effect that implementation of these prescriptions have had on the residual stands and actual growth rates. It is recognised that many of the silvicultural prescriptions refer to legislated diameter cutting limits for all species in broad forest types. They are seldom prescriptions developed from research activities designed to assess the biological capacity of the different forests or on an understanding of the ecology of the species to be harvested, or of those to remain in the residual stand. A number of countries in the Pacific, have recognised the need to review their silvicultural practices and have made progress towards revision.

The intended focus of this Regional Strategy is on countries within Asia-Pacific. For this reason Portugal, France, the United Kingdom and the United States of America are not included in Table 3.1. 
Table 3.1 Implementation of Key Elements of Sustainable Forest Management in Asia-Pacific: Country Status

\begin{tabular}{|c|c|c|c|c|c|c|c|}
\hline Sub-Region & Country & Legislation & $\begin{array}{c}\text { National } \\
\text { Forest Policy }\end{array}$ & Code of Practice ${ }^{2}$ & $\begin{array}{l}\text { Reduced Impact } \\
\text { Harvesting Guidelines }\end{array}$ & $\begin{array}{l}\text { Operational Operator } \\
\text { Accreditation }\end{array}$ & $\begin{array}{l}\text { Demonstration } \\
\text { Forests }\end{array}$ \\
\hline \multirow{8}{*}{$\begin{array}{l}\text { Pacific Region } \\
\text { (Melanesia/ } \\
\text { Polynesia) }\end{array}$} & Australia $^{1}$ & $\checkmark$ & $\checkmark$ & $\checkmark$ & States have own Guidelines & $\checkmark$ & $\checkmark$ \\
\hline & Fiji & $\checkmark$ & $\checkmark$ & $\checkmark$ & Developing & Nil & $\checkmark$ \\
\hline & New Caledonia & $\checkmark$ & $\checkmark$ & & Nil & Nil & Nil \\
\hline & New Zealand & $\checkmark$ & $\checkmark$ & $\checkmark$ & Combined with Code & $\checkmark$ & $\checkmark$ \\
\hline & PNG & $\checkmark$ & $\checkmark$ & $\checkmark$ & Planned & Developing & Planned \\
\hline & Samoa & $\checkmark$ & $\checkmark$ & $\checkmark$ & Planned & Nil & Planned \\
\hline & Solomon Islands & $\checkmark$ & $\checkmark$ & $\checkmark$ & Developing & Nil & Planned \\
\hline & Vanuatu & $\checkmark$ & $\checkmark$ & $\checkmark$ & $\checkmark$ & Nil & $\checkmark$ \\
\hline \multirow{9}{*}{$\begin{array}{l}\text { South-East Asia } \\
\text { Region }\end{array}$} & Cambodia & $\checkmark$ & $\checkmark$ & $\checkmark$ & Developing & Nil & Nil \\
\hline & Indonesia & $\checkmark$ & $\checkmark$ & $\checkmark$ & Some Institutions/Companies & Company based & $\checkmark$ \\
\hline & Lao PDR & $\checkmark$ & $\checkmark$ & $\checkmark$ & Developing & Nil & $\checkmark$ \\
\hline & Malaysia $^{1}$ & $\checkmark$ & $\checkmark$ & $\checkmark$ Harvest Guidelines & $\checkmark$ Some States & $\checkmark$ & $\checkmark$ \\
\hline & Maldives & $\checkmark$ & $\checkmark$ & Nil & Nil & Nil & Nil \\
\hline & Myanmar & $\checkmark$ & $\checkmark$ & $\checkmark$ & Developing & Nil & $\checkmark$ \\
\hline & Philippines & $\checkmark$ & $\checkmark$ & Minimal Logging & Minimal Logging & Nil & $\checkmark$ \\
\hline & Thailand & $\checkmark$ & $\checkmark$ & Logging Suspended & Logging Suspended & Nil & $\checkmark$ \\
\hline & Vietnam & $\checkmark$ & $\checkmark$ & $\checkmark$ & Planned & Nil & Nil \\
\hline \multirow[t]{7}{*}{ South Asia Region } & Bangladesh & $\checkmark$ & $\checkmark$ & Planned & Planned & Nil & Nil \\
\hline & Bhutan & $\checkmark$ & $\checkmark$ & Developing & Planned & Nil & Nil \\
\hline & India & $\checkmark$ & $\checkmark$ & Planned & Nil & Nil & Nil \\
\hline & Mongolia & $\checkmark$ & $\checkmark$ & Developing & Nil & Nil & Nil \\
\hline & Nepal & $\checkmark$ & $\checkmark$ & Planned & Some Forest Types & Nil & Nil \\
\hline & Pakistan & $\checkmark$ & $\checkmark$ & Planned & Nil & Nil & Nil \\
\hline & Sri Lanka & $\checkmark$ & $\checkmark$ & Developing & Planned & Nil & Nil \\
\hline \multirow[t]{3}{*}{ East Asia Region } & China & $\checkmark$ & $\checkmark$ & Developing & Planned & Nil & $\checkmark$ \\
\hline & Japan & $\checkmark$ & $\checkmark$ & $\checkmark$ & $\checkmark$ & Nil & Nil \\
\hline & Republic of Korea & $\checkmark$ & $\checkmark$ & Planned & Planned & Nil & Nil \\
\hline
\end{tabular}

${ }^{1}$ State-based forestry management with each state determining its own Codes of Practice and Reduced Impact Logging Guidelines.

2 Some countries in the Pacific are currently reviewing their Codes of Practice. 


\section{Regional Strategy Implementation}

The purpose of this Regional Strategy is to achieve implementation of the Code of Practice for Forest Harvesting in Asia-Pacific. Implementation of this Code will enhance the management of native forests throughout the Region by increasing efficiency of harvesting operations while providing more environmentally sensitive management practices.

Stakeholders in this Regional Strategy include industry, forest departments, NGO bodies and community groups. All will have to work together with a common goal to achieve the changes required at the institutional, policy and operational levels to effectively implement the Code.

This Regional Strategy outlines the actions required by the stakeholders to achieve effective implementation of the Code. The actions detailed include initiatives to improve management of all production forests through improved management systems and institutional development to improve capacity and capability of staff of both the public and private sector organisations. Indirect actions are also included in the strategy, whereby government can create a policy environment in which private sector decisions can benefit the community as a whole.

\subsection{Goals and Objectives}

The overall goal of the Regional Strategy for the Development and Implementation of the Code of Practice for Forest Harvesting in Asia-Pacific is to optimise the benefits offered by the region's natural production forests and to contribute to the sustainable development and management of these forests for the continuing benefit of the communities in the region.

This goal can best be achieved by defined outcomes that meet the following eight strategic objectives:

1. Encouraging appropriate public and political support for implementation of the Code.

2. Developing awareness and support for the Code at the regional and national policy-making levels by stakeholders.

3. Development of a forest sector that is educated and trained in Code implementation.

4. Encouraging the development and implementation of national codes based on the AsiaPacific Code.

5. Establishment of demonstration and training forests.

6. Implementation of monitoring and auditing systems.

7. Collation of past and present research results allowing development of appropriate research activities and directions in support of sustainable forest management.

8. Further development and implementation of sustainable forest management practices in Asia-Pacific. 


\subsection{Institutional Framework}

To foster institutional change, both regionally and nationally within APFC member countries; staff capacity at all levels within and outside government must be addressed in a manner which provides for their needs and empowers them to manage the process of change. Within any institution, staff can generally be divided into four levels (Figure 4.1). The triangle in Figure 4.1 represents one of many organisations, while the box above represents the regional and national policy makers who set the policy directions.

Figure 4.1 Organisational Levels and Key Training Target Groups

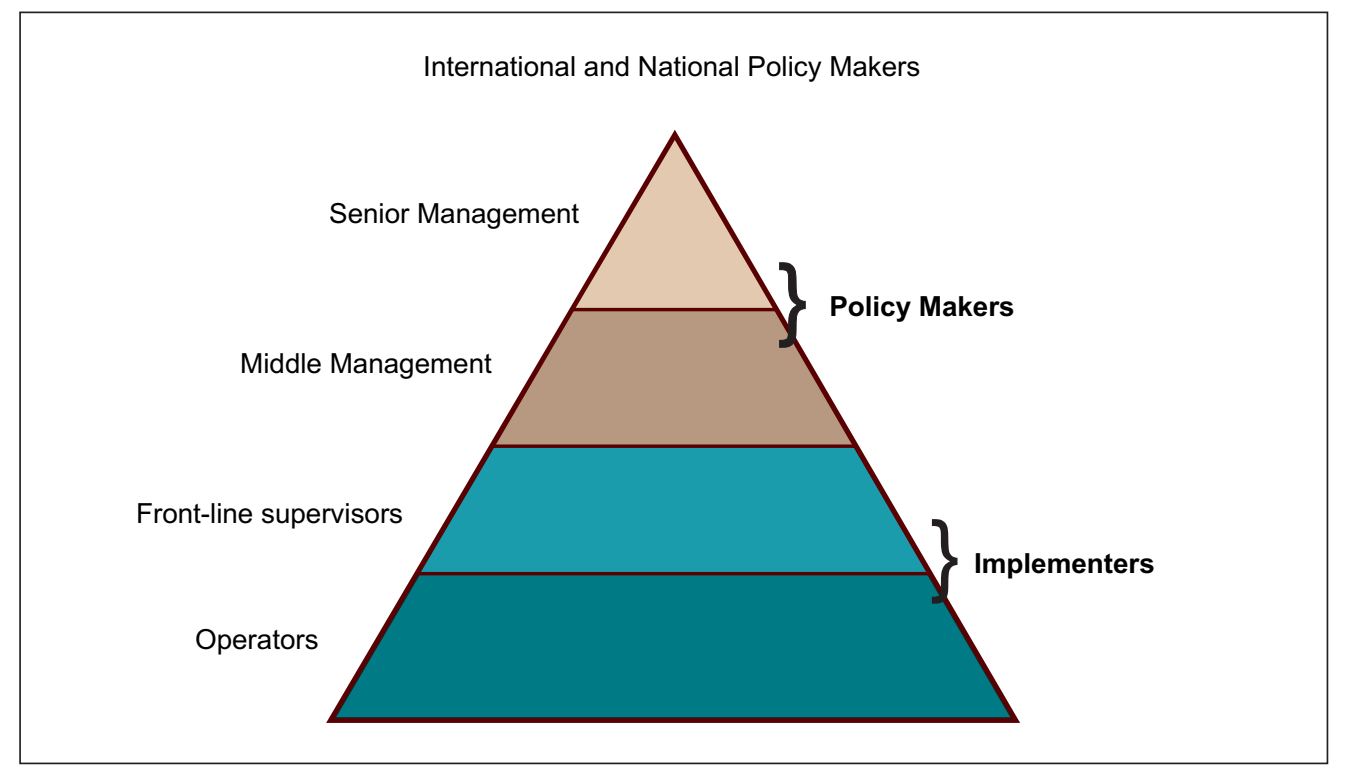

Depending on an organisation's management structure, the triangle shown in Figure 4.1 can be a flat structure with a small number of managers and a large number of operating staff, e.g. typical logging company; or with a more hierarchical structure, e.g. forestry departments. As a general rule, change is instituted at the policy level by senior and middle level management. Middle-level management then has the task of refining policy into implementable structures and actions that can be adopted by staff at the ground level. It is only when staff at all levels of an institution adopt a practice that it truly becomes 'institutionalised'.

To commence this process of institutional change, a number of key change agents and actions are required. Change agents are generally people who are in key positions within an organisation where they have the opportunity to drive change. They must have the ability to transfer information, motivate others and convert policy to a practical level whereby it can be applied.

Initially the drive for change must come from the APFC and other similar bodies through the mechanisms that are outlined in this strategy. It will then be the responsibility of individual countries to take the directions set by the APFC and apply them, first at the policy level and then at the operational level. 


\subsubsection{National Codes of Practice}

The Code of Practice for Forest Harvesting in Asia-Pacific has provided a broad framework for the development of national codes of harvesting practice and/or sets of operational guidelines. It is now the responsibility of individual APFC member countries to take this framework and use it to develop their own national codes and/or sets of guidelines. These codes should be country specific and in some cases may need to be forest type specific. Forest type specific codes may be applicable across a number of countries. For example, mangrove forests occur in many APFC countries (Bangladesh, Malaysia, India, Vietnam) and while the requirements for management of mangrove forests are quite specific to this forest type they also remain relatively similar from country to country. Swamp forest logging and harvesting of high elevation forests are also likely to require forest specific codes.

A number of the APFC countries already have national codes of practice or similar guidelines, particularly among the Pacific member countries. Many of these countries are now reaching a point were their codes/guidelines require revision. The Code of Practice for Forest Harvesting in Asia-Pacific provides a basis on which these countries may decide to further refine their codes.

While this document provides a strategy for implementation of the Code of Practice for Forest Harvesting in Asia-Pacific, it will be necessary for individual countries to develop their own national plans for implementation. It is envisaged that these would be complementary to the broad guidelines of this Regional Strategy in content and timing.

\subsubsection{Awareness and Training}

It is recommended that the initial key element for the implementation of the Code of Practice for Forest Harvesting in Asia-Pacific be a major awareness and training program. This will serve two purposes:

- Help spread the message at all levels within stakeholder groups that the Code of Practice for Forest Harvesting in Asia-Pacific exists and is to be adopted nationally in order to further improve practices.

- Assist with the training of a group of key change agents, providing them with the Train the Trainer skills to train others throughout the APFC region and within their respective countries.

The training program will need to have two target groups:

1. Trainers - The group of specialist training staff who require trainer training skills.

2. Implementers - The main body of an organisation who take the information provided by the trainers and apply it at all levels throughout their respective organisation. Implementers can come from all levels but the focus is on middle-level management and the operators.

A side benefit of the training program is that it will also assist to rapidly spread awareness of the Code.

\section{Training of Trainers}

At the commencement of any institutionalisation program, training of trainers is essential. This is the program that develops the key change agents who then become the catalyst for change at all levels in an organisation. In this case, a Train the Trainer program would have two requirements. Firstly, it would provide the target group of trainers with the skills to teach others effectively. There is considerable difference between talking to a group and effective training. Training should utilise 
adult learning principles, be target group specific and systematically plan and deliver the message in the most interactive way possible. After completion of the initial Train the Trainers program, the group of key change agents should have sufficient teaching skills to allow them to develop their own country-specific training curriculum.

The second element of the Train the Trainers program is to provide participants with a full understanding of what a code of practice is, what it does and how it should be applied operationally so they can communicate this information to others. A pilot regional Train the Trainers program was undertaken in Malaysia during May 1999 with funds provided to the Department of Environment and Heritage and the Department of Agriculture, Forestry and Fisheries - Australia by AusAID. This learning experience has served as the basis for future training programs. A curriculum has now been developed to provide guidance for future workshops of this nature.

\section{Training of Implementers}

Training of implementers could commence once training of trainers is completed. This would generally involve trainers using systematic training techniques to teach three target groups, i.e. policy, middle level and implementers (operators and supervisors). They must make participants aware of the codes (both national, and where applicable, the Asia-Pacific Code), teach the benefits of applying the contents of these documents and make the target groups familiar with the application of the practices at their respective levels. The trainees would then most likely need some practical follow-up support to assist them in converting the training to operational practices.

Operator training needs to be far more practical and specific to the needs of the operator's job task. Awareness of the Code must be included along with the skills to allow compliance, e.g. directional falling. At the upper level of operator training, competency-based programs can be provided and set as a required standard for operators to work in the forest.

At the completion of these programs, follow-up training, intensive monitoring and, where required, penalties for non-compliance should ensure that the Code of Practice for Forest Harvesting in AsiaPacific and/or a national code is implemented according to the timetable developed by individual countries.

\subsubsection{Implementation Guidelines for Codes of Practice}

While the purpose of this strategy is to detail a series of actions to assist APFC countries to implement the Code regionally and develop and fully implement national codes of practice for timber harvesting, this is only one of a number of elements required to improve the standard of forest harvesting in the region. A code sets a series of minimum standards for 'what to do' in a harvesting operation. Experience in the Pacific has shown that two other essential elements are required to truly lift the standard of harvesting practices and ensure that post-harvesting stands remain viable into the future. These are improved silvicultural prescriptions and reduced impact logging guidelines (RIL).

Silvicultural prescriptions should be developed based on a single forest type and the desired postharvest stand structure that must be maintained to enable the forest to remain viable following harvesting. A silvicultural prescription gives the 'why' component of forest management. It should prescribe requirements for potential crop trees, species-specific diameter cutting limits, seed trees, allowable removals per hectare, maximum and minimum percentages of canopy disturbance and post-harvesting activities such as stand improvement. 
RIL guidelines are commonly referred to as the 'how' of forest harvesting. These guidelines are based on the Code and provide the knowledge of how the Code will be implemented. They must be quite specific and measurable, ensuring field application can be monitored for improvements and audited for compliance.

In the future it would be prudent for the APFC to consider providing support for the development of regional sets of Reduced Impact Logging guidelines and a framework for forest type based, sub-regional silvicultural prescriptions ${ }^{1}$. This could be done through a similar process to that used to develop the Code.

\subsection{Opportunities}

The publication of the Code of Practice for Forest Harvesting in Asia-Pacific provides an ideal opportunity for the region to move forward, raising the standard of forest management practices throughout the region. A pilot regional Train the Trainer Workshop on Implementation of the Code of Practice for Forest Harvesting in Asia-Pacific has been completed in Malaysia. Along with a Study Tour to Malaysia, this has commenced the implementation program for the region and provides the first group of change catalysts. With further support, both on national and regional bases, this group will be able to commence the process of institutionalising fundamental changes in forest harvesting practices across the region.

\subsection{Strategic Plan}

Strategies comprise sets of actions that are required to achieve the overall goal. These actions are designed to maximise identified opportunities and to minimise constraints. The eight strategies required to move towards and achieve the main goal have been prepared, together with an indication of the actions required and the expected outcomes.

It should be noted that the strategies are not single entities in themselves, but overlap and are reliant on each other. For example, without political will to move the process forward (Strategy 1), there will be little hope of progressing the other strategies. However, the political will is unlikely to develop without awareness at the regional and national levels (Strategies 2 and 3). It is therefore important that the actions under each strategy are examined as a whole and occur simultaneously if the desired outcomes are to be achieved.

The process of developing a national code is described in the strategies. It should be noted that some countries are likely to take this further to a state, region or province level. For example, each of the six states of Australia has its own code.

These strategies focus on outcomes and are intended to set directions for policy formulation and donor support for funding to achieve region-wide implementation of the Code of Practice for Forest Harvesting in Asia-Pacific. 


\section{Strategy 1}

\section{Encourage Appropriate Public and Political Support for Implementation of the Code}

Ensuring the appropriate policy and legal framework is in place is fundamental to providing the necessary incentives to encourage the contents of the Code to be implemented. For concession owners or those with the rights to manage or utilise a forest, policies need to address the exclusivity or security of the harvesting rights, the transferability of those rights, the divisibility which allows transfers to take place, enforceability and the presence of a free market for the sale of the forest products.

\begin{tabular}{|c|c|c|}
\hline Objectives & Actions & Outcomes \\
\hline $\begin{array}{l}\text { To develop appropriate } \\
\text { legal frameworks and } \\
\text { incentive awareness } \\
\text { based systems to } \\
\text { achieve Code } \\
\text { implementation. }\end{array}$ & $\begin{array}{l}\text { The Forestry Department in conjunction } \\
\text { with other stakeholders to review and } \\
\text { determine potential policy and legislative } \\
\text { changes to achieve Code implementation. } \\
\text { The Forestry Department to analyse } \\
\text { current mechanisms for encouraging } \\
\text { compliance and where required } \\
\text { enforcement of legislation and guidelines } \\
\text { on forestry practice. } \\
\text { - Forestry Department in conjunction with } \\
\text { relevant government departments to } \\
\text { determine the best combination of } \\
\text { incentive, awareness and enforcement } \\
\text { mechanisms to achieve enactment and } \\
\text { enforcement of the Code, e.g. through } \\
\text { legislative requirements, conditions } \\
\text { binding on harvesting licences etc. This } \\
\text { may require drafting of legislation or } \\
\text { development and approval of incentives/ } \\
\text { sanctions for voluntary implementation. } \\
\text { Forestry Department to obtain political } \\
\text { support to implement the best combination } \\
\text { of incentive and legislative based } \\
\text { enforcement mechanisms through the } \\
\text { proposal of legislative and policy changes. }\end{array}$ & $\begin{array}{l}\text { Understanding of the success or } \\
\text { failure of current forest } \\
\text { management guidelines and the } \\
\text { advantages/disadvantages of using } \\
\text { a range of incentives, awareness } \\
\text { techniques and enforcement } \\
\text { mechanisms for Code } \\
\text { implementation. } \\
\text { Development of a legal framework } \\
\text { or a reward-based voluntary } \\
\text { framework for the implementation } \\
\text { of the Code. }\end{array}$ \\
\hline $\begin{array}{l}\text { To prepare the political } \\
\text { environment for } \\
\text { acceptance of and a } \\
\text { proactive stance on } \\
\text { instituting the Code. }\end{array}$ & $\begin{array}{l}\text { The APFC to release a statement formally } \\
\text { supporting the development of national } \\
\text { codes based on the Asia-Pacific Code. } \\
\text { This is to be signed by and circulated to all } \\
\text { member countries. } \\
\text { Within } 2 \text { years of the APFC meeting, a } \\
\text { follow-up meeting to be held on a sub- } \\
\text { regional basis for the Asia groups to } \\
\text { review progress and determine strategies } \\
\text { for overcoming obstacles to this point in } \\
\text { time. } \\
\text { Pacific countries to continue review of } \\
\text { their Pacific Regional Code with findings } \\
\text { on best practices being used to assist Asia } \\
\text { group countries when they reach the } \\
\text { review stage. }\end{array}$ & $\begin{array}{l}\text { - Increased pressure on all countries to } \\
\text { institute forest practices reform } \\
\text { through the Code. } \\
\text { - An environment of acceptance for the } \\
\text { Code by member countries and } \\
\text { generate a clear target for } \\
\text { implementation, e.g. Code } 2001 \\
\text { similar to ITTO's Target } 2000 . \\
\text { - Growing enthusiasm for } \\
\text { institutionalisation of the Code and } \\
\text { assist countries overcome some of the } \\
\text { obstacles encountered through group } \\
\text { workshopping of difficulties } \\
\text { encountered to this point in time. } \\
\text { Asia group countries have } \\
\text { recommended steps for further } \\
\text { refining their Code development } \\
\text { process based on the experience of } \\
\text { Pacific countries. }\end{array}$ \\
\hline
\end{tabular}




\section{Strategy 2}

\section{Develop Awareness and Support for the Code at the Regional and National Policy- Making Levels by Stakeholders}

A fundamental component of having the Code implemented is to ensure the policy makers are fully aware of the Code, what it is designed to do and how it can be implemented.

\begin{tabular}{|c|c|c|}
\hline Objectives & Actions & Outcomes \\
\hline $\begin{array}{l}\text { To improve awareness } \\
\text { throughout the APFC } \\
\text { member countries at the } \\
\text { policy level of the } \\
\text { existence and broad } \\
\text { content of the Code of } \\
\text { Practice for Forest } \\
\text { Harvesting in Asia-Pacific } \\
\text { and its purpose. }\end{array}$ & 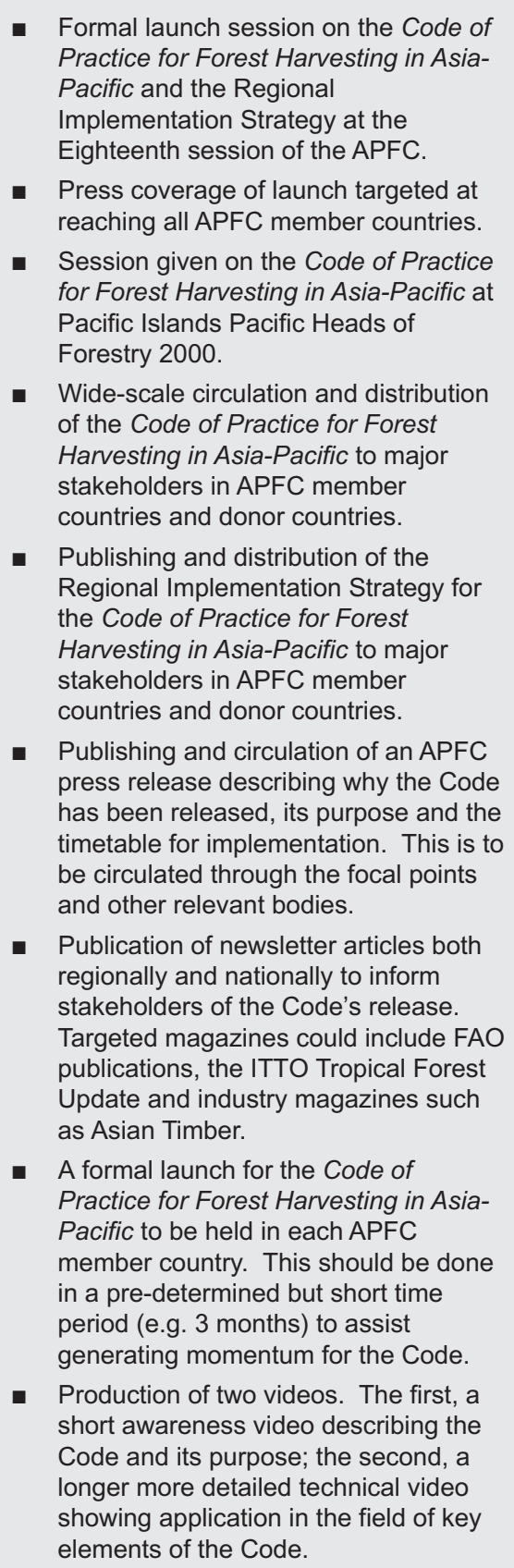 & $\begin{array}{l}\text { Greater awareness of the existence of } \\
\text { the Code of Practice for Forest } \\
\text { Harvesting in Asia-Pacific and the } \\
\text { implementation strategy at the policy } \\
\text { level within the Forestry Department. } \\
\text { - Formal documentation detailing the } \\
\text { APFC's planned implementation } \\
\text { strategy. } \\
\text { Copies of the Code of Practice for } \\
\text { Forest Harvesting in Asia-Pacific and } \\
\text { the Regional Implementation Strategy } \\
\text { sent to most stakeholder groups } \\
\text { spreading awareness and providing } \\
\text { individuals and organisations with the } \\
\text { required information to progress } \\
\text { implementation. } \\
\text { Greater awareness at all levels of the } \\
\text { existence of the Code of Practice for } \\
\text { Forest Harvesting in Asia-Pacific and } \\
\text { the implementation strategy. } \\
\text { A formal launch and acceptance of the } \\
\text { Code of Practice for Forest Harvesting } \\
\text { in Asia-Pacific by each APFC member } \\
\text { country. } \\
\text { Development of awareness and } \\
\text { training aids. }\end{array}$ \\
\hline
\end{tabular}




\begin{tabular}{|c|c|c|}
\hline Objectives & Actions & Outcomes \\
\hline $\begin{array}{l}\text { To provide a dedicated } \\
\text { person tasked to carry out } \\
\text { code awareness, training } \\
\text { and implementation } \\
\text { activities on a regional } \\
\text { basis and in a support role } \\
\text { as requested at the } \\
\text { national level. }\end{array}$ & $\begin{array}{l}\text { APFC to seek funding for a Code } \\
\text { implementation officer for a period of } \\
\text { not less than } 2 \text { years. } \\
\text { Job description for the Code } \\
\text { implementation officer to be developed } \\
\text { by the ad hoc Working Group based on } \\
\text { the requirements of this implementation } \\
\text { strategy and other perceived needs. } \\
\text { - A suitable applicant to be selected. }\end{array}$ & $\begin{array}{l}\text { A specialised and dedicated Code } \\
\text { implementation officer capable of } \\
\text { actively progressing the } \\
\text { implementation strategy across the } \\
\text { region. }\end{array}$ \\
\hline $\begin{array}{l}\text { To encourage adoption of } \\
\text { the code in order to } \\
\text { realise its benefits. }\end{array}$ & $\begin{array}{l}\text { Obtain funding through APFC donor } \\
\text { countries and other sources to provide } \\
\text { a general fund for Code } \\
\text { implementation activities. These funds } \\
\text { should be allocated at the discretion of } \\
\text { the ad hoc Working Group but are } \\
\text { likely to assist the Code } \\
\text { implementation officer to conduct } \\
\text { awareness and training activities and } \\
\text { provide funds that can be channelled to } \\
\text { national steering committees to assist } \\
\text { their implementation activities. } \\
\text { Pursue support from donor countries to } \\
\text { sponsor a minimum of } 1 \text { participant } \\
\text { from the 'policy maker' group of each of } \\
\text { the relevant Forestry Department, } \\
\text { NGO, industry and community bodies } \\
\text { of each APFC country to attend the } \\
\text { Train the Trainer workshop series. As } \\
\text { Forest Departments are likely to have } \\
\text { the lead role, a minimum of } 2 \\
\text { participants is appropriate to cover } \\
\text { contingencies. }\end{array}$ & $\begin{array}{l}\text { A minimum of } 1 \text { key person within } \\
\text { each stakeholder group and } 2 \\
\text { persons from the Forest Department } \\
\text { of each APFC member country } \\
\text { understands the process that is under } \\
\text { way and has the skills to pass the } \\
\text { information on to others. }\end{array}$ \\
\hline $\begin{array}{l}\text { To create an environment } \\
\text { where there will be } \\
\text { stakeholder acceptance } \\
\text { of the Code }\end{array}$ & $\begin{array}{l}\text { Conduct a series of sub-regional Train } \\
\text { the Trainer workshops with key Forest } \\
\text { Department, industry, NGO and } \\
\text { landowner representatives from APFC } \\
\text { member countries. } \\
\text { Provide follow-up support for } \\
\text { participants in the Train the Trainer } \\
\text { program to run in country training } \\
\text { programs. }\end{array}$ & $\begin{array}{l}\text { Availability of a trained core of } \\
\text { individuals capable of preparing and } \\
\text { commencing the process of } \\
\text { implementing the Code of Practice for } \\
\text { Forest Harvesting in Asia-Pacific } \\
\text { within their respective organisations. }\end{array}$ \\
\hline
\end{tabular}




\section{Strategy 3}

\section{Development of a Forest Sector That Is Educated and Trained in Code Implementation}

If the Code is to be implemented, it is imperative that all staff in the forest sector are motivated and have the necessary education and training. Staff from all stakeholder groups require an understanding of the science behind the Code as well as the content and what it means when put into practice. With this knowledge will come the understanding of the reasons for a Code, resulting in a desire and pride in achieving implementation.

\begin{tabular}{|c|c|c|}
\hline Objectives & Actions & Outcomes \\
\hline $\begin{array}{l}\text { To improve the } \\
\text { understanding of forest } \\
\text { sector personnel in } \\
\text { implementation of } \\
\text { sustainable forest } \\
\text { management practices. }\end{array}$ & $\begin{array}{l}\text { Conduct a 'needs analysis' survey to } \\
\text { determine training and awareness } \\
\text { requirements within APFC countries } \\
\text { and priorities for support activities } \\
\text { based on current harvesting, } \\
\text { supervision and legislative systems. } \\
\text { This should be regionally co- } \\
\text { ordinated by FAO and/or the Code } \\
\text { implementation officer through the } \\
\text { focal points of each APFC country to } \\
\text { determine regional priorities. } \\
\text { As a component of awareness and } \\
\text { training programs on the Code of } \\
\text { Practice for Forest Harvesting in } \\
\text { Asia-Pacific include the concept of } \\
\text { sustainable forest management in the } \\
\text { program of all training workshops. } \\
\text { A series of field tours to a suitable } \\
\text { demonstration forest and harvesting } \\
\text { area to be held for selected Forestry } \\
\text { Department, Industry, landowner and } \\
\text { NGO personnel. Initially this will be } \\
\text { on a sub-regional basis but will later } \\
\text { be on a country basis. It is } \\
\text { suggested that the Code } \\
\text { implementation officer be responsible } \\
\text { for organisation of these tours. }\end{array}$ & $\begin{array}{l}\text { - Support, training and awareness } \\
\text { requirements of member countries } \\
\text { identified and prioritised within } \\
\text { member countries. } \\
\text { - Allocation of resources based on } \\
\text { identified priorities to achieve } \\
\text { successful implementation of the } \\
\text { Code. } \\
\text { - Trainees with a better } \\
\text { understanding of the full } \\
\text { requirements for achieving } \\
\text { sustainable forest management. } \\
\text { Participants develop an } \\
\text { understanding of what a good } \\
\text { forest harvesting operation looks } \\
\text { like and aim at producing the } \\
\text { same type of operational standard } \\
\text { in their own countries. }\end{array}$ \\
\hline $\begin{array}{l}\text { To improve the quality } \\
\text { of forest harvesting } \\
\text { operations through } \\
\text { Code implementation. } \\
\text { To create a body of } \\
\text { trained supervisory } \\
\text { and industry staff. }\end{array}$ & $\begin{array}{l}\text { Conduct a series of regional Train the } \\
\text { Trainer workshops with personnel } \\
\text { from key stakeholder groups within } \\
\text { APFC member countries. Workshop } \\
\text { coordination and curriculum should } \\
\text { be the responsibility of the Code } \\
\text { implementation officer based on the } \\
\text { existing pilot workshop. } \\
\text { Staff from the regional Train the } \\
\text { Trainer workshops to conduct in- } \\
\text { country awareness and training } \\
\text { programs based on their own national } \\
\text { codes and where appropriate on the } \\
\text { Code of Practice for Forest } \\
\text { Harvesting in Asia-Pacific. }\end{array}$ & $\begin{array}{l}\text { An increased number of key } \\
\text { personnel who share the vision for } \\
\text { implementation of the Code and } \\
\text { have the required skills to be a part } \\
\text { of implementing that vision. } \\
\text { - Greater awareness of the regional } \\
\text { and national codes and the } \\
\text { requirements for implementation. } \\
\text { - Stakeholders aware of and } \\
\text { beginning to prepare for Code } \\
\text { implementation. } \\
\text { - Funding to support the national } \\
\text { implementation programs. } \\
\text { - A pool of trained staff to conduct } \\
\text { the implementation program. }\end{array}$ \\
\hline
\end{tabular}




\begin{tabular}{|l|l|l|}
\hline Objectives & Actions & Outcomes \\
\hline & $\begin{array}{l}\text { Funds to be pursued on regional and } \\
\text { national bases to run in country } \\
\text { awareness and Train the Trainer } \\
\text { programs. }\end{array}$ & $\begin{array}{l}\text { Village or community-based } \\
\text { operations complying with the Code. } \\
\text { Supervisors and operators with a } \\
\text { clear understanding of the } \\
\text { requirements that they must meet to } \\
\text { achieve conformance with the } \\
\text { national code. }\end{array}$ \\
& $\begin{array}{l}\text { Staff from the regional Train the } \\
\text { Trainer program to run supported, in- } \\
\text { country, Train the Trainer workshops } \\
\text { based on the national code, or where } \\
\text { appropriate the Asia-Pacific Code. } \\
\text { Initially it is envisaged that back-up } \\
\text { support and mentoring be provided by } \\
\text { the lead trainers at the regional Train } \\
\text { the Trainer program. } \\
\text { NGO staff who have attended a } \\
\text { regional Train the Trainer program to } \\
\text { coordinate Code training at the village } \\
\text { or community level with a focus on the } \\
\text { walkabout sawmill style of operation. } \\
\text { Trainers to conduct operation level } \\
\text { based workshops on required } \\
\text { practices. May utilise demonstration } \\
\text { forest where available. }\end{array}$ & \\
& \\
&
\end{tabular}




\section{Strategy 4}

\section{Encourage the Development and Implementation of National Codes Based on the Asia-Pacific Code}

While the Code of Practice for Forest Harvesting in Asia-Pacific is a comprehensive document for the forests in the region, most countries will wish to develop national codes of practice which are tailormade to their particular situations. The technical content in the Code will form the basis of the national codes with variations in terminology and techniques made to suit the particular locations.

\begin{tabular}{|c|c|c|}
\hline Objectives & Actions & Outcomes \\
\hline $\begin{array}{l}\text { Create a broad } \\
\text { awareness of the } \\
\text { Code and } \\
\text { implementation } \\
\text { strategy at a national } \\
\text { level. }\end{array}$ & $\begin{array}{l}\text { Progression of the actions detailed in } \\
\text { Strategy } 2 \text {. } \\
\text { Repeat country visits by the appointed } \\
\text { Code implementation officer in an } \\
\text { awareness role. These will act to } \\
\text { educate and create awareness of the } \\
\text { processes occurring at the regional } \\
\text { level and encourage similar actions at } \\
\text { a national level. }\end{array}$ & $\begin{array}{l}\text { Key stakeholder bodies aware and } \\
\text { ready to participate in Code } \\
\text { implementation and then in } \\
\text { development and implementation of a } \\
\text { national code. } \\
\text { - Increased positive and proactive } \\
\text { environment within which to achieve } \\
\text { change. }\end{array}$ \\
\hline $\begin{array}{l}\text { To generate country- } \\
\text { level acceptance of the } \\
\text { need for national codes. }\end{array}$ & $\begin{array}{l}\text { Development of a national stakeholder } \\
\text { body including Department of Forestry, } \\
\text { other relevant governmental agencies, } \\
\text { industry organisations, NGOs and } \\
\text { (where appropriate) landowner } \\
\text { representatives to act as a steering } \\
\text { committee for the process of Code } \\
\text { development and implementation. The } \\
\text { Code implementation officer may be a } \\
\text { part of this committee to assist in } \\
\text { facilitating the process and provide } \\
\text { indications as to successful practices } \\
\text { used to achieve implementation in } \\
\text { other countries. } \\
\text { Review by the stakeholder body of the } \\
\text { Asia-Pacific Code and its role in } \\
\text { further developing the country's forest } \\
\text { management practices. }\end{array}$ & $\begin{array}{l}\text { Increased country-level acceptance } \\
\text { of the Code. } \\
\text { - Better understanding among } \\
\text { stakeholders of the requirements of a } \\
\text { code of practice. }\end{array}$ \\
\hline $\begin{array}{l}\text { Improvement of the } \\
\text { current guidelines for } \\
\text { forest management } \\
\text { through the } \\
\text { development of a code. }\end{array}$ & $\begin{array}{l}\text { Restructuring of the Asia-Pacific Code } \\
\text { by the Forestry Department to produce } \\
\text { a draft national code of practice for } \\
\text { presentation to the national } \\
\text { stakeholder body. } \\
\text { Use of the Asia-Pacific Code by } \\
\text { Pacific countries to refine their existing } \\
\text { codes. } \\
\text { Trialing of the draft code on a small- } \\
\text { scale basis with an appropriate } \\
\text { industry group. } \\
\text { Changes made to the draft national } \\
\text { code based on the industry trial and } \\
\text { feedback from stakeholder groups. } \\
\text { Acceptance of the draft code by the } \\
\text { stakeholder steering committee. } \\
\text { Release of the national code of } \\
\text { practice for forest harvesting. }\end{array}$ & $\begin{array}{l}\text { - Generation of a draft national code } \\
\text { which is appropriate and accepted by } \\
\text { the country. } \\
\text { - Performance testing of the code } \\
\text { allowing refinements as required. } \\
\text { - Development of the first } \\
\text { demonstration forest area. } \\
\text { A national code of practice for forest } \\
\text { harvesting for each APFC country } \\
\text { based on the Code of Practice for } \\
\text { Forest Harvesting in Asia-Pacific. }\end{array}$ \\
\hline
\end{tabular}




\begin{tabular}{|c|c|c|}
\hline Objectives & Actions & Outcomes \\
\hline $\begin{array}{l}\text { To generate a strategy } \\
\text { whereby a national code } \\
\text { can be implemented. }\end{array}$ & $\begin{array}{l}\text { Development of a national } \\
\text { framework, which includes all } \\
\text { stakeholder groups for } \\
\text { implementation of the national or } \\
\text { where appropriate regional code. } \\
\text { Coordination of training institutions } \\
\text { by the steering committee to make } \\
\text { appropriate changes to course } \\
\text { curriculum to include training on the } \\
\text { Code and at a later date } \\
\text { competency-based courses. } \\
\text { Calls through APFC and other } \\
\text { agencies for donor support to assist } \\
\text { in funding the implementation } \\
\text { strategy. } \\
\text { Development of a training program } \\
\text { structure for implementation of the } \\
\text { Code. This should utilise the } \\
\text { trainees from the regional Trainer } \\
\text { training programs as teaching staff } \\
\text { and tie in with the actions detailed in } \\
\text { Strategy } 3 \text {. }\end{array}$ & $\begin{array}{l}\text { - A framework for implementation of } \\
\text { the national code. } \\
\text { - Funding assistance to support the } \\
\text { implementation program. } \\
\text { - A training program to commence } \\
\text { implementation. }\end{array}$ \\
\hline
\end{tabular}




\section{Strategy 5}

\section{Establishment of Demonstration and Training Forests}

If seeing is believing, then learning by doing will provide the basis for improved knowledge uptake. The purpose of the demonstration forests is twofold. First it enables trainees to actually conduct planning, pre-harvest works, carry out the operation and complete a rehabilitation program in an educational environment. Secondly it provides a visual example of a 'good' harvesting operation for others visiting the site. This becomes a very powerful teaching and demonstration tool when undertaken in a forest that is similar to that experienced in a normal work environment.

\begin{tabular}{|c|c|c|}
\hline Objectives & Actions & Outcomes \\
\hline $\begin{array}{l}\text { To establish a series of } \\
\text { appropriately located } \\
\text { demonstration sites in } \\
\text { all significant forest } \\
\text { types within each sub- } \\
\text { region for ease of } \\
\text { accessibility. }\end{array}$ & $\begin{array}{l}\text { - Selection of appropriate easily } \\
\text { accessed sites within each forest type } \\
\text { of each sub-region for establishment of } \\
\text { demonstration forests. } \\
\text { - Planning for and harvesting of sites in } \\
\text { compliance with the Code and other } \\
\text { appropriate guidelines using a willing } \\
\text { industry organisation or training } \\
\text { institution to harvest the area. } \\
\text { - Development of community or village- } \\
\text { based demonstration forests by NGO } \\
\text { community-based projects. } \\
\text { - Post harvest rehabilitation in } \\
\text { conformance with Code. } \\
\text { Monitoring and auditing of the site to } \\
\text { ensure operation conducted in } \\
\text { compliance with the Code and to } \\
\text { provide a record of activity over time. } \\
\text { Continue demonstration operations in } \\
\text { the area. }\end{array}$ & $\begin{array}{l}\text { Provision of appropriate areas within } \\
\text { each sub-region and forest type for } \\
\text { establishment of demonstration } \\
\text { forests. } \\
\text { - Development of a select trained team } \\
\text { of operators and supervisors with } \\
\text { experience in harvesting according to } \\
\text { the Code and the ability to train } \\
\text { others. } \\
\text { Demonstration forest sites } \\
\text { established for the education of } \\
\text { interested parties, managers, } \\
\text { operators, landowners and trainees. } \\
\text { - A variety of sites which show the } \\
\text { results of Code application across a } \\
\text { series of time periods. }\end{array}$ \\
\hline $\begin{array}{l}\text { To improve the } \\
\text { understanding of } \\
\text { managers and operators } \\
\text { about what can be } \\
\text { achieved through } \\
\text { compliance with the } \\
\text { code by involving them } \\
\text { in demonstration forest } \\
\text { development. }\end{array}$ & $\begin{array}{l}\text { - Selection of key industry and forestry } \\
\text { stakeholders to take part in } \\
\text { development of the demonstration } \\
\text { forest. } \\
\text { - Awareness field days (after completion } \\
\text { of operations) with relevant key } \\
\text { stakeholders. } \\
\text { Development of a training curriculum } \\
\text { by the Code implementation officer to } \\
\text { take industry and forestry personnel } \\
\text { through the process used to implement } \\
\text { the Code in the demonstration forest. }\end{array}$ & $\begin{array}{l}\text { - A small highly trained team with } \\
\text { experience in harvesting according to } \\
\text { the Code and the ability to train others. } \\
\text { - A larger group of experienced trainers. } \\
\text { Awareness within the industry, forestry } \\
\text { department and other stakeholder } \\
\text { organisations of the required actions } \\
\text { and results of harvesting according to } \\
\text { the Code. } \\
\text { Accredited operators who have shown } \\
\text { an ability to plan and implement an } \\
\text { operation to the Code required level. }\end{array}$ \\
\hline $\begin{array}{l}\text { Support testing of } \\
\text { practices that may be } \\
\text { new to a country. }\end{array}$ & $\begin{array}{l}\text { New practices to be implemented } \\
\text { when developing demonstration } \\
\text { forest. }\end{array}$ & $\begin{array}{l}\text { Understanding of new practices and } \\
\text { the results of their usage among } \\
\text { key stakeholders. }\end{array}$ \\
\hline $\begin{array}{l}\text { Provide a site for long- } \\
\text { term research into better } \\
\text { harvest practices and the } \\
\text { future generation of } \\
\text { Silvicultural } \\
\text { Prescriptions. }\end{array}$ & $\begin{array}{l}\text { Relevant research organisations to } \\
\text { establish long-term trials on } \\
\text { demonstration forest sites. }\end{array}$ & $\begin{array}{l}\text { Better long-term data on best } \\
\text { management processes } \\
\text { Feedback loop for provision of } \\
\text { information and data into the future } \\
\text { and the ongoing refinement of } \\
\text { practices. }\end{array}$ \\
\hline
\end{tabular}




\section{Strategy 6}

\section{Implementation of Monitoring and Auditing Systems}

Monitoring of Code implementation at the ground level is of key importance in determining the success or failure of the Code implementation program. It is essential that an initial audit be carried out to provide a baseline for comparison in the future (this can be on a regional, sub-regional or national level). It is then expected that it will be up to a year before the effects of the training programs will begin to be observed at the operational level. Follow-up monitoring will assess the level of compliance being achieved. This level can then be progressively raised over time as the Code is fully implemented.

\begin{tabular}{|c|c|c|}
\hline Objectives & Actions & Outcomes \\
\hline $\begin{array}{l}\text { To increase the } \\
\text { understanding of how to } \\
\text { carry out planning for and } \\
\text { implementation of } \\
\text { operational monitoring } \\
\text { and auditing programs. }\end{array}$ & $\begin{array}{l}\text { Incorporate monitoring and auditing } \\
\text { as an important component of all sub- } \\
\text { regional and national workshops, } \\
\text { including, where possible, practical } \\
\text { field activities using these systems. }\end{array}$ & $\begin{array}{l}\text { A trained group of people with the } \\
\text { knowledge to teach others and to } \\
\text { establish and run a monitoring and } \\
\text { auditing program for forest } \\
\text { harvesting operations. }\end{array}$ \\
\hline $\begin{array}{l}\text { To improve the quality of } \\
\text { forest harvesting } \\
\text { operations on a national } \\
\text { level through effective } \\
\text { monitoring and auditing } \\
\text { practices. }\end{array}$ & $\begin{array}{l}\text { - A national baseline audit to be } \\
\text { carried out to determine current } \\
\text { operating standards. } \\
\text { - New national minimum compliance } \\
\text { levels to be determined and a date } \\
\text { set for achievement of new levels. } \\
\text { - Development or reinforcement of an } \\
\text { effective hierarchical structure within } \\
\text { forest departments to allow } \\
\text { monitoring and auditing to occur in } \\
\text { an efficient and effective manner. } \\
\text { - Monitoring program to commence } \\
\text { with on ground support from key } \\
\text { Forestry Department staff. } \\
\text { - First compliance audit to assess } \\
\text { operational standards against the } \\
\text { specified predetermined standards. } \\
\text { - New national compliance levels set. } \\
\text { - Ongoing monitoring and auditing } \\
\text { with the annual generation of } \\
\text { SMART (specific, measurable, } \\
\text { attainable, relevant and time bound) } \\
\text { objectives to guide future activity. }\end{array}$ & $\begin{array}{l}\text { Definition of standards currently } \\
\text { being achieved nationally by } \\
\text { industry operations. } \\
\text { A set of revised standards } \\
\text { outlining the level by which } \\
\text { operations are expected to } \\
\text { improve in a given time frame. } \\
\text { Trained and effective supervisors } \\
\text { who feel well supported and are } \\
\text { competent at their tasks. } \\
\text { Determination of the level of } \\
\text { compliance achieved and the } \\
\text { effectiveness of the Code } \\
\text { implementation program to date. } \\
\text { A new and realistic set of national } \\
\text { benchmarks for the next } \\
\text { compliance audit. } \\
\text { An ongoing monitoring and } \\
\text { auditing program. }\end{array}$ \\
\hline
\end{tabular}




\section{Strategy 7}

\section{Collation of Past and Present Research Results Allowing Development of Appropriate Research Activities and Directions in Support of Sustainable Forest Management}

A great deal of research has been undertaken related to improved forest management and in particular timber harvesting. Prior to undertaking further research, an inventory needs to be carried out and a needs analysis completed for the clients to ascertain where future research should be aimed.

\begin{tabular}{|c|c|c|}
\hline Objectives & Actions & Outcomes \\
\hline $\begin{array}{l}\text { To improve knowledge of } \\
\text { the cost and benefits of } \\
\text { implementing the Code of } \\
\text { Practice for Forest } \\
\text { Harvesting in Asia-Pacific } \\
\text { and other principles and } \\
\text { practices for forest } \\
\text { harvesting, specifically RIL } \\
\text { Guidelines. }\end{array}$ & $\begin{array}{l}\text { Determination of past and existing } \\
\text { research projects and identification of } \\
\text { their suitability to cover existing } \\
\text { information requirements for Code } \\
\text { implementation. } \\
\text { - Determination of gaps in current } \\
\text { research and development of a } \\
\text { program for future research } \\
\text { requirements. } \\
\text { Application through APFC and other } \\
\text { bilateral and donor organisations for } \\
\text { funding on a project-specific basis. } \\
\text { The existing APFC ad hoc Working } \\
\text { Group to co-ordinate funding, } \\
\text { determine project structures and } \\
\text { timing and ensure that results are } \\
\text { made available to all stakeholders. }\end{array}$ & $\begin{array}{l}\text { A wider availability of information } \\
\text { and support for the introduction of } \\
\text { the Code of Practice for Forest } \\
\text { Harvesting in Asia-Pacific and other } \\
\text { principles and practices for forest } \\
\text { harvesting including RIL Guidelines. } \\
\text { Industry and other stakeholder } \\
\text { groups better informed on the cost } \\
\text { and benefits associated with } \\
\text { implementation of the Code of } \\
\text { Practice for Forest Harvesting in } \\
\text { Asia-Pacific and other principles and } \\
\text { practices for forest harvesting. }\end{array}$ \\
\hline $\begin{array}{l}\text { To improve the knowledge } \\
\text { of the silvicultural } \\
\text { requirements of } \\
\text { production forestry to } \\
\text { enhance sustainability. }\end{array}$ & $\begin{array}{l}\text { Within the framework of other bilateral } \\
\text { research projects, establish a specific } \\
\text { set of projects focused on } \\
\text { development of forest type specific } \\
\text { silvicultural prescriptions. This may } \\
\text { be done within the demonstration } \\
\text { forest program. }\end{array}$ & $\begin{array}{l}\text { Improved information to support the } \\
\text { introduction of silvicultural } \\
\text { prescriptions in line with the forest's } \\
\text { biological capacity. } \\
\text { - Clarification of appropriate silvicultural } \\
\text { activities and their associated costs. }\end{array}$ \\
\hline $\begin{array}{l}\text { To improve the } \\
\text { knowledge of the impacts } \\
\text { of different policies and } \\
\text { societal trends on } \\
\text { secondary production } \\
\text { forests to enhance their } \\
\text { sustainability. }\end{array}$ & $\begin{array}{l}\text { Within the framework of other bilateral } \\
\text { research projects, establish a specific } \\
\text { set of projects focused on determining } \\
\text { impacts on various secondary } \\
\text { production forest types. }\end{array}$ & $\begin{array}{l}\text { Clarification of appropriate } \\
\text { management regimes and their } \\
\text { associated costs. }\end{array}$ \\
\hline
\end{tabular}




\section{Strategy 8}

\section{Further Development and Implementation of Sustainable Forest Management Practices in Asia-Pacific}

The Code of Practice for Forest Harvesting in Asia-Pacific is a valuable document in promoting SFM. However, there are many other aspects involved in the endeavour to achieve the goals of SFM in the forests of Asia-Pacific. This strategy outlines some of those objectives that promote SFM in the region.

\begin{tabular}{|c|c|c|}
\hline Objectives & Actions & Outcomes \\
\hline $\begin{array}{l}\text { To assist policy makers at } \\
\text { the regional level to } \\
\text { develop a regional vision } \\
\text { and strategy for } \\
\text { sustainable forest } \\
\text { management. }\end{array}$ & $\begin{array}{l}\text { The ad hoc Working Group to co- } \\
\text { ordinate development of a long-term } \\
\text { strategy for achieving sustainable } \\
\text { management guidelines other than the } \\
\text { Code. This should include a timetable } \\
\text { for development of Reduced Impact } \\
\text { Logging Guidelines and a commitment } \\
\text { to forest type-based Silvicultural } \\
\text { Prescriptions by member countries on a } \\
\text { sub-regional basis. } \\
\text { - Continued support from the APFC for } \\
\text { other SFM initiatives throughout the } \\
\text { region such as RILNET and the recently } \\
\text { submitted joint proposal to ITTO through } \\
\text { APFC, Indonesia and Australia. }\end{array}$ & $\begin{array}{l}\text { A timetable for the development and } \\
\text { implementation of support guidelines } \\
\text { that complement the Code of } \\
\text { Practice for Forest Harvesting in } \\
\text { Asia-Pacific. } \\
\text { Long-term regional plans by the } \\
\text { APFC member countries to institute } \\
\text { sustainable forest management. } \\
\text { Coordination of all agencies to work } \\
\text { towards the same common goal. }\end{array}$ \\
\hline $\begin{array}{l}\text { To assist policy makers } \\
\text { at the national level to } \\
\text { develop a national vision } \\
\text { and strategy for } \\
\text { sustainable forest } \\
\text { management. }\end{array}$ & $\begin{array}{l}\text { Through the APFC focal points, co- } \\
\text { ordinate the development of clear policy } \\
\text { at departmental level aimed at instituting } \\
\text { RIL Guidelines and Silvicultural } \\
\text { Prescriptions based on the APFC's } \\
\text { guidelines and in-country research. } \\
\text { This policy should indicate that the } \\
\text { national code is only an element leading } \\
\text { to sustainable forest management. }\end{array}$ & $\begin{array}{l}\text { A coordinated long-term national plan } \\
\text { by APFC member countries to institute } \\
\text { sustainable forest management } \\
\text { practices. }\end{array}$ \\
\hline $\begin{array}{l}\text { To develop regional RIL } \\
\text { Guidelines designed to } \\
\text { complement the Code of } \\
\text { Practice for Forest } \\
\text { Harvesting in Asia- } \\
\text { Pacific. }\end{array}$ & $\begin{array}{l}\text { The ad hoc Working Group of the } \\
\text { APFC to seek donor support for } \\
\text { development of RIL Guidelines to } \\
\text { support the Code of Practice for Forest } \\
\text { Harvesting in Asia-Pacific. } \\
\text { A tender to be let for development of } \\
\text { the regional RIL Guidelines and } \\
\text { presentation of a draft to the focal } \\
\text { points of the member countries for } \\
\text { comment before acceptance by the ad } \\
\text { hoc Working Group. }\end{array}$ & $\begin{array}{l}\text { - Regional RIL Guidelines applicable to } \\
\text { all APFC member countries and } \\
\text { supporting the Code of Practice for } \\
\text { Forest Harvesting in Asia-Pacific. }\end{array}$ \\
\hline $\begin{array}{l}\text { To develop forest type- } \\
\text { specific sub-regional } \\
\text { Silvicultural } \\
\text { Prescriptions. }\end{array}$ & $\begin{array}{l}\text { APFC Working Group to co-ordinate an } \\
\text { analysis determining the number and } \\
\text { approximate location of production } \\
\text { management forest types in the Asia- } \\
\text { Pacific. } \\
\text { APFC Working Group to be responsible } \\
\text { for coordination of available information } \\
\text { and development of sub-regional } \\
\text { Silvicultural Prescriptions. } \\
\text { APFC Working Group to set a timeline } \\
\text { for implementation of Silvicultural } \\
\text { Prescriptions. }\end{array}$ & $\begin{array}{l}\text { Broad forest type analysis detailing } \\
\text { location and forest type across the } \\
\text { APFC member countries. } \\
\text { - Collation and sharing of data allowing } \\
\text { development of effective Silvicultural } \\
\text { Prescriptions. } \\
\text { - Implementation and revision of } \\
\text { Silvicultural Prescriptions. }\end{array}$ \\
\hline
\end{tabular}




\section{Responsibilities and Timing}

The implementation of the Regional Strategy will involve appropriate actions by all stakeholders. These include:

- Government

- Concession holders

- Landowners

- Relevant NGOs

- International Organisations (i.e. forestry, forest industry, forest research and forest conservation)

- Bilateral and multilateral donors

The governments of the member countries of APFC will have a major role to play in such actions, particularly through their respective forest departments. However, the private sector will have the primary role for implementation and development of implementation systems. A summary of the priorities and those responsible for the specific actions is presented in Table 5.1. A suggested time frame is given under the headings immediate (within 2 years), mid-term ( $2-5$ years) and long-term (5-10 years).

To achieve implementation of the Code of Practice for Forest Harvesting in Asia-Pacific actions need to be undertaken at the regional, national and local levels. Table 5.1 deals mainly with actions at the regional and national levels. Finer detail at the local level will follow once the appropriate national frameworks and directions are set.

Table 5.1. Responsibilities and Timing for the Implementation of the Regional Strategy

\begin{tabular}{|c|c|c|c|}
\hline Institution & Immediate (Within 2 years) & Mid-Term (2-5 years) & Long-Term (5-10 years) \\
\hline APFC & $\begin{array}{l}\text { - Release a statement supporting } \\
\text { the development of national } \\
\text { codes at the Eighteenth Session } \\
\text { of the APFC. } \\
\text { - Formally launch the Code of } \\
\text { Practice for Forest Harvesting in } \\
\text { the Asia-Pacific and the } \\
\text { Regional Implementation } \\
\text { Strategy at the Eighteenth } \\
\text { Session of the APFC. } \\
\text { - Ad hoc Working Group to } \\
\text { coordinate distribution of the } \\
\text { Code and Regional Strategy } \\
\text { throughout all member countries } \\
\text { and to as many stakeholder } \\
\text { bodies as possible. } \\
\text { - Funding to be sought for a Code } \\
\text { implementation officer. } \\
\text { - Ad hoc Working Group to seek } \\
\text { and employ a suitably qualified } \\
\text { person as the Code } \\
\text { implementation officer. } \\
\text { - The ad hoc Working Group and/ } \\
\text { or the Code implementation } \\
\text { officer to facilitate the formal } \\
\text { launch of the Code in each } \\
\text { member country. }\end{array}$ & $\begin{array}{l}\text { - Code implementation officer } \\
\text { to set awareness and } \\
\text { training priorities under the } \\
\text { jurisdiction of the ad hoc } \\
\text { Working Group. } \\
\text { - APFC to seek and direct } \\
\text { support funds for national } \\
\text { code implementation. } \\
\text { - Ad hoc Working Group to } \\
\text { provide and/or direct funds } \\
\text { for research requirements as } \\
\text { previously determined. } \\
\text { - APFC body to coordinate the } \\
\text { development of regional } \\
\text { reduced impact harvesting } \\
\text { guidelines. }\end{array}$ & $\begin{array}{l}\text { - Continue to direct policy and } \\
\text { research as required. }\end{array}$ \\
\hline
\end{tabular}


Table 5.1. (Continued) Responsibilities and Timing for the Implementation of the Regional Strategy

\begin{tabular}{|c|c|c|c|}
\hline Institution & Immediate (Within 2 years) & Mid-Term (2-5 years) & Long-Term (5-10 years) \\
\hline & $\begin{array}{l}\text { Obtain funds to be allocated at } \\
\text { the discretion of the ad hoc } \\
\text { Working Group to support both } \\
\text { regional and national code } \\
\text { implementation activities. } \\
\text { - Ad hoc Working Group or } \\
\text { another selected body to } \\
\text { commence examining research } \\
\text { activities to date. } \\
\text { - Ensure that any implemented } \\
\text { training, awareness or research } \\
\text { programs operate within the } \\
\text { frameworks already created by } \\
\text { other regional and bilateral } \\
\text { programs. }\end{array}$ & & \\
\hline $\begin{array}{l}\text { National } \\
\text { Forest } \\
\text { Ministries }\end{array}$ & $\begin{array}{l}\text { - Support the release of the Code } \\
\text { of Practice for Forest Harvesting } \\
\text { in the Asia-Pacific and the } \\
\text { Regional Strategy for Develop- } \\
\text { ment and Implementation of the } \\
\text { Code of Practice for Forest } \\
\text { Harvesting in Asia-Pacific. } \\
\text { - Evaluate and refine national } \\
\text { policy and/or legislation to } \\
\text { formally adopt the Code. } \\
\text { - Coordinate development of } \\
\text { individual country-based codes } \\
\text { and where applicable forest } \\
\text { type-based codes on a sub- } \\
\text { regional level. } \\
\text { - Develop an implementation } \\
\text { schedule with defined criteria } \\
\text { and timings for enforcement. } \\
\text { - Commence planning and } \\
\text { development of demonstration } \\
\text { forests. } \\
\text { - Attend regional Train the Trainer } \\
\text { programs. } \\
\text { - Develop own in-country trainer } \\
\text { training program. } \\
\text { - Develop schedule and } \\
\text { commence in-country } \\
\text { implementation training } \\
\text { programs. } \\
\text { - Ensure an effective } \\
\text { departmental structure exists to } \\
\text { allow monitoring and auditing to } \\
\text { occur. } \\
\text { audit to allow setting of initial } \\
\text { program target levels. } \\
\text { Develop a system of } \\
\text { enforcement for companies who } \\
\text { fail to comply. }\end{array}$ & $\begin{array}{l}\text { - Follow implementation } \\
\text { schedule with regular review } \\
\text { of progress and adjustment } \\
\text { as required. } \\
\text { - Commence monitoring and } \\
\text { evaluation program with } \\
\text { comparison against baseline } \\
\text { levels. } \\
\text { - Implement demonstration } \\
\text { forests. } \\
\text { - Coordinate testing of } \\
\text { Reduced Impact Logging } \\
\text { procedures. } \\
\text { - Commence development of } \\
\text { an operator accreditation } \\
\text { program. } \\
\text { - Target for full implementation } \\
\text { of the Code of Practice for } \\
\text { Forest Harvesting in the Asia- } \\
\text { Pacific or the national code } \\
\text { by the end of this period. }\end{array}$ & $\begin{array}{l}\text { Continue monitoring and } \\
\text { auditing program with } \\
\text { provision of regular } \\
\text { feedback to companies at } \\
\text { both supervisor and } \\
\text { operator levels. } \\
\text { - Removal of operations that } \\
\text { have continually failed to } \\
\text { comply with the } \\
\text { predetermined standards to } \\
\text { be achieved in Code } \\
\text { implementation. } \\
\text { - Evaluation of Silvicultural } \\
\text { Prescriptions as developed } \\
\text { through the research } \\
\text { program. } \\
\text { - Ongoing monitoring and } \\
\text { reporting on permanent } \\
\text { sample plots. } \\
\text { - Raise the achievement } \\
\text { level required to monitor } \\
\text { programs. } \\
\text { - Implement the operator } \\
\text { accreditation scheme in } \\
\text { conjunction with relevant } \\
\text { training bodies. } \\
\text { - Set time frame for full } \\
\text { operator accreditation. }\end{array}$ \\
\hline
\end{tabular}


Table 5.1. (Continued) Responsibilities and Timing for the Implementation of the Regional Strategy

\begin{tabular}{|c|c|c|c|}
\hline Institution & Immediate (Within 2 years) & Mid-Term (2-5 years) & Long-Term (5-10 years) \\
\hline NGOs & $\begin{array}{l}\text { Support the policy direction and } \\
\text { training program instituted by } \\
\text { APFC and within countries. } \\
\text { Support through the provision of } \\
\text { finance, resources and personnel. } \\
\text { - Develop an NGO-level strategy } \\
\text { for Code and RIL } \\
\text { implementation. This should } \\
\text { focus primarily on small-scale } \\
\text { operations. } \\
\text { Develop training programs } \\
\text { based on the policy direction } \\
\text { that can be applied to village- } \\
\text { based operations. }\end{array}$ & $\begin{array}{l}\text { Provide training for village- } \\
\text { based programs and small } \\
\text { walkabout operations. } \\
\text { - Provide for key training staff to } \\
\text { attend the regional-level Train } \\
\text { the Trainers programs. }\end{array}$ & $\begin{array}{l}\text { Develop operator } \\
\text { accreditation training } \\
\text { through Forestry } \\
\text { Departments and training } \\
\text { bodies for application at the } \\
\text { local community level. }\end{array}$ \\
\hline $\begin{array}{l}\text { Private } \\
\text { Companies }\end{array}$ & $\begin{array}{l}\text { Adopt and implement the Code } \\
\text { of Practice for Forest Harvesting } \\
\text { in the Asia-Pacific where } \\
\text { applicable. } \\
\text { - Provide in-house training in the } \\
\text { Code's field application and } \\
\text { send key staff to regional and } \\
\text { national training programs. } \\
\text { - Work with institutional bodies to } \\
\text { look at the cost benefits that can } \\
\text { be achieved through utilisation } \\
\text { of new practices. }\end{array}$ & $\begin{array}{l}\text { Adopt and implement a } \\
\text { country-specific code when } \\
\text { developed to replace the } \\
\text { Code of Practice for Forest } \\
\text { Harvesting in the Asia-Pacific. } \\
\text { - Alter practices at all levels to } \\
\text { meet new Code guidelines. } \\
\text { - Commence the process of } \\
\text { self-auditing operations. } \\
\text { - Trial Silvicultural Prescriptions } \\
\text { with Forestry Department and } \\
\text { research bodies. } \\
\text { - Adopt the Reduced Impact } \\
\text { Harvesting Guidelines. } \\
\text { Work with Forestry Ministry } \\
\text { and training institutions to } \\
\text { develop operator accreditation } \\
\text { programs. } \\
\text { - Fund industry training body. }\end{array}$ & $\begin{array}{l}\text { - Compliance with Code } \\
\text { implementation criteria. } \\
\text { - Convert machinery fleet to } \\
\text { comply with the philosophy } \\
\text { of Reduced Impact } \\
\text { Logging. } \\
\text { - Support and undertake } \\
\text { accreditation programs } \\
\text { phasing in mandatory } \\
\text { requirements for operator } \\
\text { accreditation. }\end{array}$ \\
\hline $\begin{array}{l}\text { Research } \\
\text { Organisations }\end{array}$ & $\begin{array}{l}\text { Determination of past and } \\
\text { existing projects and } \\
\text { organisations and identification } \\
\text { of their suitability to cover } \\
\text { existing information } \\
\text { requirements. } \\
\text { - APFC ad hoc Working Group to } \\
\text { co-ordinate funding, determine } \\
\text { project structures and timing. }\end{array}$ & $\begin{array}{l}\text { Establish a set of projects } \\
\text { focused on determining } \\
\text { impacts on various second- } \\
\text { ary production forests and } \\
\text { the development of forest } \\
\text { type-specific silvicultural } \\
\text { prescriptions. } \\
\text { - Establish projects or harness } \\
\text { existing projects to determine } \\
\text { the costs and benefits of } \\
\text { applying the Code and RIL in } \\
\text { different forest types. }\end{array}$ & $\begin{array}{l}\text { Commence providing } \\
\text { stakeholder bodies with } \\
\text { information on the costs } \\
\text { and benefits of application } \\
\text { of the Code. } \\
\text { - Begin to coordinate } \\
\text { research results to produce } \\
\text { Silvicultural Prescriptions } \\
\text { at a sub-regional level. } \\
\text { - Continue to examine the } \\
\text { stakeholders needs to } \\
\text { ensure that the research } \\
\text { adds value to the } \\
\text { implementation programs. }\end{array}$ \\
\hline $\begin{array}{l}\text { International } \\
\text { Donor } \\
\text { Organisations }\end{array}$ & $\begin{array}{l}\text { Publish the Regional Strategy. } \\
\text { Support the wide-scale } \\
\text { distribution of the Code and the } \\
\text { Regional Strategy to } \\
\text { stakeholder bodies in all } 29 \\
\text { APFC member countries. }\end{array}$ & $\begin{array}{l}\text { Continue to support and fund } \\
\text { regional and national-level } \\
\text { training programs. }\end{array}$ & $\begin{array}{l}\text { APFC ad hoc Working Group } \\
\text { to continue monitoring and } \\
\text { directing implementation } \\
\text { through the focal points. } \\
\text { - Support the training and } \\
\text { implementation programs. }\end{array}$ \\
\hline
\end{tabular}


Table 5.1. (Continued) Responsibilities and Timing for the Implementation of the Regional Strategy

\begin{tabular}{|c|c|c|c|}
\hline Institution & Immediate (Within 2 years) & Mid-Term (2-5 years) & Long-Term (5-10 years) \\
\hline & $\begin{array}{l}\text { Support training programs at the } \\
\text { three levels of implementation, } \\
\text { i.e. policy makers, mid-level } \\
\text { managers and supervisors/ } \\
\text { operators. } \\
\text { - Support for APFC-suggested } \\
\text { funding areas based on the } \\
\text { implementation strategy. } \\
\text { - Provide trainers from APFC } \\
\text { countries or a country with the } \\
\text { skills/expertise appropriate to a } \\
\text { certain area. } \\
\text { - Provide funding for the Code } \\
\text { implementation officer. } \\
\text { - Provide funding to the ad hoc } \\
\text { Working Group to support Code } \\
\text { implementation activities. }\end{array}$ & & $\begin{array}{l}\text { Assist with setting of } \\
\text { long-term criteria and } \\
\text { indicators. }\end{array}$ \\
\hline $\begin{array}{l}\text { All stake- } \\
\text { holders }\end{array}$ & $\begin{array}{l}\text { Work jointly to achieve Code } \\
\text { implementation. } \\
\text { - Provide input to the national } \\
\text { steering committees. } \\
\text { - The national steering } \\
\text { committee to utilise the support } \\
\text { of the APFC and the Code } \\
\text { implementation officer. } \\
\text { - Accept allocated roles within } \\
\text { the national implementation } \\
\text { strategy. } \\
\text { - Proactively participate in } \\
\text { regional and in-country } \\
\text { awareness training. } \\
\text { - Through the steering } \\
\text { committee work towards the } \\
\text { optimal allocation of resources } \\
\text { to achieve the desired } \\
\text { outcomes. }\end{array}$ & $\begin{array}{l}\text { Commence regular reporting } \\
\text { back to the national steering } \\
\text { committee to ensure that the } \\
\text { programs stay 'on track'. }\end{array}$ & \\
\hline
\end{tabular}




\section{Strategy Outcomes}

The outcomes of successfully implementing the actions of this strategy will include:

- improved standard of harvesting operations in production forests in the Asia-Pacific Region allowing sustainable forest harvesting;

- improved health and status of the residual stand and forest environment and societies dwelling in and around the forest;

- positive economic impacts at the local level resulting from increased employment, economic activity and flow on benefits;

- a sustainable and more efficient and competitive forest industry in the region which takes into consideration the social and environmental values of the forest;

- improved institutional capacity and capability of staff and workers in the forest sector in Asia-Pacific;

- enhanced understanding of the impacts of forest harvesting on different forest types, costs and benefits and effects on the societies and economies in the regions and countries where undertaken; and

- recognition of the role production forestry plays, at both the community and concession levels, in its potential to be undertaken as a sustainable land use and to assist with the prevention of further environmental degradation. 


\section{Appendix 1}

\section{Asia-Pacific Forestry Commission Member Countries}

\begin{tabular}{|c|c|c|c|}
\hline \multicolumn{2}{|c|}{ Country } & \multicolumn{2}{|c|}{ Country } \\
\hline 1. & Australia & 16. & Nepal \\
\hline 2. & Bangladesh & 17. & New Zealand \\
\hline 3. & Bhutan & 18. & Pakistan \\
\hline 4. & Cambodia & 19. & Papua New Guinea \\
\hline 5. & China & 20. & Philippines \\
\hline 6. & Fiji & 21. & Portugal \\
\hline 7. & New Caledonia (France) & 22. & Republic of Korea \\
\hline 8. & India & 23. & Samoa \\
\hline 9. & Indonesia & 24. & Solomon Islands \\
\hline 10. & Japan & 25. & Sri Lanka \\
\hline 11. & Lao P.D.R. & 26. & Thailand \\
\hline 12. & Malaysia & 27. & United States of America \\
\hline 13. & Maldives & 28. & Vanuatu \\
\hline 14. & Mongolia & 29. & Vietnam \\
\hline 15. & Myanmar & \multicolumn{2}{|c|}{ Observer member: United Kingdom } \\
\hline
\end{tabular}




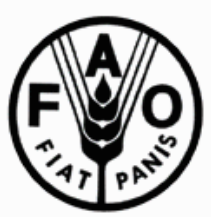

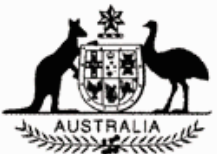
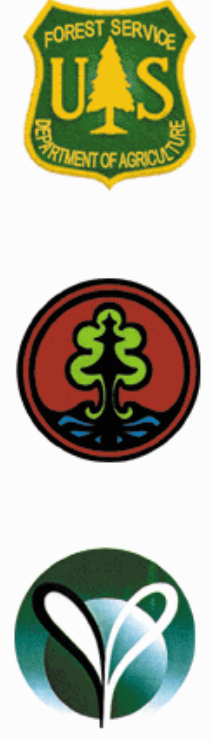

JAAKKᄆ PÜYRY

Jaakko Pöyry Consulting

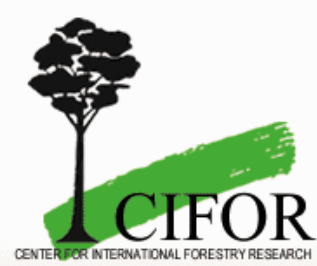

